\title{
STŘEDOVĚKÉ A NOVOVĚKÉ HRNČÍŘSKÉ PECE V ČECHÁCH - KRITICKÉ ZHODNOCENÍ VÝPOVĚDNÍCH MOŽNOSTÍ STUDIA
}

\author{
LADISLAV ČAPEK - MICHAL PREUSZ
}

\begin{abstract}
Abstrakt: Hrnčířské pece patři mezi archeologické nálezy dokládajici prímou výrobu keramiky. VČechách dosud chybi přehledová práce shrnujici všechny dosavadni archeologicky známé přiklady středověkých a raně novověkých peci a zasazující je do širšího srovnávacího evropského kontextu. Přispěvek je pokusem o zhodnocení nálezủ hrnčiřských pecí v Čechách datovaných do obdobi 13.-16./17. století. Sleduje celkovou konstrukčni podobu peci a jejich typologickou a funkčni klasifikaci. Tradični typologie jednoprostorových a dvouprostorových pecí je problematická vzhledem $k$ obtižnému prokázání charakteristického oddělení topeniště od vypalovacího prostoru pomoci dělici přepážky či roštu. Důležité je proto sledovat i termodynamické vlastnosti-tah plamene v peci. Na základě způsobu vedení plamene v peci můžeme pece rozdělit na vertikálni a horizontálni, př́padně na pece s diagonálním tahem plamene.
\end{abstract}

Klíčová slova: hrnčířské pece - typologie-jednoprostorová vertikální a horizontální pec-mladši a pozdní středověk - raný novověk - Čechy.

Medieval and modern-age pottery kilns in the Czech lands: a critical revision of the informative potential of research

Abstract: Pottery kilns count among archaeological finds evidencing the direct production of pottery. An overview summarizing all archeologically known examples of medieval and early modern-age kilns placing them in a broader comparative European context is still missing in the Czech Republic. This contribution assesses the finds of pottery kilns in the Czech lands dating from the 13th-16th/17th centuries. It examines the construction of the kilns, their typology and functional classification. The traditional typology of single-chamber and double-chamber kilns appears problematic as the existence of the characteristic separation of the furnace from the firing chamber by means of a partition or grate is difficult to prove. It is therefore important to observe also the thermodynamic properties such as the draft of the kiln. Based on the direction of the flame in the kiln, the kilns can be divided into vertical, horizontal and cross-draft kilns.

Key words: pottery kilns - typology - single-chamber vertical and horizontal kiln - early and late Middle Ages-early modern age-Czech lands.

\section{1 Úvod}

Hrnčířské pece patří, spolu s dalšími doprovodnými nálezy, mezi nejvýznamnější archeologické nálezy dokládající primární výrobu keramiky. Studium hrnčířských pecí může přispět k řešení otázek týkajících se jak specializace hrnčířské výroby, její organizace a distribuce hrnčířských výrobků, tak i transferu výrobních technologií a jejich inovací, stejně jako ke sledování socio-kulturních a obchodních kontaktů. Technické vybavení hrnčířských pecí a způsob výpalu jsou faktory, které ukazují na kvalitu keramické produkce (Vágner 2002, 309). Za hrnčířské pece považujeme objekty z trvanlivějších konstrukčních materiálů (mazanice, kámen, cihly), které mají uzavřenou nebo částečně otevřenou kupoli nebo klenbu s otvorem pro odvod kouře. $\mathrm{V}$ čele pece se nachází topný otvor, př́ípadně má pec i boční nakládací otvor. V hrnčířských pecích je možné ovlivňovat a regulovat jak tah plamene pomocí vnitřních úprav vypalovacího prostoru (tahové kanály, sokly, středové sloupy, přepážky, horizontální a vertikální rošty apod.), tak atmosféru v peci za přístupu vzduchu - oxidační výpal, nebo nepř́istupu vzduchu - redukční výpal pomocí otevírání či uzavírání kouřových otvorů v klenbách pecí (Heege 2007, 13). Oproti jiným konstrukčně jednodušším objektům, které umožňovaly výpal keramiky v ohništi, v jámě nebo v milíŕi (srov. Snášil 1970; Drews 1978-1979, 33-35; Thér 2004, 40; Varadzin 2010, 22-23), mají keramické pece nesporné výhody v lepších možnostech akumulace tepla, dále například $\mathrm{v}$ tom, že palivo není v př́mém kontaktu se vsádkou a při efektivní strategii přikládání je spotřeba paliva výrazně nižší. Pece zároveň představují zařízení, v němž lze regulací horkých plynů dosáhnout stejnoměrného výpalu keramické vsádky za vyšších teplot (srov. Weiser 2003, 19). 
S nálezy hrnčiřských pecí se setkáváme již v pravěkém a protohistorickém (anticko-provincionálním) období. Předmětem této studie jsou nálezy středověkých až raně novověkých pecí z Čech, kterým se dosud nevěnovala dostatečná pozornost. Hrnčířským pecím se archeologické bádání věnovalo především na Moravě (Nekuda 1963; 1978-1979; Zatloukal 2000; nejnověji Procházka 2015), včetně hledání etnografických paralel (Snášil 1970). V sousedních zemích se setkáváme s mnohem širším zájmem o problematiku hrnčířských pecí. Systematickému studiu s podrobným hodnocením a klasifikací nálezů hrnčířských pecí se věnují tradičně badatelé v Německu (Janssen 1985; Weiser 2003) a zásluhou A. Heegeho i v dalších západoevropských zemích - Nizozemí, Belgie, Švýcarsko, Rakousko (Heege 2007; 2009; 2013). Pro starší stř̌edověké období lze připomenout práce F. Biermanna (Biermann 1998; Biermann-Pust 2011). V Rakousku se nálezy hrnčířských pecí dlouhodobě zabývá G. Scharrerová-Liška (Scharrer 2000; 2001; Scharrer-Scharrer 2010), přehled rakouských nálezů pecí je uveden v práci A. Kaltenbergerové (Kaltenberger 2009, 250-261). V Polsku se hrnčířským pecím věnovalo především starší bádání, a to jak z archeologického (Gajewski 1959; Kwapieniowa-Walowy 1969), tak tradičně etnografického hlediska (Reinfuss 1960). Ze Slovenska lze zmínit přehledovou práci F. Kalesného (Kalesný 1993). Dosavadní nálezy pecí z oblasti Karpatské kotliny, na území bývalých Uher, včetně Slovenska, zhodnotil Z. Vágner (Vágner 2002). ${ }^{1}$

V posledních letech se věnoval otázkám hrnčířské výroby a její organizace v 6 . až 13. století v Čechách a na Moravě L. Varadzin, který se pokusil zasadit doklady hrnčířské výroby včetně nálezů pecí do širšího středoevropského kontextu (Varadzin 2010). Součástí jeho práce je katalog hrnčířských pecí, v němž poukázal na skutečnost, že nejstarší archeologicky doložené nálezy hrnčířských pecí z Čech můžeme datovat teprve až do průběhu 13. století. Principy fungování pecí a jejich typologickým vývojem se dále nezabýval. Soupis pozdně středověkých hrnčířských pecí z 13. až 15. století zahrnul do své bakalářské práce $\mathrm{M}$. Volf, který se věnoval obecně i dalším archeologickým dokladům vrcholně a pozdně středověké hrnčířské výroby, včetně topografie hrnčířských pracovišt' (Volf 2006). V posledních letech se objevily nové publikace o nálezech hrnčírských pecí, zejména z Prahy - Malé Strany (Havrda-Matějková-Tryml 2012; HavrdaMatějková 2014) a Berouna (Vyšohlíd 2015; 2015a). Nelze opomenout nově zpracované a vyhodnocené hrnčířské pece z náměstí Republiky v Praze - Novém Městě v diplomové práci V. Volfa (Volf 2014). Bohužel ani tato bezpochyby velmi kvalitní práce nebyla publikována.

Cílem tohoto příspěvku je zhodnotit dosavadní archeologicky zkoumané hrnčířské pece v Čechách, které jsou datovány do období od přelomu 12. a 13. století až po přelom 16. a 17. století. V této studii se budeme zabývat základními otázkami, které se týkají: 1) konstrukční podoby pecí, 2) principu fungováni výpalu, 3) typologického zar̆azeni, 4) datování, 5) topografie ve vztahu k osidlení a na závěr 5) organizace hrnčiřské výroby ve středověku až časném novověku. V rámci hodnocení konstrukční podoby pecí jsme si na př́kladu zahraničních analogií a etnografických paralel povšimli drobných konstrukčních detailů, které dosud unikaly pozornosti archeologů. Zejména jde o vztah topného a vypalovacího prostoru, který může vysvětlit některé způsoby fungování pecí během výpalu. Tyto drobné konstrukční detaily patří do pomyslné kategorie ,archeologie nenalézaného“.

Velká pozornost byla v zahraničí v minulosti, ale i v posledních letech věnována typologické klasifikaci středověkých a novověkých hrnčířských pecí v západní, ale i východní části Evropy (Musty 1974; Janssen 1985; Moorhouse 1981; 1987; Kalesný 1993; Guadagnin 2000; Vágner 2002; Weiser 2003; Heege 2007; 2013). Pakliže porovnáme stav výzkumu v zahraničí se situací v tuzemské archeologii, zjistíme, že typologie pecí je v našem prostředí nedostatečně propracována a jen málo studií řeší podrobně problematiku konstrukční a technicko-funkční podoby pecí a samotný princip fungování výpalu. V dosavadní typologii navíc nebyl kladen důraz na způsob, jak byl v peci tažen plamen či jak byl usměrňován. To úzce souvisí s umístěním topných otvorů, $\mathrm{s}$ tvarem a velikostí komína, ale i vnitřních dělicích přepážek a roštů, které se $\mathrm{v}$ archeologických situacích dochovávají jen velmi zř́ídka. Z tohoto pohledu jsou důležité inspirativní závěry

1 Zmíněny jsou zde pouze základní a přehledové syntetické práce. 
R. Procházky, který provedl podrobný rozbor středověkých hrnčířských pecí z Moravy a u některých pecí reinterpretoval jejich funkci a typologické zařazení (srov. Procházka 2015). Cílem tohoto článku je vytvořit podobnou klasifikaci hrnčířských pecí z Čech. Vycházíme především $\mathrm{z}$ jejich podrobného rozboru a snažíme se o jejich komparaci nejen s moravskými př́klady, ale i s př́iklady v rámci širšího kontextu střední Evropy.

\section{Přehled a rozbor hrnčírských pecí v Čechách}

Základem pro hodnocení hrnčířských pecí se stalo vytvoření deskriptivních kategorií a databáze, která umožňuje formalizované zpracování dosud nesystematicky (popisně) hodnocených př́ikladů hrnčířských pecí a jejich vzájemné srovnávání. Struktura databáze je tvořena dvěma relačně propojenými tabulkami/formuláři - první formulář Lokalita (obr. 1) obsahuje topografické informace o lokalitě, archeologickém výzkumu, nálezových okolnostech a odkazy na literaturu (nálezovou zprávu či publikaci). Druhý formulář Keramická pec (obr. 2) se pak již věnuje jednotlivým prŕíkladům pecí - je v něm zaznamenáváno následující: kategorie nálezu (pec, střepiště), typ pece (podle tradičního dělení - jednoprostorová/dvouprostorová, vertikální/horizontální), tvar pece v půdorysu, rozměry (délka/šiřka), dále popis klenby/kupole, popis stěn, včetně umístění topného či nakládacího otvoru, popis a úprava dna, přítomnost předpecní jámy. Zjištovali jsme rovněž, zda a jakým způsobem je odděleno topeniště od vypalovacího prostoru; dále zda je doložena vsádka uvnitř pece nebo v okolí pece střepiště defektní keramiky jednoznačně dokládající hrnčířskou výrobu. Řešili jsme také otázku vztahu výrobního zařízení k osídlení a zástavbě, jeho umístění v rámci vesnického či městského areálu (zda byla pec nalezena ve vnitřním

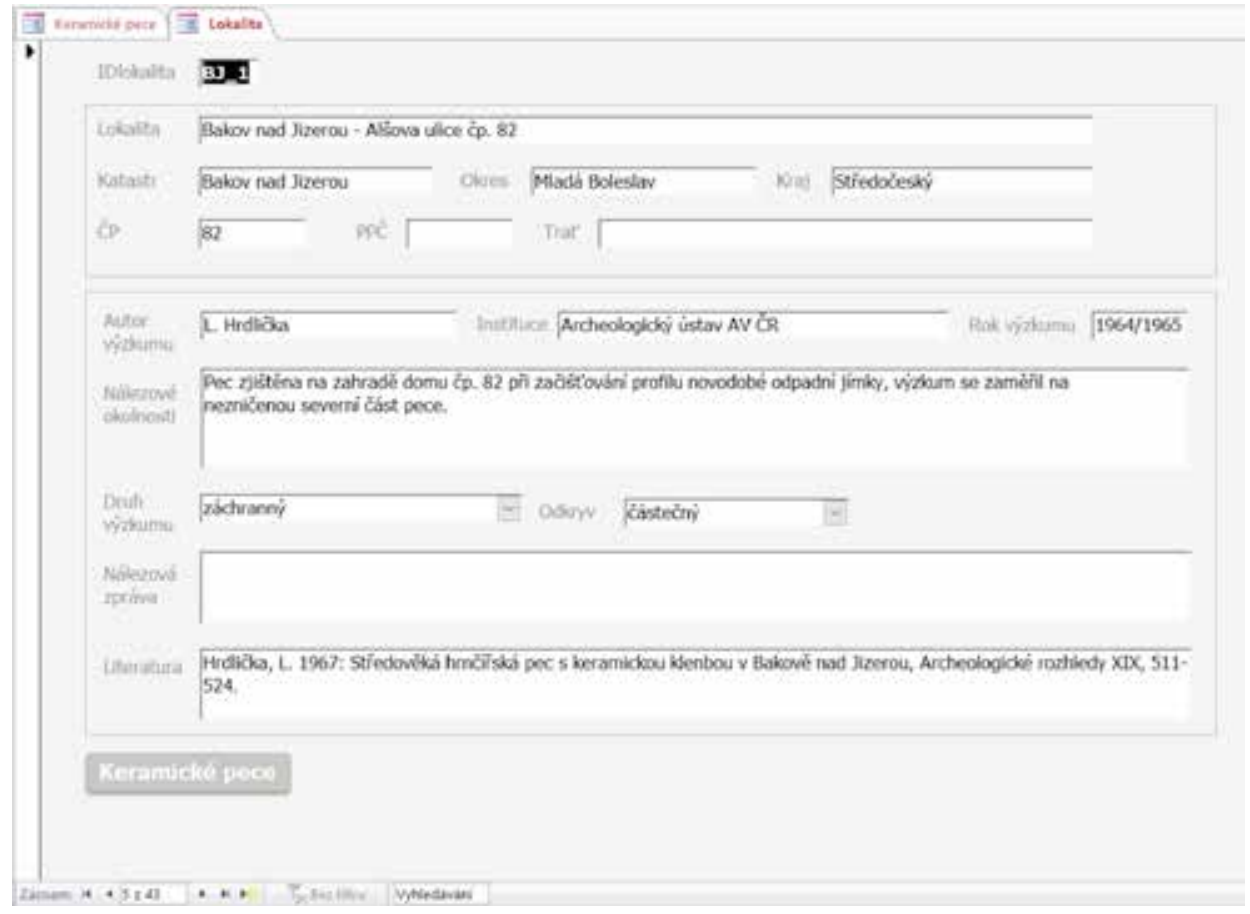

Obr. 1. Ukázka formuláře Lokalita k databázi keramických pecí.

Abb. 1. Beispiel für das Formular Fundstelle zur Datenbank Keramiköfen. 


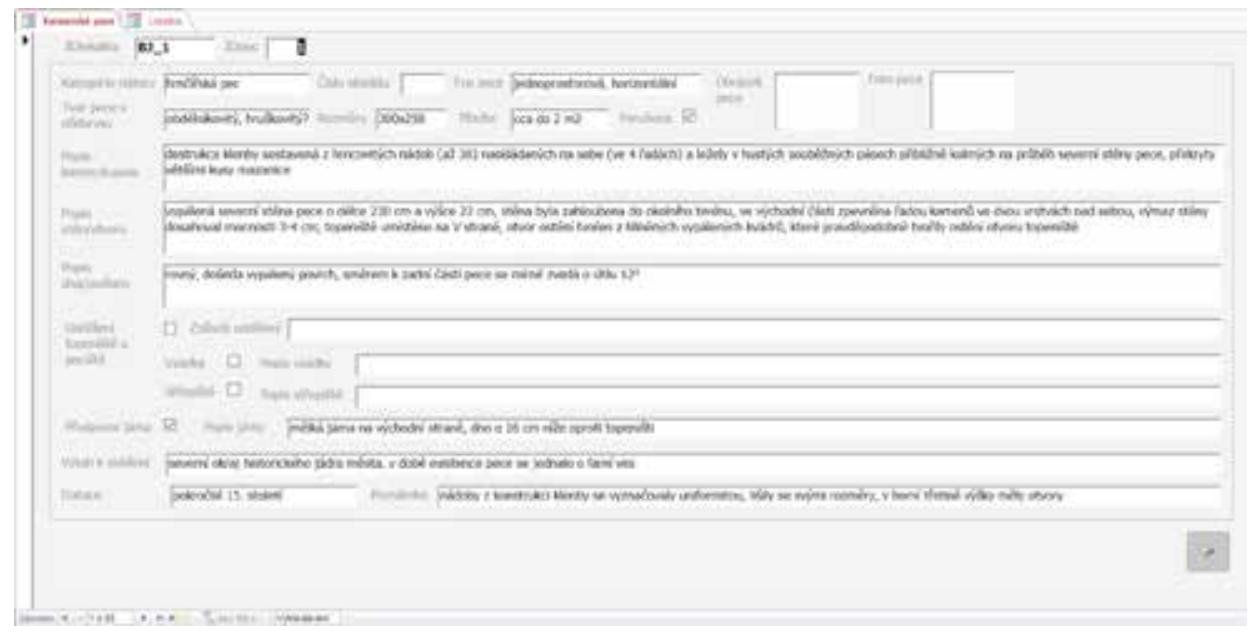

Obr. 2. Ukázka formuláře Keramická pec k databázi keramických pecí.

Abb. 2. Beispiel für das Formular Keramikofen zur Datenbank Keramiköfen.

městě nebo na předměstí). Věnujeme se i otázce datování. Databáze v současnosti obsahuje na 96 nálezů pecí (a to včetně dosud nepublikovaných př́íkladů) pocházejících z celkem 43 lokalit v Čechách. ${ }^{2}$

Databáze zahrnuje všechny archeologicky zkoumané příklady pecí. Zahrnuje i ty, které byly značně porušeny, a není možné je blíže hodnotit a klasifikovat. Řada nálezů pecí byla objevena $\mathrm{v}$ podstatě náhodně při vzorkování terénních situací a jen několik příkladů hrnčiřských pecí bylo odkryto $\mathrm{v}$ úplnosti bez výrazného porušení. $\mathrm{V}$ řadě případů narážíme na značnou fragmentárnost nálezových situací. Nutno podotknout, že i úroveň zpracování výsledků archeologických výzkumů hrnčířských pecí je značně nerovnoměrná. Některé nálezy pecí byly publikovány pouze předběžně (např. Česká Lípa), jiné pouze informativním způsobem (např. Tábor - Mikuláše z Husi čp. 44; Beroun - ul. Politických vězňů p. č. 296; Heřmaň), u jiných postrádáme klíčovou kresebnou dokumentaci pro určení typu - zejména př́ičné a podélné řezy (např. Plzeň - Lochotínská ulice) či dostatek kvalitních obrazových př́iloh (např. Horšovský Týn). V řadě případo̊ jsme proto museli přihlédnout $\mathrm{k}$ dokumentaci v nálezových zprávách, zejména těch, které jsou dnes veřejně dostupné na stránkách digitálního archivu Archeologického ústavu AV ČR, Praha, v. v. i.

\section{Topografie hrnčířských pecí a nálezový kontext}

V rámci hodnocení hrnčířských pecí jsme sledovali jejich topografii a umístění ve vztahu k sídelnímu areálu. Distribuční mapa ukazuje nálezy hrnčířských pecí v rámci Čech a jejich četnost $\mathrm{v}$ rámci jednotlivých lokalit. Zároveň odráží i současný stav výzkumu pecí v jednotlivých regionech (obr. 3). Větší počet nálezů je registrován ve středních a severovýchodních Čechách. Z geografického hlediska se hrnčířská výroba koncentruje na okrajích nížinné oblasti Polabí, dále $\mathrm{v}$ oblasti pahorkatin a vrchovin a v blízkosti nebo př́imo v regionálních městských centrech. Známe jak lokality, v nichž jsou doloženy jedna až dvě hrnčířské pece, tak místa, kde

2 Pro srovnání databáze archeologických nálezů hrnčířských pecí z oblasti Německa, Belgie, Nizozemí, Rakouska a Švýcarska, vytvořená v letech 2005 až 2007 A. Heegem, obsahuje celkem 316 nálezů hrnčiřských pecí z 15. až 20. století. Největší počet nálezů (celkem 245 ) pochází z oblasti Německa (Heege 2013, 279). 


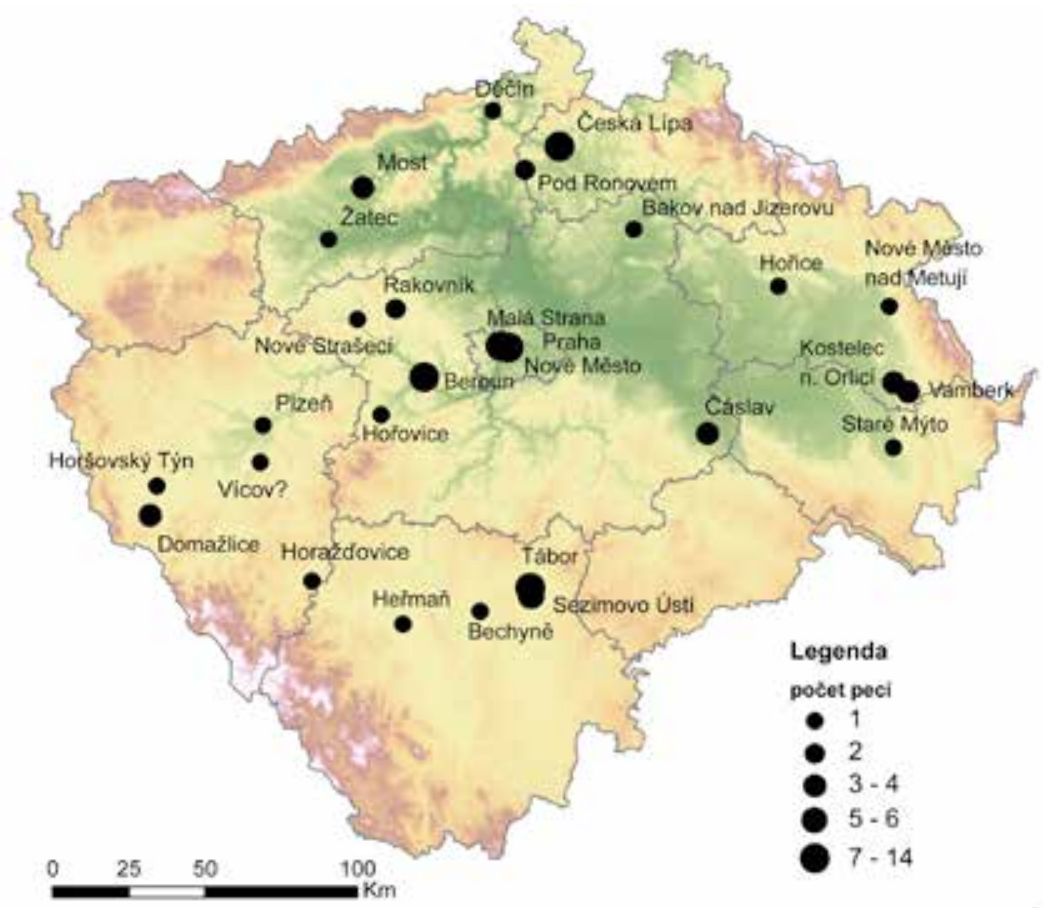

Obr. 3. Mapa hrnčířských pecí ze 13.-16./17. století v Čechách. Autor L. Čapek.

Abb. 3. Karte mit Keramiköfen aus dem 13.-16./17. Jhdt. in Böhmen. Erstellt von L. Čapek.

byl objeven větší počet pecí. ${ }^{3}$ Nejvíce pozůstatků pecí pochází z České Lípy (14 objektů pecí!), Berouna - Hrnčířského předměstí (10 pecí), dále pak z Prahy - Malé Strany a Nového Města pražského (nám. Republiky). Větší počty pecí byly nalezeny v Táboře, Sezimově Ústí a Domažlicích. V těchto výrobních centrech některé pece fungovaly pospolu ve stejném období (napřs. na náměstí Republiky v Praze - Novém Městě, v Sezimově Ústí, Domažlicích), nebo s větším časovým odstupem a bez přímé návaznosti (Praha - Malá Strana). Jinde je doložena časová návaznost pecí, kdy starší pec je porušena založením mladší pece ve vzájemné superpozici, např. Česká Lípa (Gabriel 1979, 262), Tábor - náměstí Mikuláše z Husi čp. 44 (Krajíc 2007, 152-153), Beroun - ulice Politických vězňů p. č. 296 (Benková 2014, 940).

Co se týče prostorového vztahu hrnčiřských pecí a jejich umístění v rámci sídelního areálu, setkáváme se s nálezy jak ve vnitřním městě (uvnitř hradeb), tak na předměstích (tab. 1). Větší počet nálezů pecí z Prahy nadhodnocuje počet př́ikladů nalezených v zastavěné části města vůči nálezům na předměstích, kam bylo hrnčířské řemeslo v pozdním středověku nejčastěji přesouváno kvůli protipožárním opatřením a snadnější dostupnosti vody či surovin (např. Sezimovo Ústí - levobřežní předměstí; Beroun - Hrnčířské předměstí; Domažlice - Hořejší předměstí apod.). Pouze několik příkladů pecí bylo nalezeno v rámci předlokačního osídlení v okolí církevních staveb (Česká Lípa - u kostela sv. Máŕí Magdalény, ${ }^{4}$ Most - u kostela Sv. Václava) či v místě pozdější zaniklé městské lokace (Staré Mýto). Pouze několik pecí bylo nalezeno v areálech vsí (Kostelec nad Orlicí, Vícov, Heřmaň) či vesnicích, jež se později rozvinuly v poddanská města (Bakov nad Jizerou).

3 Větší počet nálezů pecí pochází z míst, kde bylo zkoumáno i širší okolí nebo celé hrnčířské pracoviště, tedy z plošných archeologických výzkumů. Při záchranných akcích byla zpravidla zjištěna pouze jediná pec, která však mohla být součástí většího areálu s dalšími pecemi.

4 Později byl hrnčiřský areál kolem kostela sv. Máří Magdalény začleněn do struktury předměstí (Gabriel-Smetana 1980, obr. 2). 


\begin{tabular}{|l|c|}
\hline Areál & Počet pecí \\
\hline vnitřní město/zastavěná část & 35 \\
\hline předměstí & 25 \\
\hline předlokační osídlení & 8 \\
\hline zaniklá městská lokace & 2 \\
\hline vesnice & 7 \\
\hline
\end{tabular}

Tab. 1. Vztah nálezů hrnčířských pecí $\mathrm{k}$ sídelnímu areálu. Tab. 1. Bezug der Töpferöfenfunde zum Siedlungsareal.
Většina nálezů hrnčiřských pecí pochází ze záchranných výzkumů, při nichž došlo k odkrytí jejich reliktů, avšak nebylo zkoumáno jejich bezprostřední okolí. Výjimečně bylo doloženo vedle hrnčířské pece i střepiště, které jednoznačně dokládá hrnčiřskou výrobu (srov. Zatloukal 2000, 62). Známe i lokality, kde je doloženo pouze střepiště, bez nálezu keramické pece (Levín, Hořovice). Pouze několik příkladů hrnčířských pecí pochází přímo z plošných výzkumů hrnčířských pracovišt', kde kromě pecí a střepišst' byly nalezeny další doklady primární hrnčířské výroby, jako deponie hrnčířských surovin (jílů a ostřiv), sklípky na zrání jílů a prostory pro skladování hotových výrobků. Mezi těmito situacemi vyniká systematický odkryv tří zaniklých hrnčířských usedlostí na levobřežním předměstí Sezimova Ústí (Richter-Krajíc 2001, 53-62, 65-74). Další hrnčířské areály byly odkryty při záchranných a předstihových výzkumech na Hořejším předměstí v Domažlicích (Procházka 1983, 6-8), ve Vlašské ulici v Praze na Malé Straně (Havrda-Matějková 2014), na náměstí Republiky v Praze - Novém Městě (Kašpar-Žegklitz 2009, 79-83; Volf 2014) a na tzv. Hrnčířském předměstí v Berouně (Vyšohlíd 2015; 2015a; Benková 2014).

\section{Půdorysná a konstrukční podoba pecí}

Pouze v několika případech byly hrnčířské pece v Čechách odkryty kompletně v celém půdorysu, který umožňuje rekonstrukci jejich tvaru (obr. 4). Řada nálezů pecí byla zkoumána vzorkováním na hraně výkopu či v rámci plošně omezeného odkryvu. Další byly poničeny mladšími situacemi, které narušily jejich původní podobu.

Ve většině př́ípadů je tvar pecí v půdoryse oválný/vejčitý, dále pak kruhový, hruškovitý, výjimečně podkovovitý, obdélníkovitý a obloukovitý (obr. 5). Již z hlediska hodnocení rozměrů jejich půdorysů může vyplynout základní rozdělení na pece vertikální (s vertikálním tahem plamene), které mají zpravidla kruhový či mírně oválný tvar, u něhož nejsou pozorovány výrazné rozdíly mezi délkou a šiřkou pece, a pece horizontální (s horizontálním tahem plamene), které mají spíše protáhlý hruškovitý a oválný tvar, jejichž délka je větší než šířka, a to přibližně v poměru 1 : 2 (srov. Procházka 2015, 218).

U pecí se zjištěnými či rekonstruovanými rozměry byl sledován index poměru šířky a délky na bodovém grafu proloženém regresní přímkou (obr. 6). Ve spodní části grafu se objevily pece s menšími rozměry, podobného délko-šířkového indexu, naopak v horní části grafu vpravo se nacházejí pece s velkými rozměry, u nichž index délky dosahuje vyšších hodnot než index šířky. Lineární regrese ukazuje závislost hodnot délky a šířky a trend pozvolného zvětšování velikosti pecí datovaných do průběhu pozdního středověku. Zvětšování kapacity pecí je obecně vysvětlováno potřebou dosáhnout vyššího objemu keramické produkce, přitom délka pecí nepřekročila hranici 4 metrů (srov. Procházka 2015, 219). Podle rozměru půdorysu a výšky pece je možné stanovit rámcový odhad kapacity, resp. objemu, pecí pro vložení keramické vsádky (např. Kaltenberger 2009, 263).

Nyní se podíváme na celkovou konstrukční podobu středověkých pecí na základě podrobného rozboru publikovaných př́kladů. $\mathrm{V}$ další části textu pro přehlednost vynecháváme odkazy na literaturu, jež je uveřejněna $v$ kompletní podobě na konci práce.

Většina pecí byla zahloubena pod úroveň původního terénu. Základ nejstarších pecí z 13. století byl jednoduše modelován z hlíny bez ztužujících konstrukcí. Od konce 14. století se objevují základy pecí z trvanlivějších materiálů, např́íklad z lomového kamene (Praha - Nové Město, náměstí Republiky, pec č. II) nebo z kombinace kamenů a cihel se spárami vymazanými jílovitou hlínou (Plzeň - Lochotínská ulice; Beroun - Hrnčířské předměstí; Praha - Nové Město, 


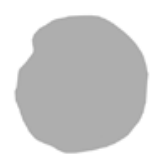

Česká Lípa č.2/1

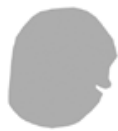

Praha -

Malá Strana

s. IX

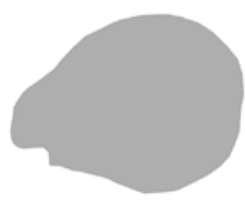

Sezimovo Ústi usedlost XII

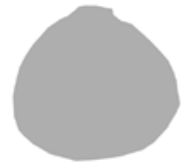

Tábor nad Lužnici

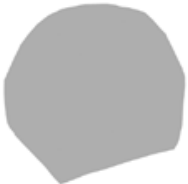

Praha - Nové Město nám. Republiky č. II
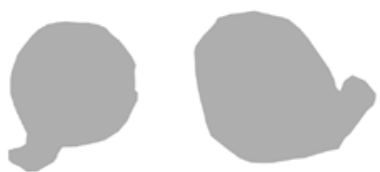

Sezimovo Ústí usedlost XII

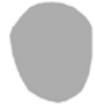

Praha Malá Strana s. IX

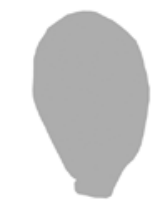

Praha -

Malá Strana

Vlašská ul, v. 04

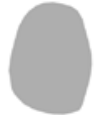

Kostelec

n. Orlicí č.2

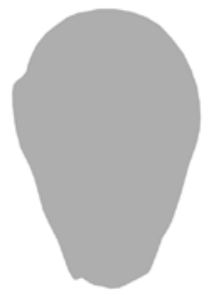

Česká Lípa, č. 3/1

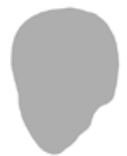

Kostelec

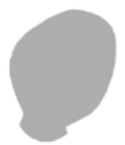

Staré Mýto

n. Orlicí č. 1

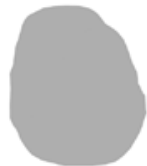

PIzeň -

Lochotín

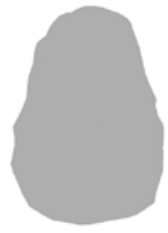

Praha - Nové Město nám. Republiky, Č. VII

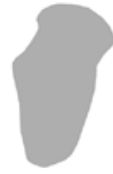

Kostelec Praha n. Orlicí č. 3 Malá Strana Malostranské nám. č. 8

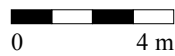

Obr. 4. Srovnání velikosti půdorysu u kompletně odkrytých hrnčířských pecí. Autor L. Čapek. Abb. 4. Vergleich der Grundrissgrößen bei komplett freigelegten Töpferöfen. Autor L. Čapek.

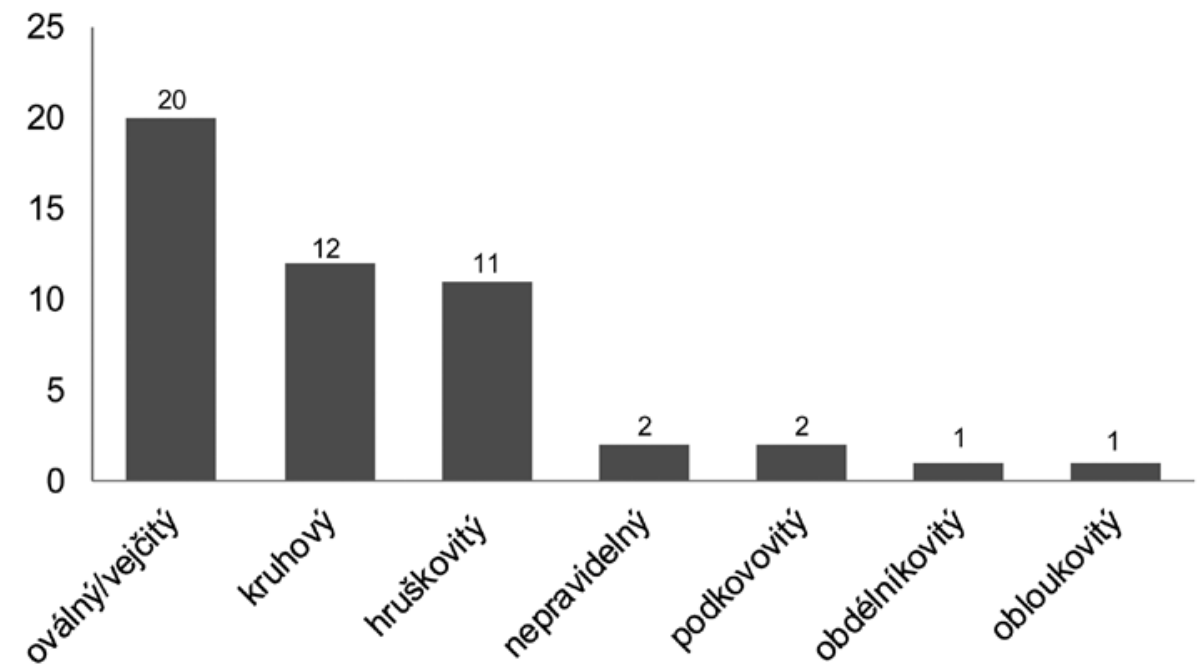

Obr. 5. Graf zastoupení hrnčířských pecí podle tvaru v půdoryse.

Abb. 5. Diagramm des Keramikofenvorkommens gemäß der Grundrissform. 


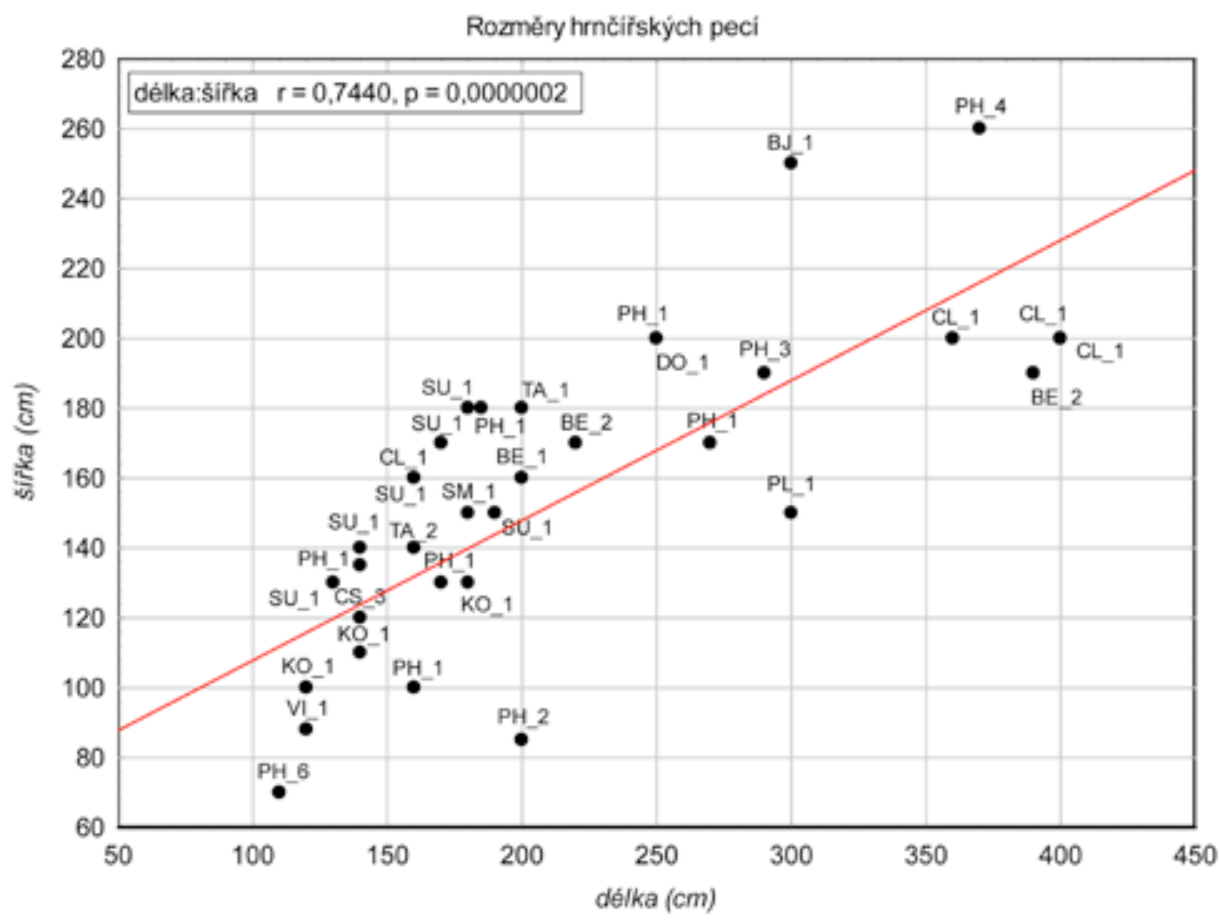

Obr. 6. Liniový graf zobrazující závislosti rozměrů (délky-šǐřy) hrnčířských pecí. BE-1 - Beroun, Česká ulice čp. 56; BE-2 - Beroun, Hrnčířské předměstí; BJ-1 - Bakov nad Jizerou, CL-1 - Česká Lípa; CS-3 - Čáslav, Jeníkovská ulice; DO-1 - Domažlice, Hořejší předměstí; KO-1 - Kostelec nad Orlicí - cihelna; PH-1 - Praha - Nové Město, náměstí Republiky, Truhlářská ulice; PH-2 - Praha - Malá Strana, Hellichova ulice; PH-3 - Praha - Malá Strana, Malostranské náměstí čp. 258; PH-4 - Praha - Malá Strana, Vlašská ulice čp. 355; PH-6 - Praha - Malá Strana, Valdštejnské náměstí; PL-1 Plzeň, Lochotínská ulice čp. 26; SM-1 - Staré Mýto; SU-1 - Sezimovo Ústí; TA-1 - Tábor - Sídliště nad Lužnicí; TA-2 - Tábor, náměstí Mikuláše z Husi čp. 44. Autor L. Čapek.

Abb. 6. Liniendiagramm mit Darstellung der Abhängigkeit der Abmessungen (Längen-Breiten) der Töpferöfen. BE-1 Beroun, Česká-Str. Nr. 56; BE-2 - Beroun, Töpfervorstadt; BJ-1 - Bakov nad Jizerou, CL-1 - Česká Lípa; CS-3 - Čáslav, Jeníkovská-Str.; DO-1 - Domažlice, Obere Vorstadt; KO-1 - Kostelec nad Orlicí - Ziegelfabrik; PH-1 - Prag - Neustadt, Platz der Republik, Truhlářská-Str.; PH-2 - Prag - Kleinseite, Hellichova-Str.; PH-3 - Prag - Kleinseite, Kleinseitner Ring Nr. 258; PH-4 - Prag - Kleinseite, Vlašská-Str. Nr. 355; PH-6 - Prag - Kleinseite, Waldsteinplatz; PL-1 - Pilsen, Lochotínská-Str. Nr. 26; SM-1 - Staré Mýto; SU-1 - Sezimovo Ústí; TA-1 - Tábor - Siedlung an der Lainsitz; TA-2 - Tábor, Nikolaus von Hus-Platz Nr. 44. Erstellt von L. Čapek.

náměstí Republiky, pec č. VII). Setkáváme se i s nálezem pece, jejíž vnější plášt’ byl tvořen kamennou podezdívkou a vnitřní konstrukce byla vystavěna $\mathrm{z}$ cihel s vrstvou hliněného omazu (Beroun - ulice Politických vězňů p. č. 296). Od konce 15. a zejména v průběhu 16. a 17. století se objevuje zdění základů pecí z cihel (např. Praha - Nové Město, náměstí Republiky, pec č. IV; Tábor - Mikuláše z Husi čp. 44; Beroun - Česká ulice čp. 56; Beroun - ulice Politických vězňů p. č. 296).

Dno pecí bylo mírně či více zahloubeno do okolního terénu. Bylo tvořeno udusanou hlínou, pečlivě vymazáno, někdy s doklady výrazného propálení. K vyrovnávání podlah se používaly vrstvy písku (Domažlice - Hořejší předměstí, pec č. 1), úlomky kamenů, napřs. opuky (Nové Strašecí), čediče (Česká Lípa), diabasu (Praha - Malá Strana, Valdštejnské náměstí), břidlicových destiček (Praha - Malá Strana, Hellichova ulice), nebo byly na dně nasypané keramické zlomky, které tvořily izolační vrstvu (Sezimovo Ústí - usedlost XII). Výjimečně se setkáváme s úpravami dna pomocí plochých kamenů (Horšovský Týn) nebo říčních oblázků (Beroun - Hořejší předměstí, č. s. j. 8-034). Na dnech se často nacházejí uhlíky, které pocházejí z nevymeteného 
popela. V 16. století nahradila hliněné dno pecí podlaha z cihel položených na plocho (Tábor Mikuláše z Husi čp. 44; Beroun - Česká ulice čp. 56; Beroun - Hrnčířské předměstí, č. s. j. S10/0-023; Beroun - ulice Politických vězňů p. č. 296). Nejsou výjimkou ani doložené opravy (reparace) podlah (Praha - Nové Město, náměstí Republiky, pec č. VI; Sezimovo Ústí - usedlost X, pec 4a a usedlost XIII; Beroun - Hrnčířské předměstí, č. s. j. S8/8-034, Beroun - ulice Politických vězňů p. č. 296).

Stěny pecí byly hliněné, vyztužené dřevěným proutěným výpletem. Pozůstatky po otiscích prutů se dochovaly $\mathrm{v}$ mazanici nebo prímo kolem obvodu dna pece $\mathrm{v}$ podobě kůlových jamek (Česká Lípa, pec č. 2/1; Praha - Nové Město, Truhlářská ulice čp. 1518/II). Konstrukce hliněných stěn byla omazána, síla omazu se nejčastěji pohybovala kolem $10 \mathrm{~cm}$. Hliněná konstrukce stěn je doložena od 13. až do 15. století (Česká Lípa; Kostelec nad Orlicí; Domažlice). Později je doloženo zpevňování stěn na bocích kameny (Sezimovo Ústí - usedlost X, pec 4a) či cihlami (Sezimovo Ústí - usedlost XII). Od 15. století tvořily vnitřní prostor stěn pecí cihlové vyzdívky (Praha - Nové Město, náměstí Republiky, pec č. I a VII; Domažlice - Hořejší předměstí, pec č. 1). Od 16. století je doložena i celá konstrukce stěn pece z cihel (Beroun - Česká ulice čp. 56; Beroun - Hrnčířské předměstí; Tábor - náměstí Mikuláše z Husi čp. 44; Bechyně, čp. 18), nebo ze smíšeného zdiva (Praha - Malá Strana, Vlašská ulice; Praha - Nové Město, náměstí Republiky, pec č. VIII; Praha - Nové Město, Jindřišská ulice; Beroun - Hrnčířské předměstí, pec č. s. j. S8/8-034; Chomutov, obj. č. 5). Z vnějšku byly cihlové stěny pece zpravidla omazány hlínou.

Ve stěnách pece se nacházel topný otvor, často zpevněný ostěním z kamenů a později z cihel. Setkáváme se i s jeho přiklopením kamennou deskou (Sezimovo Ústí - usedlost X, pec 4b). Výjimečně byly doloženy dva protilehlé topné otvory př́istupné z předpecních jam - Sezimovo Ústí - usedlost X, pec $4 \mathrm{~b}$. Pouze u pece, která byla objevena na Sídlišti nad Lužnicí v Táboře, je doložen ve stěně pece i druhý boční otvor, který byl interpretován jako nakládací, a byl rovněž uzavřen plochým kamenem. Vsádka se u většiny pecí zřejmě nakládala otvorem shora. Při nedávném výzkumu hrnčířských pecí v ulici Politických vězňů v Berouně byla dokonce odkryta pec se třemi topnými otvory.

Kupole u pecí byla hliněná. To dokládají otisky mazanice s proutěným výpletem. Ve vzácných př́ípadech se objevuje více vrstev výmazů stěn kupole, jako v př́ípadě pece z Tábora - Sídliště nad Lužnicí, kde byly doloženy tři vrstvy vymazávek na vnitřní stěně kupole. V Čechách se setkáváme více s pecemi s keramickou klenbou sestavenou z keramických nádob posléze omazaných hlínou - Bakov nad Jizerou, Plzeň - Lochotínská ulice, Horšovský Týn, Česká Lípa, Nové Strašecí, Rakovník, Žatec, Praha - Malá Strana, Malostranské náměstí čp. 258. Ve druhé polovině 16. století byly rozšířeny cihlové klenby, jako např́íklad v České ulici čp. 56 nebo v ulici Politických vězňů p. č. 296 v Berouně.

U žádného z př́íkladů hrnčiřských pecí nebyl jednoznačně doložen komín. Plameny byly v peci regulovány pomocí jednoho či více otvorů-kouřovodů v klenbě (kupoli) pece, anebo byly plameny rovnoměrně rozděleny pomocí vnitřních piliřků sestavených z cihel (Bakov nad Jizerou?; Praha - Nové Město, náměstí Republiky, pec č. II) nebo z opakovaně používaných nádob (Praha - Nové Město, náměstí Republiky, pec č. VII).

Před pecemi, před ústím topného otvoru, se nacházely oválné předpecní jámy podlouhlého tvaru, které umožňovaly př́stup k topeništi.

\section{Typologie hrnčířských pecí}

Typologie středověkých hrnčířských pecí je v Čechách nedostatečně propracována, podíváme-li se na situaci v zahraničí, zejména u př́kladů pecí z německého či rakouského prostředí (Weiser 2003, 19-21; Heege 2007; 2013; Scharrer 2000; Kaltenberger 2009, 251-252). V německých zemích jsou stř̌edověké hrnčířské pece rozdělovány na základě způsobu členění vnitřního prostoru (uspořádání topeniště a vypalovací komory) na jednokomorové pece (Einkammeröfen), kde je vsádka v přímém kontaktu s palivem, a dvoukomorové pece (Zweikammeröfen), u nichž je vsádka od paliva oddělena. Další vymezení spočívá ve způsobu vedení plamene. Pokud plamen 
stoupá z topeniště do vypalovací komory kolmo vzhůru k otvoru pro odvod kouře, označují se tyto pece jako stojaté (stehende Öfen). Pokud plamen v peci naopak prostupuje z topeniště do vypalovacího prostoru umístěného za ním přibližně ve vodorovném směru, označují se za ležaté pece (liegende Öfen). Horizontální tah umožňuje otvor umístěný na druhé straně ve stěně (kupoli) pece či komín. Zvláštní kategorii pak představují pece s diagonálním tahem plamene, kdy plamen stoupá šikmo či skokově vzhůru, což je způsobeno zapuštěním pece do svahu nebo členěním jejího dna pomocí středového soklu. Další dělení dvoukomorových pecí na jednotlivé subtypy spočívá v konstrukci dělicí přepážky či roštu. Vyděluje se zde typ hliněného roštu se štěrbinovitými průduchy (Lochtenne) a typ s hliněným, paprsčitě uspořádaným roštem (Schlitztenne). Oba typy roštů umožňovaly kontrolovaný průchod plamene a jeho rovnoměrné rozdělení ve vypalovacím prostoru. Řešeno bylo také, jakým způsobem byl rošt upevněn, např́klad zda se nacházel na středovém sloupu (Mittelsäule) či hliněném jazyku (Ofenzunge), zde zpravidla šlo o výměnný rošt z plochých kamenných destiček nebo cihel.

Typologii pecí rozpracovanou A. Heegem (2007) převzal pro klasifikaci moravských nálezů středověkých pecí R. Procházka (2015). Obdobnou, byt' poněkud zjednodušenou, typologii používá i Z. Vágner pro hodnocení hrnčířských pecí z oblasti Karpat (Vágner 2002). Zcela jiná je např́iklad typologie pecí z Velké Británie, kde důležitým kritériem je počet a umístění otvorů pro odvod kouře (Musty 1974). Pro hodnocení hrnčířských pecí z Čech jsme se přiklonili k německé typologii pecí převzaté R. Procházkou (2015), aby lépe vyniklo srovnání mezi Čechami a Moravou. Je však nutné upozornit na dvě terminologické odlišnosti. Místo německého a moravského označování pecí jako jednokomorové či dvoukomorové používáme v české literatuře zavedený pojem jednoprostorová a dvouprostorová pec (srov. Varadzin 2010). Místo poněkud kostrbatého německého překladu stojaté a ležaté pece uvádíme pojmy vertikální a horizontální pec. Nutno podotknout, že na základě kusých informací o archeologicky zkoumaných pecích, bylo typologické zařazení výrobních zařízení velmi nesnadné a v řadě př́ípadů značně komplikované. Bohužel jsme odkázáni na stav terénní dokumentace rozdílných kvalit s popisem nálezových situací. U některých pecí postrádáme podélný řez (profil) po celé délce pece, včetně předpecní jámy. Ten je nutné z hlediska správné funkční a typologické klasifikace považovat za klíčový (srov. Heege 2007, 2).

Na základě typologického rozboru můžeme větší skupinu pecí přiřadit ke dvěma hlavním typům (tab. 2), a to: jednoduchým jednoprostorovým pecím s vertikálním tahem plamene - typ la. Menší skupina pak náleží k jednoprostorovým horizontálním pecím s nečleněným dnem - typ $2 a$. Pouze čtyři př́klady, byt's určitými výhradami, můžeme zařadit k typu $2 c$-jednoprostorovým diagonálním pecím, s předpokládaným diagonálním tahem plamene a výrazně šikmým dnem či dnem členěným soklem na více zahloubený topný prostor a vyvýšený vypalovací prostor. U žádné z českých pecí se nedochoval hliněný rošt. S výhradami můžeme pouze jeden př́íklad pece ztotožnit s typem $2 b$ - se středovým soklem (jazykem), rozdělujícím topný prostor na dva kanály, které usměrňovaly tah plamene a jež v principu mohly nést rošt.

Dělení na další subtypy spočívá v doložení existence členění vnitřního prostoru horizontálních pecí. Zcela výjimečně máme doloženu pec se stř̌edovou přepážkou - typ $2 b$. Druhou skupinu tvoří jednoprostorové horizontální pece s dělicími sloupky či pilířky - typ $2 d$.

Do typologie jsme nezařadili tzv. polní pece, jejichž existence se u nás předpokládá $\mathrm{v}$ raném středověku (srov. Varadzin 2010, 23), nebo tzv. milířovité pece. U milířovitých pecí byl princip výpalu obdobný jako u jednoprostorových vertikálních pecí. Liší se pouze tím, že pece jsou založeny na povrchu terénu nebo jen mělce zahloubeny a samotná konstrukce pece připomíná milír̆, tedy zařízení s dočasnou izolační strukturou. Užití milířovitých pecí je doloženo v etnografii (Snášil 1970; Scheufler 1972, 66), zatímco archeologicky jsou obtížně prokazatelné. V Čechách nebyl dosud doložen jediný příklad, a to včetně pecí z Domažlic, které byly mylně považovány za milířovité pece (Procházka 1983, 8). Jak polní, tak i milířovité pece přitom mohly dosahovat srovnatelných hodnot výpalu jako jednoprostorové vertikální pece a v některých prŕípadech dosáhnout i teploty do $1000^{\circ} \mathrm{C}$ (srov. Snášil 1970, 328-329; Drews 1978-1979, 33-35; Böttcher-Böttcher 1997, 88; Thér 2004, 40, 65; např. Varadzin 2010, 27-29; Heege 2007, 12; 
Biermann-Pust 2011, 137-160). V literatuře byly diskutovány i tzv. chlebové pece, někdy zaměňované za hrnčířské a naopak (Michna 1970, 68-81; Měřínský 1983, 45-46; Zatloukal 2000, 62; Měchurová-Zalabák-Čejka 1992, 211). K jejich záměně může dojít při srovnání s jednoduchými jednoprostorovými vertikálními pecemi, a to $\mathrm{v}$ prŕípadě, kdy chybí obslužný prostor v podobě předpecní jámy (Procházka 2015, 215).

Srovnávací tabulka ukazuje přehled typologicky zařazených pecí a srovnání nálezů pecí z Čech s př́iklady z Moravy. Mezi oběma regiony se ukazují výrazné rozdíly, zejména v zastoupení jednotlivých typů (tab. 2). Podívejme se nyní konkrétněji na jednotlivé př́iklady.

\begin{tabular}{|c|c|c|c|}
\hline Typ & Popis & Čechy & $\begin{array}{c}\text { Morava } \\
\text { (podle Procházka 2015) }\end{array}$ \\
\hline 1a & $\begin{array}{l}\text { jednoduchá jednoprostorová } \\
\text { vertikální pec }\end{array}$ & $\begin{array}{l}\text { Beroun - ul. Politických vězňů, čp. } \\
\text { 296; Česká Lípa (č. 2); Domažlice - } \\
\text { Hořejší předměstí; Kostelec n. Orlicí } \\
\text { (č. 1-2); Praha - nám. Republiky (č. V, } \\
\text { VI); Staré Mýto (č. 1); Tábor - Miku- } \\
\text { láše z Husi čp. 44; Tábor - Sídliště nad } \\
\text { Lužnicí; Sezimovo Ústí (usedlost VIII, } \\
\text { 4a, 4b, XIII) }\end{array}$ & $\begin{array}{l}\text { Kroměříž - Milíčovo nám.; } \\
\text { Loštice (?); Mohelnice; Opa- } \\
\text { va - Hradecká ul. (též 2a?); } \\
\text { Velké Heraltice }\end{array}$ \\
\hline $1 b$ & $\begin{array}{l}\text { jednoprostorová pec se středo- } \\
\text { vým sloupem/dělicí přepážkou }\end{array}$ & Kostelec n. Orlicí (č. 3) & Kostelec u Jihlavy \\
\hline $1 \mathrm{c}$ & $\begin{array}{l}\text { dvouprostorová vertikální pec } \\
\text { s vypalovacím otvorem a děli- } \\
\text { cím prvkem (roštem) s průduchy }\end{array}$ & & $\begin{array}{l}\text { Staré Město - Na kostelíku; } \\
\text { Uherské Hradiště - Sady; } \\
\text { Znojmo - Sokolská ul. }\end{array}$ \\
\hline $1 d$ & $\begin{array}{l}\text { dvouprostorová vertikální pec } \\
\text { s axiálním jazykem a paprsčitým } \\
\text { dělicím prvkem (roštem) }\end{array}$ & & Ivančice \\
\hline $2 \mathrm{a}$ & $\begin{array}{l}\text { jednoprostorová horizontální } \\
\text { pec s nečleněným vypalovacím } \\
\text { prostorem }\end{array}$ & $\begin{array}{l}\text { Bakov nad Jizerou; Beroun - Česká } \\
\text { ul. čp. 56; Horšovský Týn; Chomutov; } \\
\text { Plzeň - Lochotínská ul.; Praha - Malá } \\
\text { Strana, Hellichova ul., Malostranské } \\
\text { nám. čp. 258; Praha - Nové Město, } \\
\text { nám. Republiky (č. I?, III, IV); Sezi- } \\
\text { movo Ústí - usedlost XII }\end{array}$ & $\begin{array}{l}\text { Dambořice (?); Moravské } \\
\text { Budějovice; Želechovice }\end{array}$ \\
\hline $2 b$ & $\begin{array}{l}\text { jednoprostorová horizontální } \\
\text { pec se středovým jazykem }\end{array}$ & Vícov? & $\begin{array}{l}\text { Brno - Kapucínské nám.; } \\
\text { Kroměříž - Milíčovo nám.; } \\
\text { Jihlava - Křížová ul.; Mstěni- } \\
\text { ce; Staré Město - Na dvorku }\end{array}$ \\
\hline $2 \mathrm{c}$ & $\begin{array}{l}\text { jednoprostorová diagonální pec } \\
\text { se členěným dnem pomocí soklu }\end{array}$ & $\begin{array}{l}\text { Beroun (č. 8/8-034); Česká Lípa (č. 1, } \\
\text { 3, 5, 7); Praha - Malá Strana, Vlašská } \\
\text { ulice (v-04); Praha - Nové Město, } \\
\text { nám. Republiky (č. VII) }\end{array}$ & \\
\hline $2 \mathrm{~d}$ & $\begin{array}{l}\text { jednoprostorová horizontální } \\
\text { pec s dělicími sloupky/pilířky }\end{array}$ & 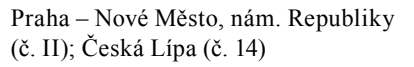 & \\
\hline
\end{tabular}

Tab. 2. Srovnávací tabulka typologie hrnčířských pecí z Čech, doplněna o pece z Moravy. Podle Procházka 2015.

Tab. 2. Vergleichstabelle der Typologie böhmischer Töpferöfen, ergänzt um Öfen aus Mähren. Nach Procházka 2015.

\subsection{Jednoprostorové vertikální pece (typ 1a)}

Jednoprostorová vertikální pec představuje nejjednodušší konstrukční typ pece kruhového nebo mírně oválného půdorysu, jejíž rozměry se nejčastěji pohybují okolo $1,6 \times 1,4$ metru. Tyto pece měly nejčastěji hliněnou kupoli, v jejímž nejvyšším vrcholu se nacházel otvor pro odvod kouře, který je v peci tažen v kolmém (vertikálním) směru. $Z$ jedné strany se ve stěně 
pece nacházelo topeniště, které je obvykle př́ístupné z předpecní jámy. Nakládací otvor mohl být umístěn z boku nebo na protilehlé straně. Archeologicky nebylo doloženo, že vsádka byla umístěna výše nad palivem, nebo oddělena od paliva pomocí roštu (srov. Procházka 2015, 217). Vzhledem ke kratšímu tahu plamene je ovládání atmosféry v peci či teploty výpalu značně omezeno, takže velikost pece mohla být rozhodujícím faktorem pro kvalitu výpalu. Pyrotechnologické a etnoarcheologické výzkumy těchto pecí ukázaly, že ve vertikálních pecích o průměru 1 metru mohla teplota výpalu dosahovat 800 až $900{ }^{\circ} \mathrm{C}$, někdy dokonce i $1000{ }^{\circ} \mathrm{C}$ (srov. Vágner 2002, 314, 335; Kaltenberger 2009, 253).

Mezi klasické prŕíklady pecí tohoto typu patří pec ze Starého Mýta (k. ú. Tisová) nalezená v kontextu zaniklé městské lokace a publikovaná M. Richterem (1994). Jedná se o jednoprostorovou vertikální pec hruškovitého tvaru o rozměrech $1,6 \times 1,3$ metru s předpecní jámou umístěnou před ústím pece (obr. 7). Výška kupole dosahovala kolem 1 metru. Ve vypalovacím prostoru pece bylo nalezeno asi 50 až 60 nádob, které byly kladeny dnem vzhůru ve dvou řadách nad sebou. Objevuje se zde jak keramika starší domácí (hradištní) tradice, tak keramika kolonizační vrcholně středověká (světlá a červeně malovaná keramika). Na dnech keramických nádob se objevují značky (přibližně z 50\%), a to včetně identických značek. Pec je datována na základě

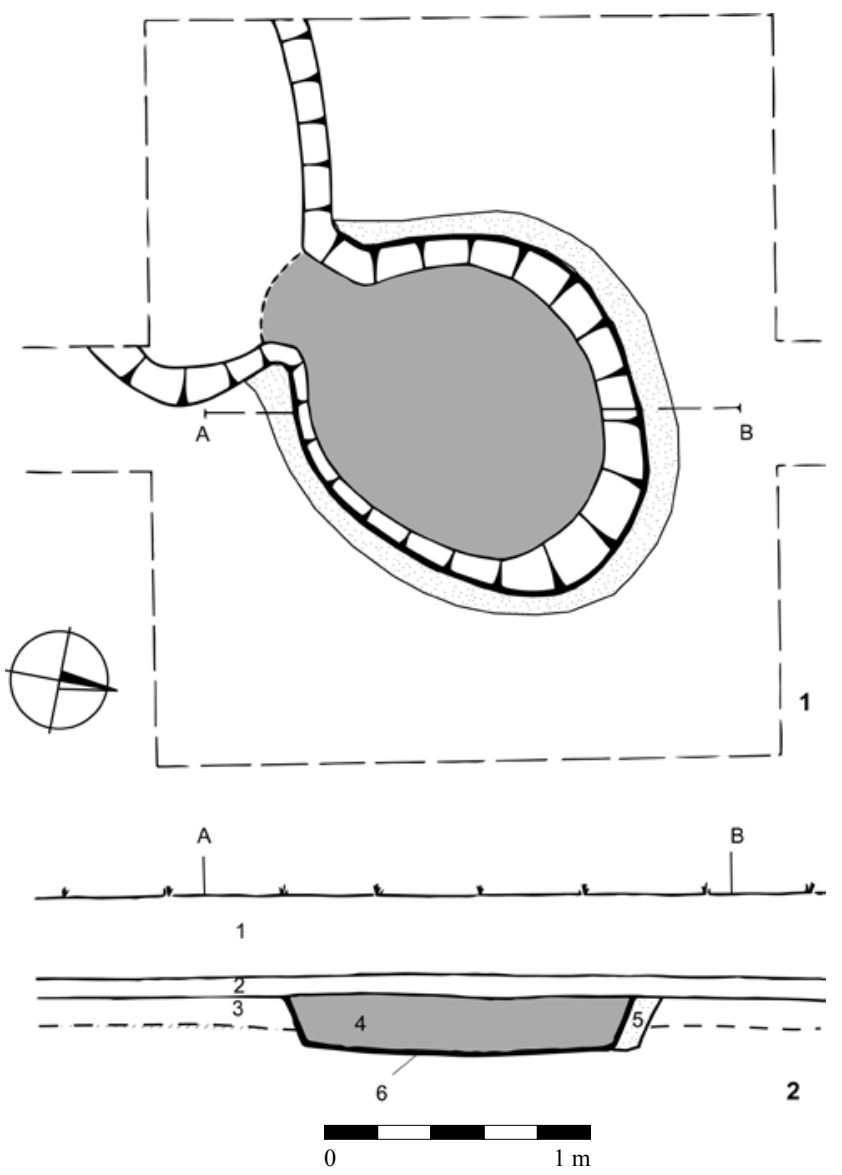

Obr. 7. Hrnčířská pec ze Starého Mýta (k. ú. Tisová). 1 - půdorys pece, 2 - řez pecí; popis uloženin: 1 - ornice, 2 - šedá hlína s mazanicí, 3 - šedá hlína, 4 - výplň pece, 5 - vypálené podloží, 6 - výmaz pece. Podle Richter 1994, obr. 2, upravil L. Čapek. Abb. 7. Töpferofen aus Staré Mýto (Katastergebiet Tisová). 1 - Ofengrundriss, 2 - Ofenprofil; Beschreibung der Ablagerungen: 1 - Ackerboden, 2 - Graulehm mit Lehmbewurf, 3 - Graulehm, 4 - Ofeneinsatz, 5 - verbrannter Untergrund, 6 - Ofenausschmierung. Nach Richter 1994, Abb. 2, bearbeitet von L. Čapek. 
keramiky z výplně pece do poloviny 13. století. Ze stejné lokality pochází ještě jeden nález konstrukčně podobné pece vzdálený zhruba 30 metrů, pec ale nebyla podrobněji zkoumána.

Mezi nejstarší př́iklady jednoprostorových vertikálních pecí patří nálezy dvou výrobních zařízení (č. 1 a č. 2) z Kostelce nad Orlicí, které byly odkryty při těžbě cihlářské hlíny v hliníku místní cihelny v letech 1956 a 1957 (výzkum M. Richtera). Pec č. 1 o rozměrech 1,8 $\times 1,3$ metru a pec č. 2 o rozměrech $1,2 \times 1$ metr byly nalezeny ve vzájemné superpozici. Starší pec č. $2 \mathrm{~s}$ nálezem keramické nádoby s hrnčířskou hlínou byla porušena výkopem pro mladší pec č. 1, jejíž ústí se mírně zužovalo (obr. 8). Kromě toho byla nalezena v blízkosti pecí odpadová jáma s množstvím zmetků. Pece jsou datovány do průběhu první poloviny 13. století (Richter 1967, 502).

Také v České Lípě, v okolí kostela sv. Máří Magdalény, byla nalezena jednoprostorová vertikální pec č. 2 kruhového půdorysu o průměru 1,5 metru. Její obvod vymezovala řada kůlových jamek, které pravděpodobně patřily ke dřevěné (proutěné) konstrukci stěn, a klenby omazané hlínou (obr. 9). Na základě nálezů keramiky ze dna, byla pec datována do druhé poloviny 13. století (Gabriel 1979, 257, 262, obr. 1; Gabriel 1981, 195-197; Gabriel-Panáček 2000, obr. 1).

Další nálezy jednoprostorových vertikálních pecí pocházejí z Malé Strany v Praze. Vesměs se jedná o menší pece kruhového až oválného tvaru datované do průběhu 13. století (Havrda-Matějková-Tryml 2012; Havrda-Matějková 2014, 42-44, obr. 17). Dvě pravděpodobně jednoprostorové vertikální pece (č. V a VI) byly objeveny při výzkumu na náměstí Republiky v Praze - Novém Městě, jsou datovány do pokročilého 15. století (Volf 2014, 25-26).

Mezi jednoprostorové vertikální pece patří pec z Tábora - Sídliště nad Lužnicí (někdejší Pražské předměstí) publikovaná R. Krajícem (1982, 269-276). Pec o rozměrech 1,8 $\times 2$ metry byla odkryta kompletně v celém půdoryse. Měla dochovanou hliněnou kupoli se dvěma otvory ve stěnách pece (obr. 10). Jeden zazděný otvor v čele pece sloužil jako nakládací pro vložení vsádky, druhý, boční je interpretován jako topeniště a byl rovněž uzavřen. Před topeništěm se

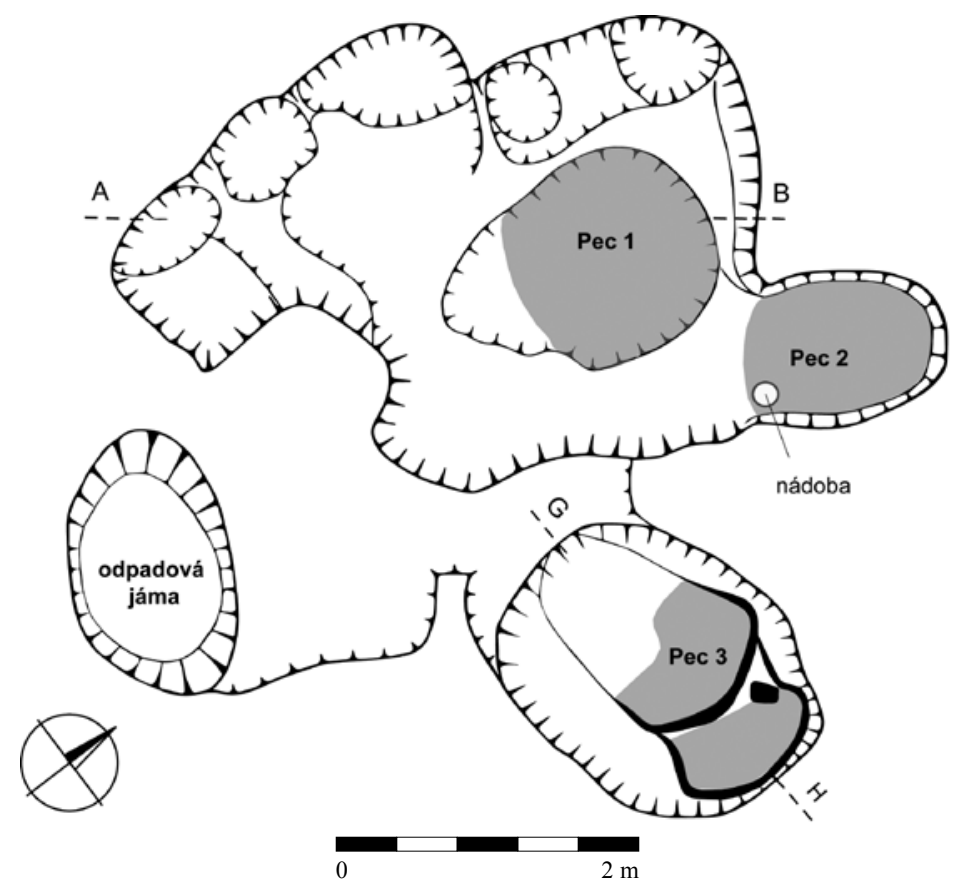

Obr. 8. Hrnčířské pece z Kostelce nad Orlicí - objekty pecí 1-3 vyznačeny. Podle Richter 1967, obr. 161, upravil L. Čapek. Abb. 8. Töpferöfen aus Kostelec nad Orlicí - Ofenobjekte 1-3 gekennzeichnet. Nach Richter 1967, Abb. 161, bearbeitet von L. Čapek. 


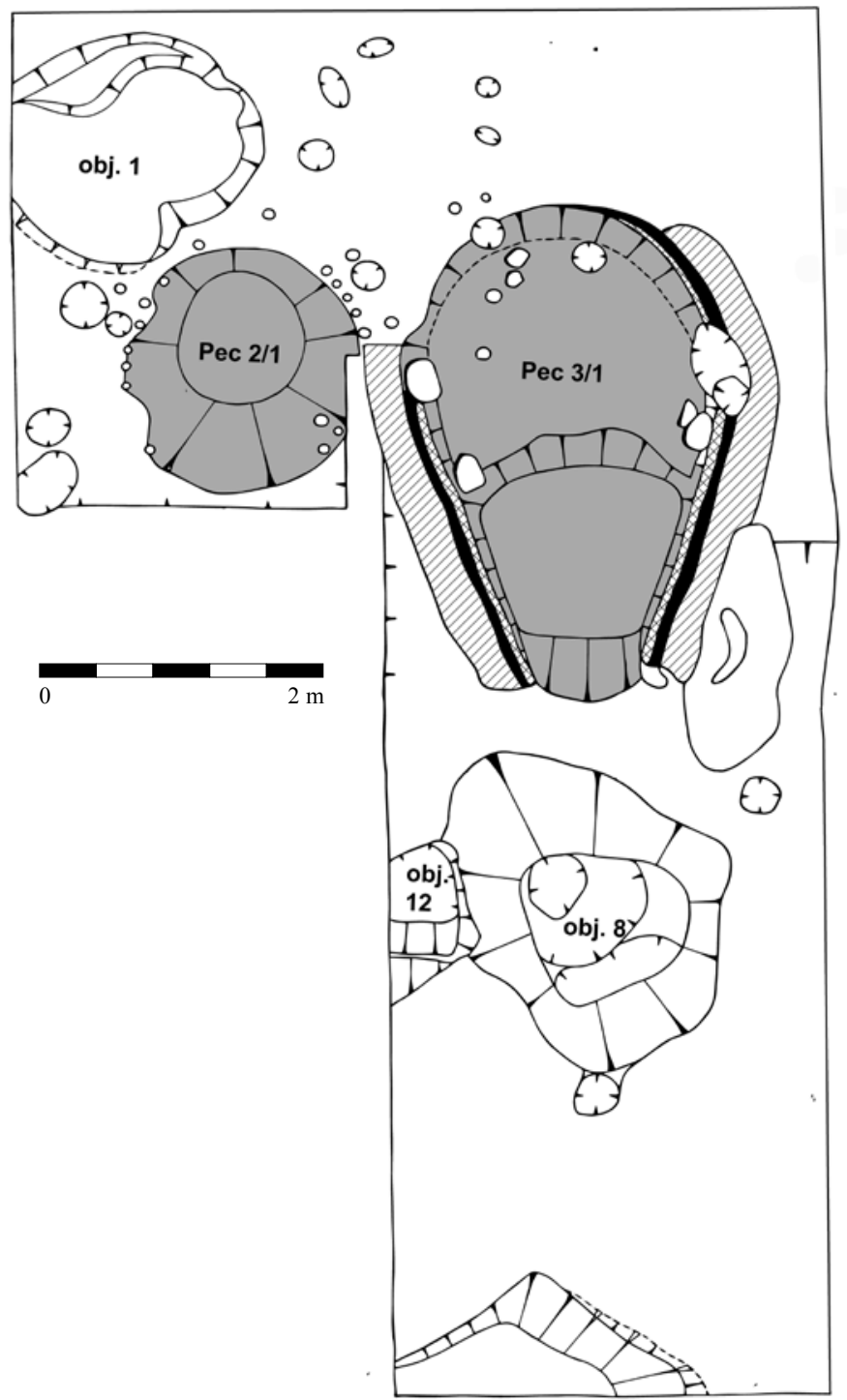

Obr. 9. Hrnčířská pec z České Lípy - pece č. 2/1 a 3/1 vyznačeny. Podle Gabriel 1979, obr. 1, upravil L. Čapek.

Abb. 9. Töpferofen aus Česká Lípa - Öfen Nr. 2/1 und 3/1 gekennzeichnet. Nach Gabriel 1979, Abb. 1, bearbeitet von L. Čapek.

nacházela lichoběžníkovitá předpecní jáma s množstvím keramiky. Pec je datována do druhé poloviny 14. století.

Jednoprostorové vertikální pece se používaly také v 15 . století a užívány byly i v raném novověku. Dokládají to nálezy několika pecí z Hořejšího předměstí v Domažlicích (autorem jsou nesprávně označované jako milírovité pece ${ }^{5}$ ), nebo dvě pece č. $4 \mathrm{a}$ a $4 \mathrm{~b}$ z usedlosti X v Sezimově

5 Milírovitá pec se od vertikální pece odlišuje tím, že je stavěna na povrch rovného, mírně upravovaného původního terénu a není do něj zahloubena. Navíc se jedná pouze o dočasnou konstrukci, která je po výpalu vsádky rozebrána (srov. Snášil 1970, 329; Thér 2004, 40). Již z toho důvodu nemůžeme pece z Domažlic zařadit mezi milírovité pece. Pece byly navíc prokazatelně zahloubeny do původního povrchu. 


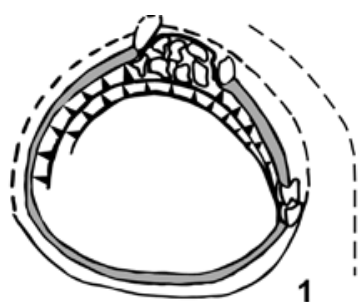

1

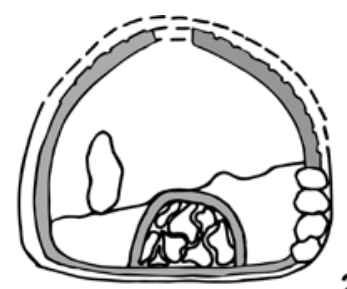

2

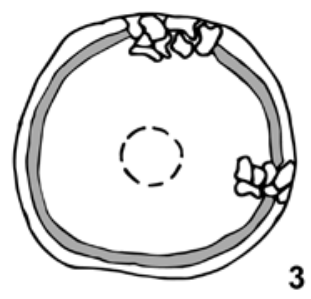

3

A

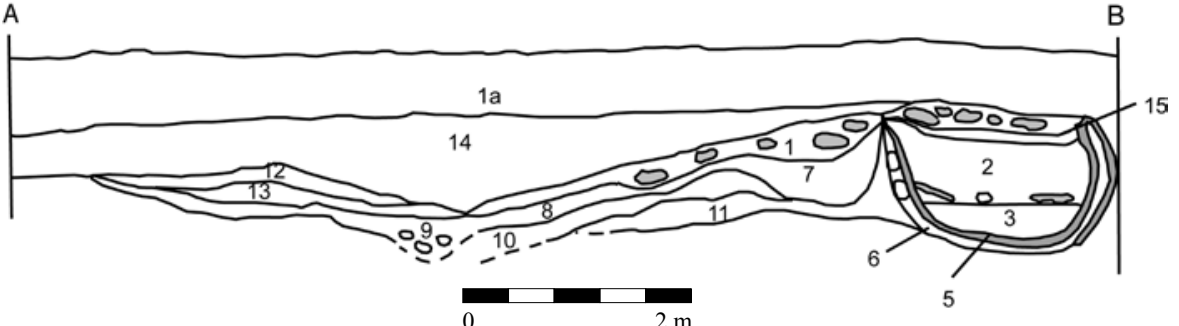

4

Obr. 10. Hrnčířská pec z Tábora - Sídliště nad Lužnicí. 1 - půdorys dna, 2 - boční pohled, 3 - pohled ze shora, 4 - řez pecí věetně předpecní jámy; popis uloženin: 1 - hnědočerná hlinitá s kameny - navážka, $1 \mathrm{a}$ - hnědá hlinitá s cihlovou drtí a kameny - navážka, 2 - hnědá hlinito-písčitá, 3 - černá propálená s mazanicí a cihlovinou, 5 - šedočerná mazanice z vnitřní vyzdívky klenby pece, 6 - cihlově červený vnější plášt' pece, 7 - šedočerná hlinitá v předpecní jámě, 8 - černá uhlíková, 9 - zahloubení do vrstvy 8, složením analogická, 10 - žlutá hlinitojílovitá s uhlíky, 11 - hnědá hlinitá, 12 - šedá jílovitá s kameny, 13 - šedohnědá jílovitohlinitá, 14 - hnědá hlinitá s cihlovinou, 15 - černošedá hlinitá. Podle Krajíc 1982, obr. 2 , upravil L. Čapek.

Abb. 10. Töpferofen aus Tábor - Siedlung an der Lainsitz. 1 - Bodengrundriss, 2 - Seitenansicht, 3 - Blick von oben, 4 - Ofenprofil einschließlich Vorofengrube; Beschreibung der Ablagerungen: 1 - grau-schwarz lehmhaltig mit Steinen Aufschüttung, 1a - braun lehmartig mit Ziegelsteinbruchstücken - Aufschüttung, 2 - braun lehmig-sandig, 3 - schwarz verbrannt mit Lehmbewurf und Ziegelmasse, 5 - grau-schwarzer Lehmbewurf von der Kuppelinnenausmauerung des Ofens, 6 - ziegelfarbig roter Außenmantel des Ofens, 7 - grau-schwarz lehmhaltig in der Vorofengrube, 8 - schwarz holzkohlehaltig, 9 - Eintiefung in Schicht 8, in der Zusammensetzung vergleichbar, 10 - gelb lehm-tonhaltig mit Holzkohle, 11 - braun lehmhaltig, 12 - grau tonhaltig mit Steinen, 13 - grau-braun ton-lehmhaltig, 14 - braun lehmhaltig mit Ziegelsteinmasse, 15 - rot-grau lehmhaltig. Nach Krajíc 1982, Abb. 2, bearbeitet von L. Čapek.

Ústí, datované ante quem (zánikový horizont) rokem 1420 (obr. 11). Dosud nepublikovaný je nález baterie hrnčiřrských pecí č. 6-7 ve vzájemné superpozici z výzkumu na nádvoří bývalého augustiniánského kláštera na náměstí Mikuláše z Husi čp. 44 v Táboře, které lze datovat do širokého časového intervalu od 15. do 17. století (Krajíc 2007, 155). V posledních letech byly objeveny dvě jednoprostorové vertikální pece při výzkumu v ulici Politických vězňů p. č. 296 v Berouně, datované předběžně na přelom 16. a 17. století (Benková 2014, 940-941, obr. 6-7).

U pecí z Domažlic, Sezimova Ústí, Tábora - Mikuláše z Husi čp. 44 a Berouna - ulice Politických vězňủ p. č. 296 by byl žádoucí detailnější rozbor nálezové situace včetně prezentace jejich půdorysné podoby a řezů (profilů) pecí. Všechny zmíněné pece doprovázely další významné doklady hrnčířské výroby, jako nálezy hliníků, deponií hrnčířské suroviny, sklípků na zrání jílů, střepišt', skladovacích objektů aj.

\subsection{Jednoprostorová horizontální pec s nečleněným vypalovacím prostorem (typ 2a)}

Velkou skupinu tvoří jednoprostorové horizontální pece, u nichž je prostor topeniště a peciště řazen za sebou $\mathrm{v}$ podélném směru. Tah plamene prostupoval rovnoměrně vnitřkem pece po celé délce. Teplota a atmosféra výpalu v peci mohla být lépe kontrolována, než tomu bylo u jednoprostorových vertikálních pecí. Horizontální pece rozdělujeme na skupiny s nečleněným vypalovacím prostorem a na skupiny, u nichž je topeniště a vypalovací prostor oddělen soklem 


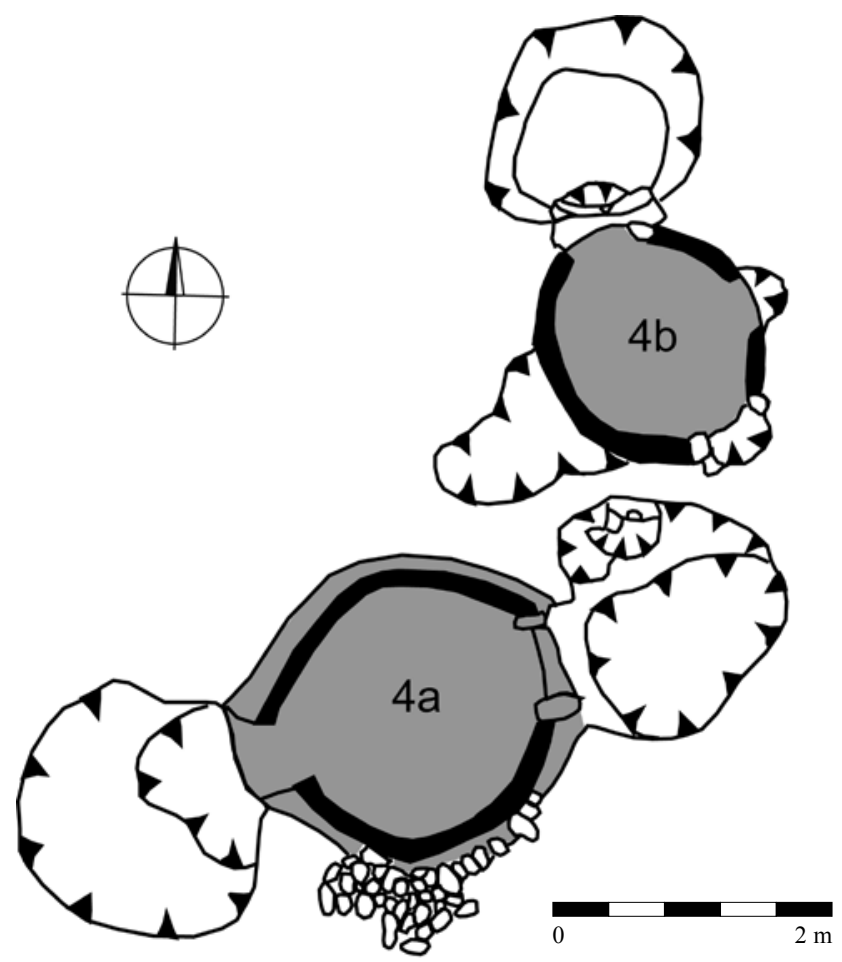

Obr. 11. Hrnčírské pece 4a a 4b z usedlosti X v Sezimově Ústí. Podle Richter-Krajíc 2001, upravil L. Čapek. Abb. 11. Töpferöfen 4a und $4 b$ aus Anwesen $X$ in Sezimovo Ústí. Nach Richter-Krajíc 2001, bearbeitet von L. Čapek.

či jinou formou dělicí přepážky (Vágner 2002, 314; Heege 2007, 7, 16-18; Kaltenberger 2009, 255; Procházka 2015, 217). Tento typ náleží pecím, u nichž takové rozdělení chybí a dno pece je rovné (topeniště a vypalovací prostor se nachází ve stejné výškové úrovni), nebo se mírně zvedá v šikmém směru. V půdoryse mají tyto pece mírně protáhlý oválný nebo hruškovitý tvar. Rozměry pecí tohoto typu se v Čechách nejčastěji pohybují kolem 2,6 × 1,6 metru. Pece měly rovněž hliněnou kupoli nebo kupoli sestavenou z keramických nádob (podrobně hodnoceno $\mathrm{v}$ samostatné kapitole 5.2.1). Výhodou dvouprostorových pecí, vůči jednoprostorovým, je snadnější kontrola průběhu výpalu a možnost dosažení lepší homogenity vypalovací vsádky. Navíc vsádka většinou není v př́mém kontaktu s palivem.

Mezi př́iklady tohoto typu patří nález hrnčířské pece z Bakova nad Jizerou, k němuž došlo při záchranném archeologickém výzkumu v letech 1963 a 1964. Objeveno bylo torzo pece obdélníkovitého až hruškovitého tvaru o rozměrech $3 \times 2,5$ metru (obr. 12). Na východní straně se nacházela mělká (předpecní?) jáma. Pec měla keramickou klenbu sestavenou z hrncovitých nádob. Na základě keramiky byla pec datována do pokročilého 15. století (Hrdlička 1967, 510-523).

Další půdorysně, ale i konstrukčně podobné zařízení představuje pec z Plzně. Byla nalezena v letech 1963 až 1965 při archeologickém výzkumu v Lochotínské ulici. Pec hruškovitého tvaru o rozměrech asi $3 \times 1,5$ metru měla základ postavený z kamenů a nedokonale vypálených cihel na pískovcovém podloží (obr. 13). Také tato pec měla kupoli sklenutou z keramických nádob (pohárovitých kachlů). Bohužel k této peci postrádáme řez/profil v celé délce, který by pec jednoznačně zařadil $\mathrm{k}$ tomuto typu. Pec je datována na základě rozboru keramické vsádky do první poloviny 15. století (Doubová-Nechvátal 1996, 62-66). 


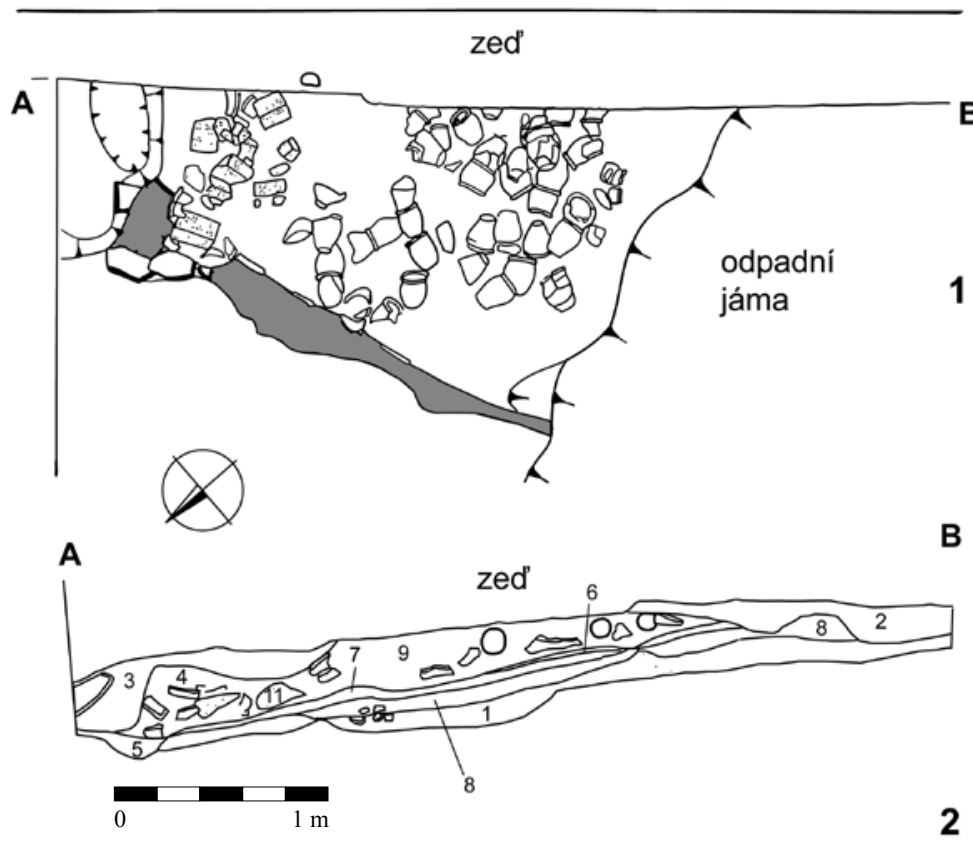

Obr. 12. Hrnčířská pec z Bakova nad Jizerou. 1 - půdorys pece včetně destrukce keramické klenby, 2 - řez pecí; popis uloženin: 1 - humus, 2 - hnědá humusovitá hlína, 3 - hlinitý písek s maltou a kameny, 4 - hnědá hlína s příměsí do červena vypálené hlíny, 5 - šedohnědá písčitá hlína, 6 - cementově šedá, žárem stmelená písčitá vrstva, 7 - okrově hnědá vypálená písčitá vrstva, 8 - cihlově červená vypálená hlína, 9 - hnědá hlína s př́íměsí do červena vypálená hlíny, 11 - jemný světlý písek. Podle Hrdlička 1967, obr. 166, upravil L. Čapek.

Abb. 12. Töpferofen aus Bakov nad Jizerou. 1 - Ofengrundriss einschließlich Zerstörungsschicht der Keramikkuppel, 2 - Ofenprofil; Beschreibung der Ablagerungen: 1 - Humus, 2 - brauner humushaltiger Lehm, 3 - lehmartiger Sand mit Mörtel und Steinen, 4 - brauner Lehm mit Beimischungen rotgebrannten Lehms, 5 - grau-brauner sandartiger Lehm, 6 - zementgrau, durch Glut verkittete sandige Schicht, 7 - ocker-braun gebrannte sandige Schicht, 8 - ziegelrot gebrannter Lehm, 9 - brauner Lehm mit Beimischungen rotgebrannten Lehms, 11 - feiner heller Sand. Nach Hrdlička 1967, Abb. 166, bearbeitet von $\mathbf{L}$. Čapek.

K jednoprostorovým horizontálním pecím lze zařadit i pec z Horšovského Týna, která byla zjištěna pouze v torzu na hraně výkopu v délce zhruba 2,5 metru. Základ pece byl zahlouben do žlutého jílovitého podloží a tvořily jej ploché kameny kladené na plocho. Na tento základ byla postavena konstrukce tělesa pece, kterou tvořily keramické nádoby postavené dnem vzhůru a silně omazané jílovitou hlínou (obr. 14). Bohužel pec byla zkoumána jenom z jedné třetiny a nálezová situace neumožňuje bližší rekonstrukci. Na základě rozboru keramických nádob nalezených v peci byla pec datována na přelom 15. a 16. století (Frýda 1992, 187-193).

Mezi jednoprostorové horizontální pece lze zařadit i pec č. 8 obdélného půdorysu z Malostranského náměstí čp. 258 v Praze - Malé Straně (Čiháková-Zavřel 1993, 199-200; HavrdaMatějková 2014, 43) a pece č. I (?), II a IV z výzkumu na náměstí Republiky v Praze - Novém Městě (Kašpar-Žegklitz 2009, 79-81; Volf 2014, 23-24). Snad jednoprostorová horizontální pec byla objevena v rámci výzkumu usedlosti XII v Sezimově Ústí (Richter-Krajíc 2001, 72).

Mezi jedny z nejmladších archeologicky doložených jednoprostorových horizontálních pecí patří pec z druhé poloviny 16. století objevená v Berouně, v České ulici čp. 56 (Vařeka 2004, 79), a taktéž trojice pecí cihlové konstrukce objevených při výzkumu v ulici Politických vězňủ p. č. 296, datovaných na přelom 16. a 17. století (Benková 2014, 940-941). V těchto pecích se pálila cihlově červená keramika s malbou na bílé nástřepí, označovaná jako berounské zboží (Matoušek-Scheufler 1983). 


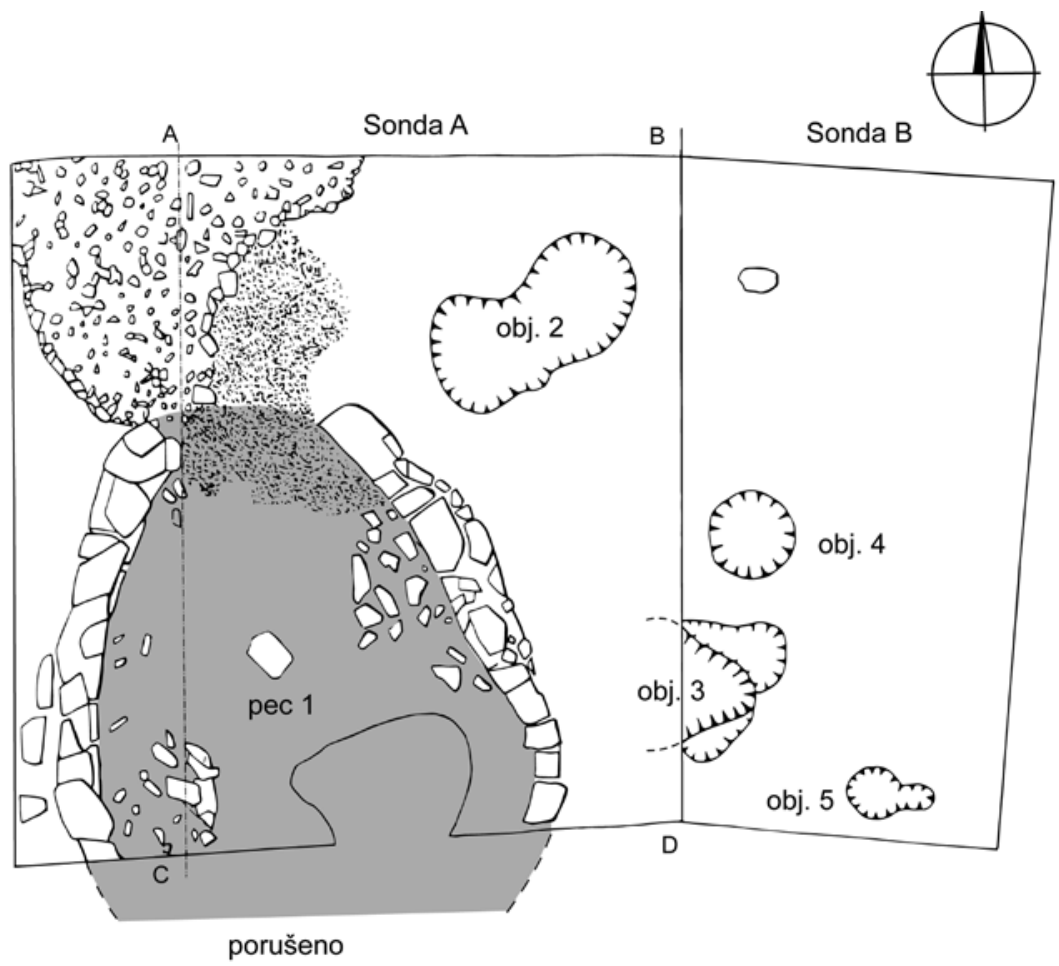

Obr. 13. Hrnčírská pec z Plzně - Lochotínské ulice. Podle Doubová-Nechvátal 1996, obr. 3, upravil L. Čapek. Abb. 13. Töpferofen aus Pilsen - Lochotínská-Str. Nach Doubová-Nechvátal 1996, Abb. 3, bearbeitet von L. Čapek.

\subsubsection{Jednoprostorové horizontálni pece s keramickou klenbou}

U jednoprostorových horizontálních pecí se nejčastěji setkáváme s konstrukcí klenby sestavenou z keramických nádob. Tyto pece s keramickou klenbou nevyčleňujeme jako samostatný typ, ale pouze jako určitou variantu, která se vyskytuje výhradně u těchto typů pecí. První pece s keramickou klenbou registroval již K. Čermák na počátku 20. století při výzkumech v Čáslavi (Čermák 1905, 567-572). Keramickou klenbu sestavenou z hrncovitých nádob naskládaných na sebe ve čtyřech souběžných řadách měla pec z Bakova nad Jizerou. Hrncovité nádoby válcovitého tvaru (ca $30 \mathrm{ks}$ ) se vyznačovaly neobvyklou uniformitou tvaru a lišily se od sebe pouze svými rozměry. V horní třetině výšky nádob byla prstem provrtána dvojice protilehlých otvorů, které sloužily ke vzájemnému přichycení (Hrdlička 1967, 511-515).

Také pec z Plzně - Lochotínské ulice měla kupoli sklenutou z nádob a pohárovitých kachlů s kruhovým ústím (celkem jich bylo nalezeno kolem $60 \mathrm{ks}$ ). Pohárovité kachle byly spojeny vypálenou hlínou (mazanicí). Při jejich rozboru bylo zjištěno, že ne všechny nádoby byly použity do konstrukce pece, a sami autoři zpochybňují vyslovenou domněnku o jejich užití v konstrukci klenby. V peci byl navíc zbytek vsádky obsahující keramiku různých typů (Doubová-Nechvátal 1996, 66).

Další pec s keramickou klenbou pochází ze Žatce. Objevena byla při výzkumu Chmelařského muzea (dnes součást jeho expozice). Dle popisu měla pec topeniště a peciště řazené za sebou. Lze ji tedy s výhradami zařadit mezi jednoprostorové horizontální pece. Klenba pece se skládala z nádob (hrnců s uchy) naskládaných do sloupců. Nádoby měly prořezané dno, zréejmě 
kvůli tomu, aby teplý vzduch ve sloupcích nádob mohl volně cirkulovat a pec rovnoměrně ohřívat. Pec je datována do druhé poloviny 14. století (Káčerik 2010, 453).

V Novém Strašecí byla odkryta konstrukce jednoprostorové, patrně horizontální pece s keramickou klenbou. Destrukce klenby o tloušt'ce $20 \mathrm{~cm}$ nesla otisky větších bezuchých hrnců spojovaných propálenou mazanicí. Pec je datována do první poloviny 15. století (Volfová-Volf 1999, 53-54).

Mezi dosud nepublikované nálezy hrnčířských pecí s keramickou klenbou patří objekt pece z Mostu - sídliště u kostela sv. Václava, České Lípy (pec č. 3) a patrně i ze zaniklé vsi pod Ronovem (Gabriel-Smetana 1982, 511-512). Nedávno byla objevena pec s keramickou klenbou v Hořicích. ${ }^{6}$

Mezi pece s keramickou klenbou je řazena také pec z Horšovského Týna. Podle popisu konstrukce byla kupole klenby tvořena dvěma řadami nádob postavených na sebe dnem vzhůru, čímž vznikl mírný oblouk. Jednotlivé nádoby byly spojeny mohutnou vrstvou vypálené mazanice (obr. 14).

Na stavbu klenby nebyla použita technická keramika, ale běžná tenkostěnná užitková keramika velkých rozměrů vykazující na první pohled jednotný charakter. Podíváme-li se však pozorněji, zjistíme, že se přece jen zmiňované nádoby tvarově, ale i rozměrově odlišují a uniformita je jenom zdánlivá. Autor výzkumu do předpokládané konstrukce klenby vedle hrnců zařadil i nález džbánu. Navíc jsou nádoby zdobené radélkovou výzdobou! Ve výplni či v okolí pece jsou doloženy zlomky dalších tvarů užitkové keramiky. Zaznamenány byly také nálezy zlomků komorových kachlů (Frýda 1992, 188-192, Tab. I a II). Pokud se ohlédneme k dalším nálezům pecí s keramickou klenbou (Bakov nad Jizerou, Žatec), bylo k jejich konstrukci užito spíše silnostěnné užitkové či technické keramiky často se zdrsněným povrchem a doloženými funkčními otvory v horní třetině výšky či ve dnech nádob. Zajištovaly proudění vzduchu a vyrovnávání teploty a tlaku v klenebních pásech (Meringer 1912, 152). Z těchto důvodů se nabízí možnost reinterpretace nalezených nádob v peci v Horšovském Týně jako pozůstatku nevyzvednuté keramické vsádky (!). Dalším argumentem je i to, že nádoby nebyly zasazeny do sebe, ale položeny v řadách nad sebou (srov. Frýda 1992, 193, Tab. V), tedy způsobem, jakým se nakládá keramická vsádka do pece. ${ }^{8}$ Zmiňovaný oblouk, který tvořily na sobě postavené nádoby, mohl vzniknout při sesutí vsádky po destrukci klenby. Nutné je ovšem připustit, že pec byla odkryta jenom zčásti, přibližně z jedné třetiny, což neumožňuje vyslovit zcela jednoznačné závěry o přesné konstrukční podobě klenby pece.

Pece $\mathrm{s}$ keramickou klenbou sestavenou $\mathrm{z}$ do sebe zasazených nádob jsou doloženy jak v západní, tak i východní Evropě. Známé jsou nálezy pecí ze Starého Města ve Winterthuru (Švýcarsko), datované do konce 14. a počátku 15. století (Lehmann 1992), nebo z Bamberku (Horní Franky), okolo roku 1500 (Löw-Karf 1993, 146). Konstrukce kleneb pecí sestavených z keramických nádob jsou dokonce etnograficky doloženy ještě na konci 19. a počátku 20. století na Slovensku, v Polsku, Mad’arsku a Ukrajině (Kalesný 1993, obr. 3a), nebo také v rakouském Burgenlandu (Kaltenberger 2009, 258-259).

\subsection{Jednoprostorová horizontální pec s dělicí přepážkou (typ 2b)}

Zvláštní konstrukční typ představují pece, u nichž je prostor topeniště a peciště rozdělen prŕíným vertikálním hliněným valem či tzv. dělicí přepážkou (srov. Heege 2007, 4, 8). Smyslem přepážky mezi topným a vypalovacím prostorem bylo zabránit mechanickému poškození

6 Viz http://www.kr-kralovehradecky.cz/cz/kraj-volene-organy/tiskove-centrum/aktuality1/unikatni-nalez-stredoveke-pece-v-horicich-72706/, cit. 21. 8. 2017. Podle sdělení kolegů z Katedry archeologie UHK je pec předmětem podrobného zpracování.

7 Keramické klenby byly vyráběny specializovanými hrnčíri. V Levíně bylo doloženo centrum hrnčířské výroby a také výroba stavební keramiky včetně tzv. klenáků, jež se použivaly pro stavbu klenebních pásů pecí sestavených z nádob. Zde vyráběné nádoby se vyznačovaly značnou uniformitou tvarů, ale také hrubším povrchem, který umožňoval lepší soudržnost jílovitého pojiva, jímž se vymazávaly spáry mezi klenbami (Votoček 1955, 214).

8 Skládání nádob do pecí se podřizovalo snaze o maximální využití vypalovacího prostoru. Jednotlivé nádoby se vkládaly na sebe i do sebe a byly stavěny dnem vzhůru (Zatloukal 2000,60). 

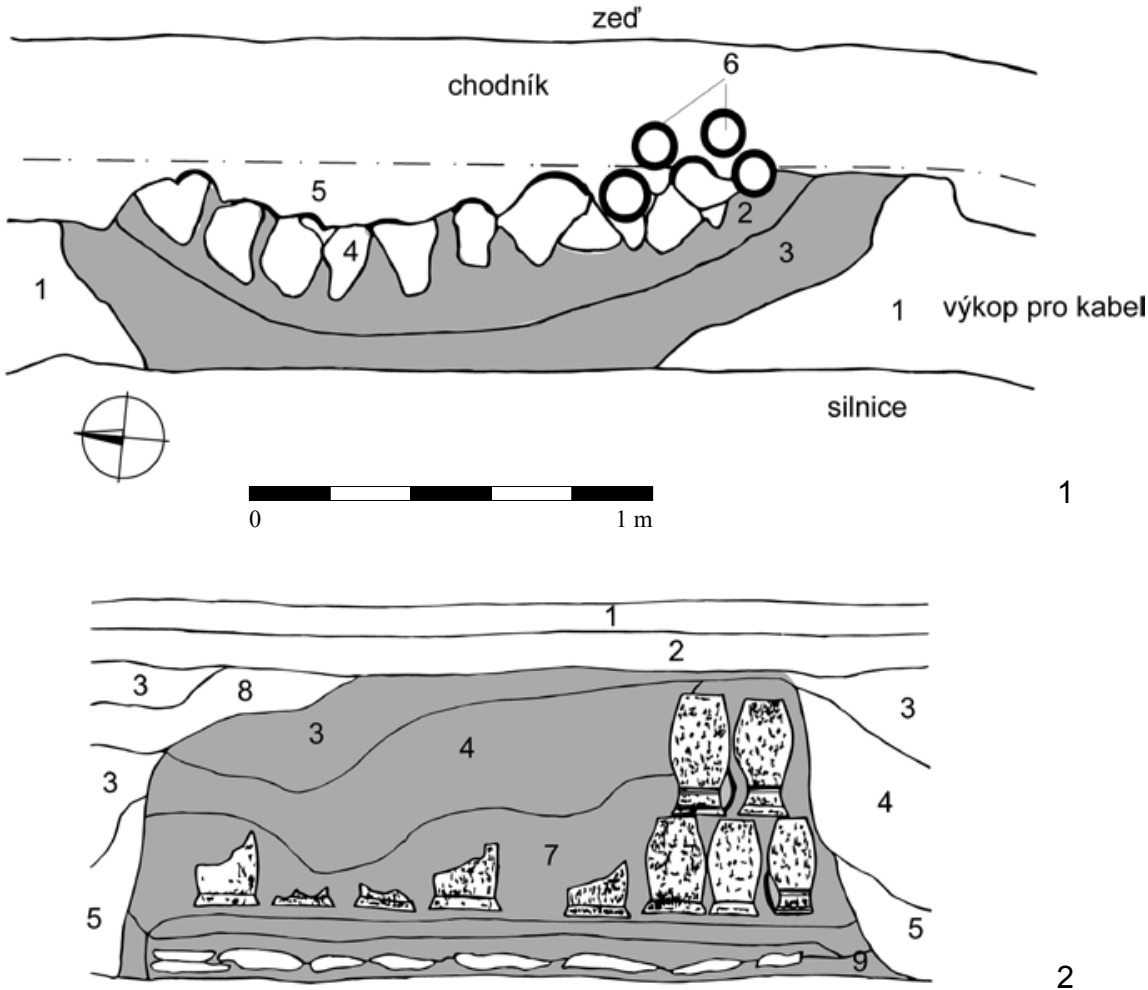

Obr. 14. Hrnčířská pec z Horšovského Týna. 1 - půdorys pece na hraně výkopu, 2 - řez stěnami pece včetně umístění keramických nádob; popis uloženin: 1 - chodník z dlaždic, 2 - vyrovnávací štěrkopísková navážka, 3 - destrukční vrstva pece, 4 - mazanice se zlomky nádob, 5 - žlutka, uhlíky, zlomky keramiky, 6 - jílovité podloží, 7 - keramika uložená v mazanici, 8 - hlinito-písčitá vrstva s obsahem zlomkové keramiky, 9 - přepálená žlutka s kameny základu pece. Podle Frýda 1992, Tab. IV a V, upravil L. Čapek.

Abb. 14. Töpferofen aus Horšovský Týn. 1 - Ofengrundriss am Grabenrand, 2 - Schnitt durch die Ofenwände einschließlich Verteilung der Keramikgefäße; Beschreibung der Ablagerungen: 1 - Verbundsteingehsteig, 2 - nivellierende Kiessand-Aufschüttung, 3 - Zerstörungsschicht des Ofens, 4 - Lehmbewurf mit Gefäßbruchstücken, 5 - Lössboden, Holzkohle, Keramikbruchstücke, 6 - toniger Untergrund, 7 - im Lehmbewurf enthaltene Keramik, 8 - lehm-sandige Schicht mit Keramikbruchstücken, 9 - verbrannter Lössboden mit Ofenfundamentsteinen. Nach Frýda 1992, Taf. IV und V, bearbeitet von L. Čapek.

prvních svislých řad vsádky nádob a ochránit je před prudkým vzestupem teplot v prvotní fázi výpalu (Volf 2014, 20).

Jediný prŕíklad svého druhu představuje pec č. 3 z Kostelce nad Orlicí, která doplňuje dvojici jednoprostorových vertikálních pecí (obr. 8). Pec se vymyká nejen svými malými rozměry $1,4 \times 1,1$ metru, ale především tím, že uprostřed se nacházejí stopy hliněného valu. Destrukce této přepážky, oddělující topný a vypalovací prostor, je patrná na archivních fotografích $\mathrm{z}$ výzkumu (obr. 15). Přístup k peci umožnila podlouhlá jáma svažující se povlovně k východu (Richter 1967, 503).

Při výzkumu vyvstala otázka, zda se nejedná o dvě jednodílné pece vložené do sebe, kde starší pec je porušena mladší pecí s přepážkou. Očazení přepážky z obou stran jednoznačně dokládá, že se jedná o jednu solitérní pec, kterou můžeme označit za jednoprostorovou horizontální pec (Richter 1967, 506, pozn. 6; srov. Varadzin 2010, 66). Pec byla datována do počátku 

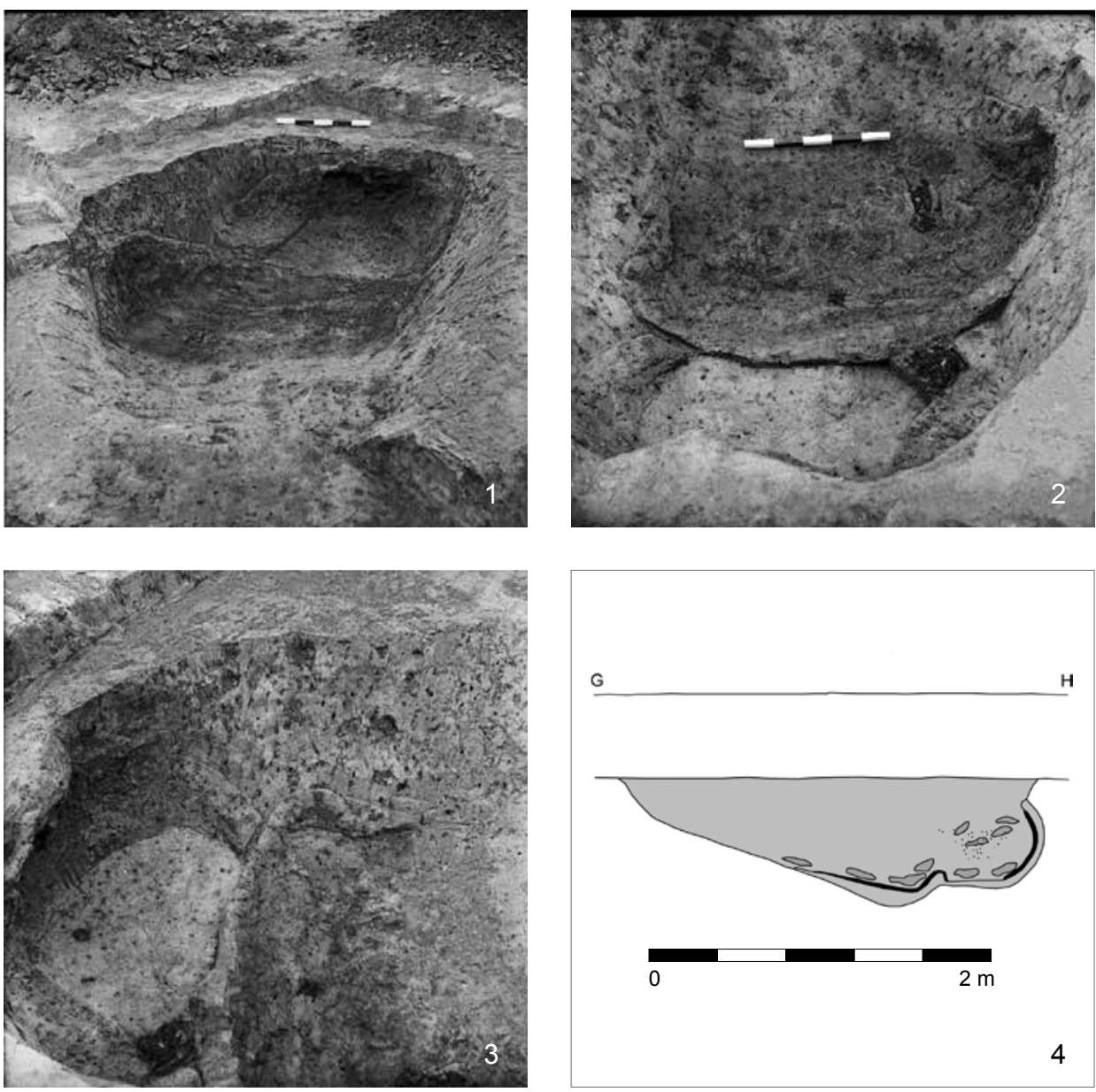

Obr. 15. Hrnčířská pec č. 3 z Kostelce nad Orlicí. 1-3 - detaily dělicí přepážky, 4 - řez pecí. Foto digitální archiv AV ČR v Praze, řez podle Richter 1967, obr. 162, upravil L. Čapek.

Abb. 15. Töpferofen Nr. 3 aus Kostelec nad Orlicí. 1-3 - Details der Trennwand, 4 - Ofenprofil. Foto digitales Archiv der Tschechische Akademie der Wissenschaften in Prag, Profil nach Richter 1967, Abb. 162, bearbeitet von L. Čapek.

13. století. Představuje tak nejstarší nález jednoprostorové horizontální pece v Čechách, a to se vzácně doloženým dělením topeniště a vypalovacího prostoru pomocí hliněné přepážky.

U žádné z dalších hrnčířských pecí v Čechách nebyl pozorován náznak obdobného příčného valu či přepážky, nejbližší analogie můžeme vysledovat v Německu, na lokalitě Sonderhausen/Stockhausen (Stoll 1961, 307), a v Polsku (Gajewski 1959, 344, ryc. 4). U vyspělejších konstrukčních variant pecí funkci přepážky nahradily hliněné sloupy, v německé literatuře označované jako Tonsäule (Heege 2007, 4).

\subsection{Jednoprostorová diagonální pec se členěným dnem pomocí soklu (typ 2c)}

Mezi jednoprostorové horizontální pece s diagonálním tahem plamene řadíme pece, u nichž se podlaha topného prostoru nacházela níže než podlaha vypalovacího prostoru nebo je topeniště od peciště odděleno soklem či stupněm. Toto členění dna umožňuje šikmé vedení 

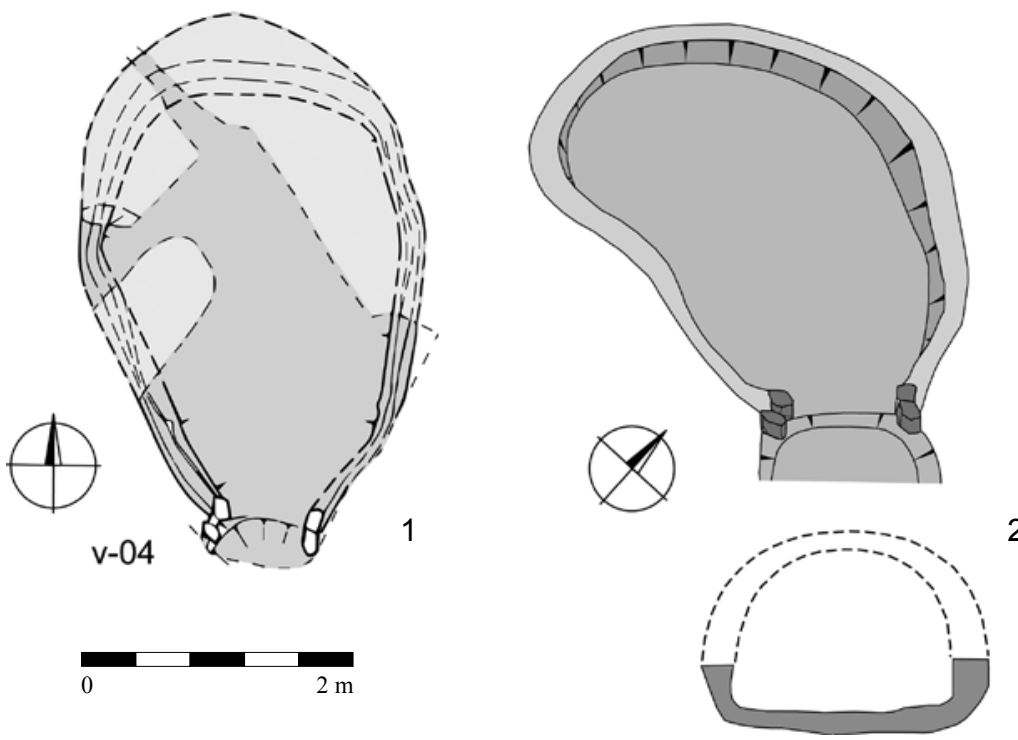

Obr. 16. Hrnčířská pec (v-04) z Vlašské ulice na Malé Straně v Praze. 1 - půdorys pece, 2 - axonometrický model pece a řez. Podle Havrda-Matějková 2014, obr. 4, a Praha archeologická, upravil L. Čapek.

Abb. 16. Töpferofen (v-04) aus der Vlašská-Str. auf der Kleinseite in Prag. 1 - Ofengrundriss, 2 - axonometrisches Ofenmodell und Profil. Nach Havrda-Matějková 2014, Abb. 4, a Praha archeologická, bearbeitet von L. Čapek.

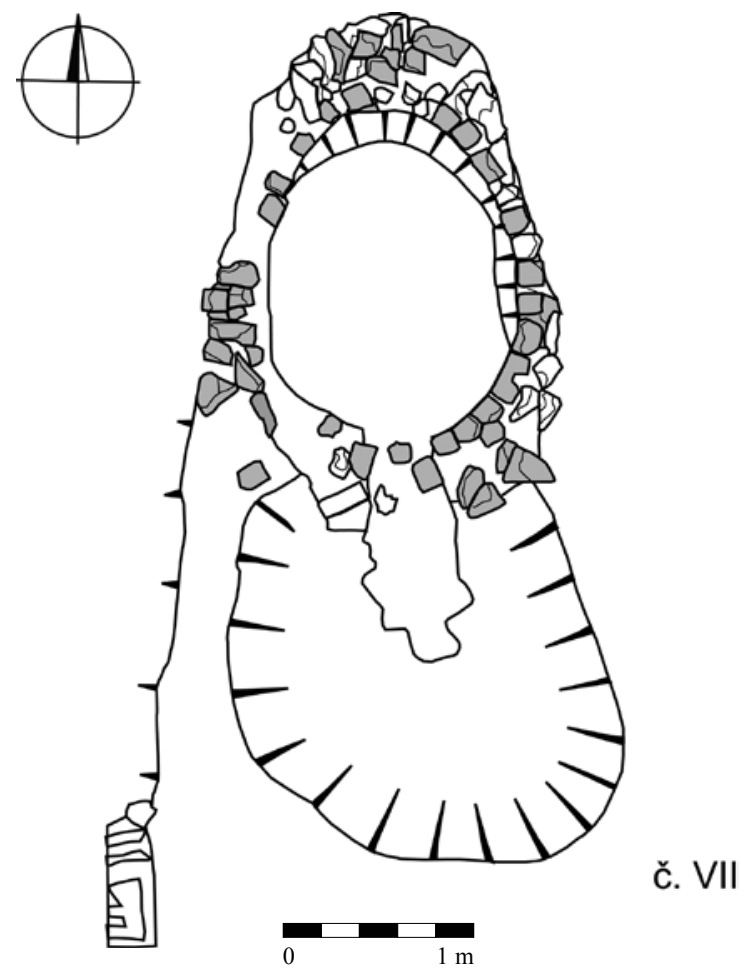

Obr. 17. Hrnčířská pec č. VII z náměstí Republiky v Praze - Novém Městě. Podle Volf 2014, upravil L. Čapek. Abb. 17. Töpferofen Nr. VII vom Platz der Republik in Prag - Neustadt. Nach Volf 2014, bearbeitet von L. Čapek. 
plamene, které prostupuje vnitřkem pece a stoupá vzhůru směrem k otvoru pro odvod kouře. Tyto pece bývají navíc často zahloubeny ve svažitém terénu (Heege 2007, 15-18).

Mezi nejstarší prŕíklady pecí tohoto typu lze zařadit, byt's určitými výhradami osm pecí (č. 1, 3-5, 7-8, 10 a 14) z České Lípy, které se vyznačovaly hruškovitým půdorysem. Blíže je archeologicky popsáno pouze několik pecí, které se lišily svými rozměry. Největší délky dosahovaly pece č. $3(3,5 \mathrm{~m})$ a č. $5(3,8 \mathrm{~m})$, největší šířku měla pec č. $4(2,6 \mathrm{~m})$. U ostatních pecí se šířka pohybovala kolem dvou metrů. $V$ př́padě pecí č. 1, 3, 5 a 7 bylo topeniště prokazatelně umístěno níže vzhledem k vypalovací komoře. Kupole byla pravděpodobně sklenuta $\mathrm{z}$ hrncovitých nádob. Před ústím pecí se nacházely předpecní jámy. Nejlépe a v úplnosti byla prozkoumána pec č. 3 o rozměrech 3,5 × 2 metry, jejíž dno bylo členěno soklem na více zahloubenou část při topném prostoru a část vyvýšenou, kde byla umístěna vsádka (obr. 9). Před ústím pece se nacházela předpecní jáma. Tato pec porušila v superpozici starší vertikální pec č. 2. Je tudíž vzácným př́íkladem vztahu dvou typově rozdílných pecí a potvrzením teorie, že horizontální pece jsou o něco mladší než pece vertikální. Všechny pece jsou datovány od druhé poloviny 13. století, spíše však až od počátku 14. století, na základě nálezů červeně malované keramiky z podlah pecí. Bohužel všechny hrnčířské pece v České Lípě, ${ }^{9}$ publikované pouze předběžně, nebyly dosud podrobněji vyhodnoceny. Jejich datování se pohybuje v intervalu od druhé poloviny 13. do počátku 14. století, některé však mohou být i mladší (Gabriel 1979, 257-264, obr. 1; 1981, 195-197; GabrielSmetana 1983, 120; Gabriel-Panáček 2000, 9-15, obr. 2-6).

Podobný půdorys jako pec č. 3 z České Lípy má i nedávno publikovaná pec z Vlašské ulice čp. 355 v Praze - Malé Straně (v-04), která se vyznačuje obdobným hruškovitým tvarem o rozměrech asi 3,7-3,5 × 2,6 metru, u které se úroveň podlahy směrem od ústí zvyšovala (obr. 16). Pec byla navíc zapuštěna do svažitého terénu. Základová konstrukce byla tvořena $\mathrm{z}$ cihel, stěny a kupole z mazanice. Pec byla datována před polovinu 14. století (Havrda-Matějková 2014, 26-27, obr. 4). Zdejší dílna vyráběla červeně malovanou keramiku a může být dokladem transferu této technologie z některé z oblastí severních či severozápadních Čech do pražského prostředí či prrímo dokladem existence hrnčíře pocházejícího z těchto oblastí, který se usadil v Praze.

Mezi pece s diagonálním vedením plamene náleží i nejlépe dochovaná pec č. VII z výzkumu na náměstí Republiky v Praze - Novém Městě. Pec o rozměrech 1,7 × 1,3 metru byla postavena ze smíšeného cihlového a kamenného zdiva (obr. 17). Na dně byly zjištěny doklady tř́ kanálů (tahů) tvořených opakovaně používanými nádobami a kachli. V zásypu pece bylo objeveno velké množství střešních prejzů (uvažuje se o jejich zapojení do konstrukce klenby, také práh topného prostoru byl tvořen obloukovitou krytinou). Pec pracovala od poslední třetiny 14 . až do poloviny 15. století (Kašpar-Žegklitz 2009, 80; Volf 2014, 26-28).

Mezi významná hrnčířská centra pozdně středověké a raně novověké keramické výroby patřilo královské město Beroun, kde byla v posledních letech objevena řada hrnčířských pecí produkujících jak pozdně středověkou redukční keramiku, tak i raně novověkou keramiku (tzv. berounské zboží), kterou dnes řadíme ke skupině renesanční vícebarevně malované keramiky, označované jako slipware nebo malhornware a rozšířené i v rámci jiných center v Evropě (Žegklitz 2015; Preusz 2017, 160-162).

Nejzachovalejší z berounských pecí, objevená v místech někdejšího Hrnčířského předměstí, je oválná jednoprostorová horizontální pec (č. s. j. 8-034) o rozměrech 3,9 × 1,9 metru s dnem mírně klesajícím $\mathrm{k}$ severu, kterou řadíme rovněž $\mathrm{k}$ pecím $\mathrm{s}$ diagonálním tahem plamene (obr. 18). Konstrukce stěn je tvořená $\mathrm{z}$ cihel a říčních valounů. $V$ peci byla nalezena vsádka redukčně pálené keramiky z druhé poloviny 15. století a nedaleko se nacházelo střepiště. V okolí byly doloženy hrudky žlutých hrnčířských jílů těžených v zázemí města (Vyšohlíd 2015, 163-168, obr. 6-7; 2015a, 418-419, obr. 11).

9 Mezi hrnčířské pece je v České Lípě řazeno až 15 objektů, vzhledem k jejich fragmentárnosti a stavu terénní dokumentace můžeme o funkci hrnčířských pecí uvažovat spolehlivě pouze max. v devíti př́ípadech (srov. Gabriel-Panáček 2000, 8-15, obr. 1-6). 

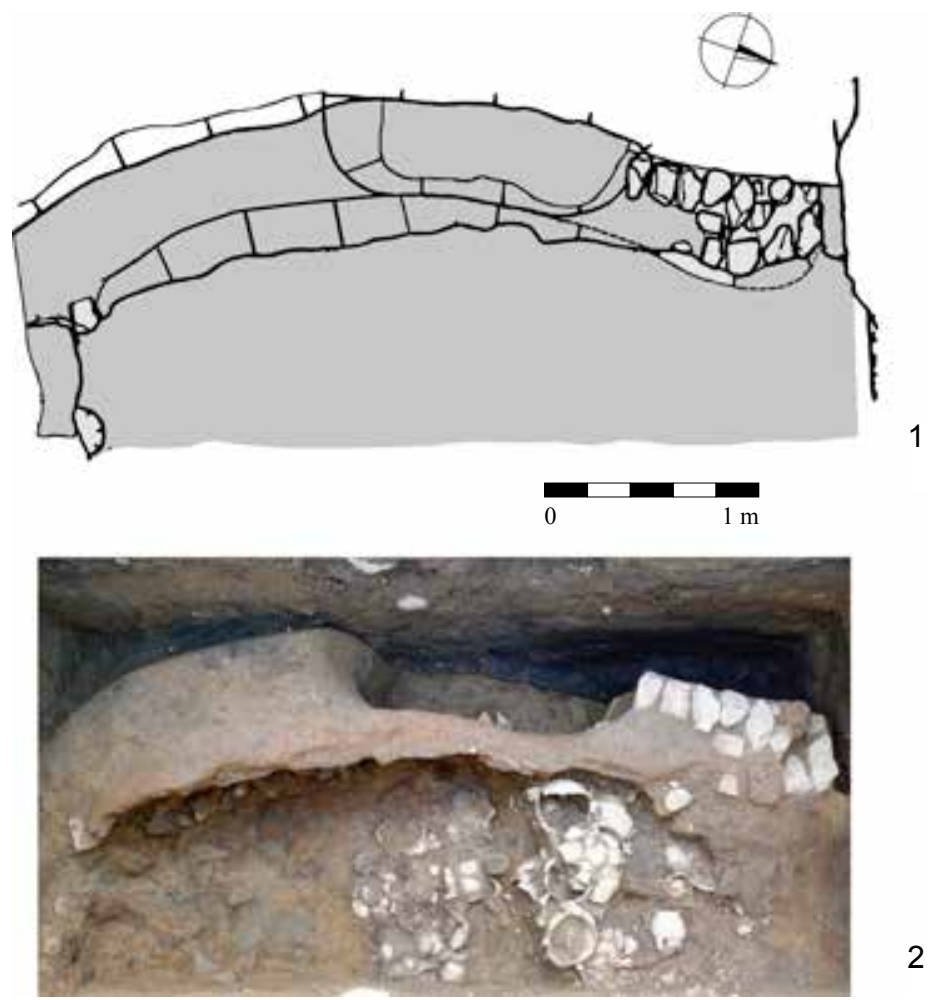

Obr. 18. Hrnčířská pec (s. j. 8-034) z Berouna - Hořejšího předměstí. 1 - půdorys, 2 - fotografie pece včetně keramické klenby. Podle Vyšohlíd 2015a, obr. 6 a 7, upravil L. Čapek.

Abb. 18. Töpferofen (strat. Einheit 8-034) aus Beroun - Obere Vorstadt. 1 - Grundriss, 2 - Foto des Ofens einschließlich Keramikkuppel. Nach Vyšohlíd 2015a, Abb. 6 und 7, bearbeitet von L. Čapek.

\subsection{Jednoprostorová horizontální pec s dělicími sloupky/pilířky (typ 2d)}

Vrat'me se ještě k nálezům pecí z náměstí Republiky v Praze - Novém Městě. Pozoruhodná je jednoprostorová horizontální pec č. II, za jejímž ústím byly objeveny na dně dva cihlové pilířky, od nichž se rozbíhaly další cihly sestavené do půdorysu $\mathrm{V}$, které dělily prostor při podlaze do tř́i tahů (obr. 19 a 20; Kašpar-Žegklitz 2009, 80-81; Volf 2014, 24). Funkce pilířků spočívala v rozvádění tepla $\mathrm{z}$ topeniště $\mathrm{v}$ přední části do vnitřního prostoru, o čemž svědčí i jejich očazení. Pec obsahovala velké množství užitkové keramiky, včetně zmetků. Pec je datována ante quem před polovinu 15. století. Funkce těchto dělicích pilíř̉u či sloupků je zmiňována v etnografické literatuře, kde jsou označovány jako tzv. štendry (Pajer 2007, 232).

$\mathrm{K}$ tomuto typu pecí by bylo možné s výhradami zařadit pec $\mathrm{z}$ Bakova nad Jizerou. Během výzkumu byla při ústí vypalovacího prostoru zjištěna dvojice hliněných kvádrů, které byly autorem výzkumu L. Hrdličkou interpretovány jako ostění otvoru topeniště (obr. 21; Hrdlička 1967, 511,518 , obr. 168). Na základě srovnání s nálezy z německého prostředí jsme dospěli k závěru, že funkce hliněných kvádrů mohla spočívat $v$ rozvádění tepla do více tahů ve vnitřním prostoru pece, podobně jako u pece č. II z náměstí Republiky v Praze - Novém Městě. Je jen škoda, že se těmto hliněným kvádrům, jež nesou stopy po výpalu, nevěnovala větší pozornost při výzkumu.

Také při výzkumu pecí v České Lípě bylo zaznamenáno před čelušní pece ve vrstvě několik měkce vypálených cihel se zakulacenými hranami. Bohužel stav dokumentace neumožňuje 

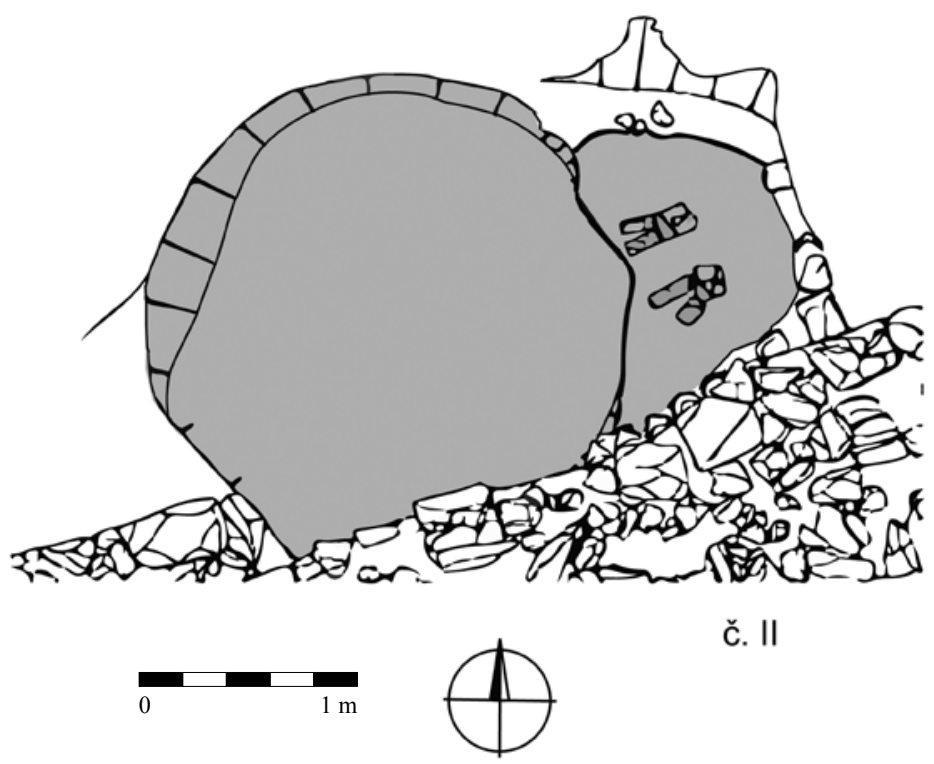

č. II

Obr. 19. Hrnčířská pec č. II z náměstí Republiky v Praze - Novém Městě. Podle Volf 2014, upravil L. Čapek. Abb. 19. Töpferofen Nr. II vom Platz der Republik in Prag - Neustadt. Nach Volf 2014, bearbeitet von L. Čapek.

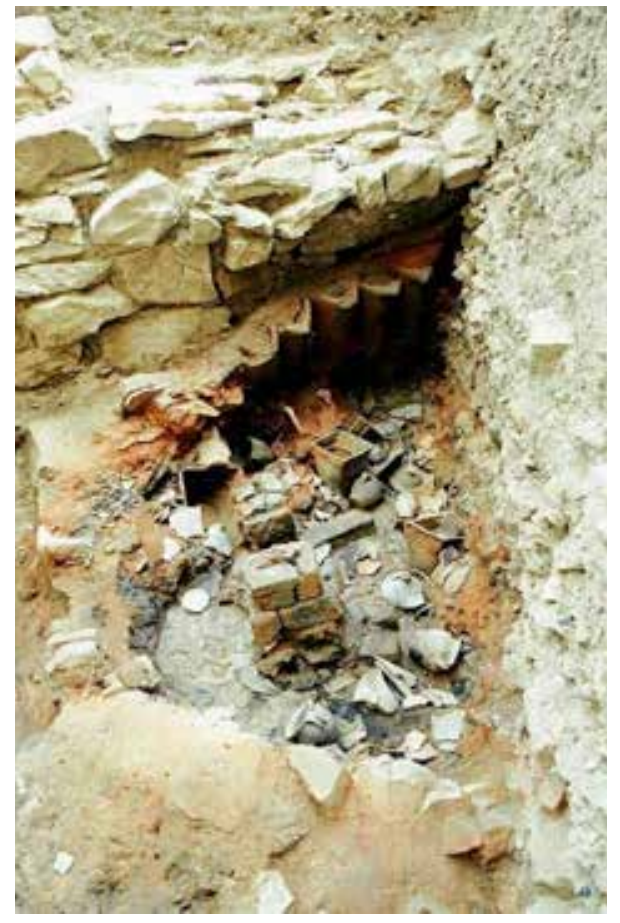

Obr. 20. Cihlové pilířky na dně pece č. II z náměstí Republiky v Praze - Novém Městě. Foto Archaia Praha, o.p.s.

Abb. 20. Ziegelsteinsäulen am Boden des Ofens Nr. II vom Platz der Republik in Prag - Neustadt. Foto Archaia Praha, o.p.s. bližší posouzení. Podobně je tomu i u dalších nálezů pecí č. 4,7 a 14 , kde podlahu topeniště, situovaného níže než vypalovací prostor, oddělují na horní hraně převýšení dvojice výstupů z čedičových kamenů omazaných vypáleným jílem. Autorem výzkumu byly interpretovány jako ,základ stěny chránici vysušené nádoby před př́mým nárazem plamene, třemi prostupujicimi otvory však dovolujici prüchod vysokých teplot $k$ vypalované keramice“ (Gabriel-Panáček 2000, 10-11, obr. 4).

Hypoteticky bychom mohli tyto pece také zařadit ke dvouprostorovým pecím. Vzhledem k torzovitosti nálezové situace a absenci pevné dělicí přepážky však tyto výrobní objekty řadíme mezi jednoprostorové pece.

\subsection{Jednoprostorová horizontální pec se stře- dovým soklem (?) (typ 2b)}

V Čechách se, na rozdíl od Moravy, neobjevují pece se středovým soklem/jazykem rozdělujícím vypalovací prostor do dvou kanálů, přičemž hliněný sokl mohl nést konstrukci mobilního roštu. Jediný sporný příklad představuje Vícov u Přeštic, kde byl objeven v rámci výzkumu vesnického sídliště u pozdně románského kostela sv. Ambrože 
půdorys mírně zahloubeného objektu č. 24/02 podkovovitého tvaru o rozměrech $1,2 \times 0,9$ metru se středovým hliněným soklem. Před objektem se nacházela podlouhlá předpecní jáma (?) č. 22/02 orientovaná př́íčně k ústí objektu (obr. 22; Pícka-Tetour 2005, 193, obr. 3). Podkovovitý objekt má analogický půdorys, jaký známe u hrnčířských pecí z Moravy, např́íklad pece z Kroměřiže - Milíčova náměstí, Jihlavy - Křížové ulice, Brna - Kapucínského náměstí, ze Starého Města u Uherského Hradiště a Mstěnic (Zatloukal 2000, 62-64; Procházka 2015 s další literaturou). Tento typ pecí byl rozšířen v oblastech západní Evropy (Francie, Belgie, Nizozemí, Německo) v 11. až 14. století. V Německu a Rakousku se označují jako liegender Ofen mit Mittelzunge (Heege 2007, 8-9). K peci z Vícova lze jako blízkou analogii uvést keramickou pec z Amstettenu
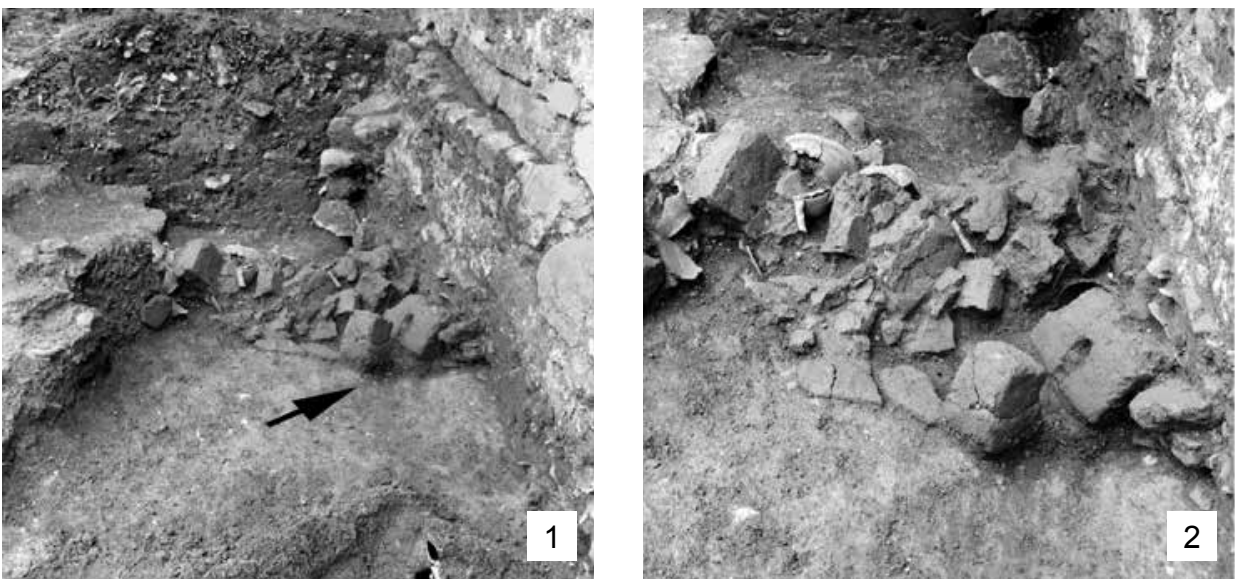

Obr. 21. Hliněné kvádry za ústím topeniště hrnčířské pece z Bakova nad Jizerou. 1 - celkový pohled na ústí pece, 2 - detail hliněných kvádrů. Foto digitální archiv AV ČR v Praze.

Abb. 21. Lehmquader hinter der Mündung der Feuerung des Töpferofens aus Bakov nad Jizerou. 1 - Gesamtansicht auf die Ofenmündung, 2 - Detail der Lehmquader. Foto digitales Archiv der Tschechische Akademie der Wissenschaften in Prag.

v Dolním Rakousku, která má podobný půdorys (Scharrer 1994, 133; 2000, 71-72; Heege 2007, 11, Abb. 18). Nálezová situace z Vícova u Přeštic, kde je tamní osídlení datováno, včetně nálezu tohoto objektu, již do přelomu 12. a 13. století, by však vyžadovala podrobnější zhodnocení. Zatím nebylo zjištěno, zda nález objektu na sídlišti doprovází další doklady primární hrnčířské výroby, především charakteristická stř̌epiště (Varadzin 2010, 69).

\section{Další typy novověkých pecí - pece kasselského typu a typ Piccolpasso}

Až do raného novověku nepozorujeme výrazné technologické změny v konstrukci pecí (srov. Heege 2007; 2013). V Čechách se raně novověké pece tvarově neodlišují od jednoprostorových vertikálních nebo horizontálních pecí (Tábor - náměstí Mikuláše z Husi čp. 44, Berounulice Politických vězňů p. č. 296, Česká ulice čp. 56). Jsou však již výhradně stavěny z cihel.

Diagonální horizontální pece se zahloubeným topeništěm a vyvýšeným prostorem bývají považovány za předstupeň tzv. kasselských pecí rozšířených v Evropě i u nás v 19. století (Scheufler-Plicková 1966, 11). Ty se používaly na výpal stavební keramiky v okolí Kasselu. Kasselské pece se vyznačují nízko položeným topeništěm odděleným od peciště vertikální přepážkou stěnou z kamenů nebo cihel s topnými otvory ve stěně, horizontální nebo téměř horizontálně položenou vypalovací komorou s plochým nebo mírně šikmým dnem, na jejímž konci se mohl nacházet komín. Pece mají protáhlý obdélný či oválný (vřetenovitý) půdorys a konstrukce je často zhotovena $\mathrm{z}$ cihel. $\mathrm{V}$ Německu se především používaly na výrobu hrnčiny a kamenin. 


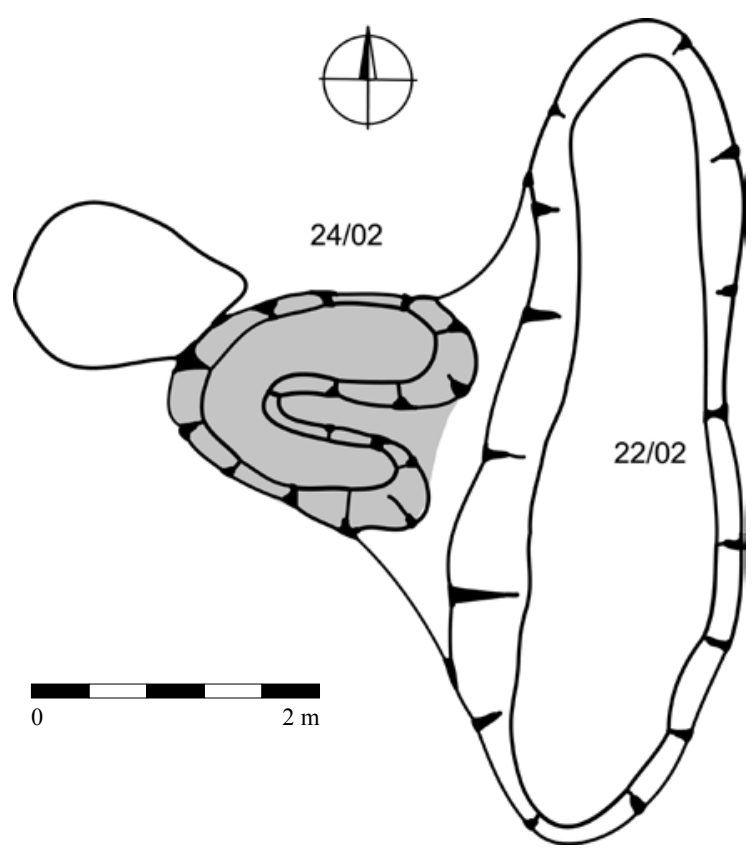

Obr. 22. Hrnčířská pec z Vícova u Přeštic. Podle Pícka-Tetour 2005, obr. 3, upravil L. Čapek. Abb. 22. Töpferofen aus Vícov u Přeštic. Nach Pícka-Tetour 2005, Abb. 3, bearbeitet von L. Čapek.

Nejstarší př́íklady tohoto typu jsou doloženy ve druhé polovině 18. století (Heege 2007, 21-22; 2013, 289; Kaltenberger 2009, 256-257).

V Čechách není dosud spolehlivě doložena žádná archeologicky zkoumaná pec kasselského typu. Ty se patrně vyvinuly z pecí s diagonálním tahem plamene. Mezi nejmladší archeologicky zkoumanou pec, která snad může být vývojovým předstupněm kasselské pece, náleží hrnčířská pec č. 5 z Chomutova - Farského ulice. Tato pec měla přibližně oválný tvar a byla vystavěná ze smíšeného zdiva. Z čelní strany pece se nacházela kamenná zed' (snad existence vertikální přepážky?), jejíž líc byl vyzděn z cihel. Před ní se nacházela zahloubená oválná předpecní jáma obsahující množství uhlíků. Přibližně uprostřed čelní zdi se nacházel dělicí pilír, který mohl rozdělovat prostor pece na dva topné kanály (obr. 23). Jiné dělení vypalovacího prostoru nebylo zjištěno. Pec byla používána do 16. až první poloviny 17. století. Vypalovala se v ní jak užitková, tak i kamnářská keramika. Některé keramické zlomky byly glazovány (Derner-Volf 2008, 174-175, obr. 4-6).

Další typ novověké pece představují pece typu Piccolpasso. Jde o vertikální pec pravidelného obdélníkovitého půdorysu. Její kořeny je možné hledat v římsko-mediteránním prostředí (nálezy jsou doloženy v Itálii, Španělsku a jižní Francii). Její název byl odvozen od jména Cypriana Durantina Piccolpassa, jenž pec popsal a nakreslil ve své práci I tre libri dell'arte del vasajo (Tři knihy o hrnčířském umění), která vyšla v Římě v roce 1558 (De Minicis-Delsette 1879). $\mathrm{K}$ rozšíření tohoto typu pece v oblastech severně od Alp došlo kolem roku 1500 a úzce souvisí s migrací italských hrnčířru (výrobců majolik) z Apeninského poloostrova. V jižním Německu, Rakousku a Švýcarsku, kde jsou tyto pece doloženy již od poloviny 16. století, se používaly jak k výrobě majolik, tak výpalu běžné hrnčiny (Heege 2013, 281-282). Po konstrukčních úpravách se staly rozšířeným typem pece, který sloužil k výrobě evropských fajánsí a užíval se až do 19. století. Pece se vyznačovaly dlouhým topeništěm po celé délce pece, nad nímž se nacházela 
vyvýšená podlaha nesená na prŕíných obloucích a klenutý vypalovací prostor s kouřovými otvory v horní části klenby (Heege 2007, 5-7; 2013, 282).

V Čechách dosud nebyl tento typ pece nalezen, jelikož zde dlouhodobě nefungovalo žádné významné centrum vyrábějící majoliku či fajáns. Na výrobu fajánsí se specializovali pouze novokřtěnci (habáni) na jižní Moravě (Pajer 1983; 2001; 2006). V rámci výzkumů habánských lokalit, které vedl H. Landsfeld, byla ve 40. letech 20. století odhalena pec v Ostrožské Nové Vsi. Nález se typově blíží pecím italským typu Piccolpasso, a to nejen svým pravoúhlým půdorysem, vertikálním členěním prostorů, ale i finálním produktem, jímž byla fajáns (Pajer 1998, 164-166; 2006, 110-111; 2007, 231-232, obr. 3-5).

\section{7 „Archeologie nenalézaného“ - drobné konstrukční detaily a jejich analogie}

U žádné hrnčířské pece z Čech nebyl doložen rošt, který by rozděloval topeniště a vypalovací prostor, ani nejsou zaznamenány dělicí prvky, např́íklad v podobě středového hliněného sloupu nebo soklu (vyjma diskutabilního nálezu výrobního zařízení z Vícova). Přesto nelze existenci roštů u hrnčířských pecí zcela vyloučit. Rošty patří do symptomatické kategorie „archeologie nenalézaného“. Příklady ze zahraničí ukazují, že v řadě případů rošt nebyl pevně připojen v rámci konstrukce pece. Máme doloženu existenci výměnných mobilních roštů (srov. Heege 2007, 5, s řadou příkladů). Chybějící rošty mohly být odstraněny společně s keramickou vsádkou, nebo zničeny při neodborně vedeném výzkumu.

Při rozboru několika hrnčířských pecí jsme si povšimli zajímavých konstrukčních detailů, které stojí za pozornost a jimž dosavadní bádání nevěnovalo větší pozornost. Při rozboru

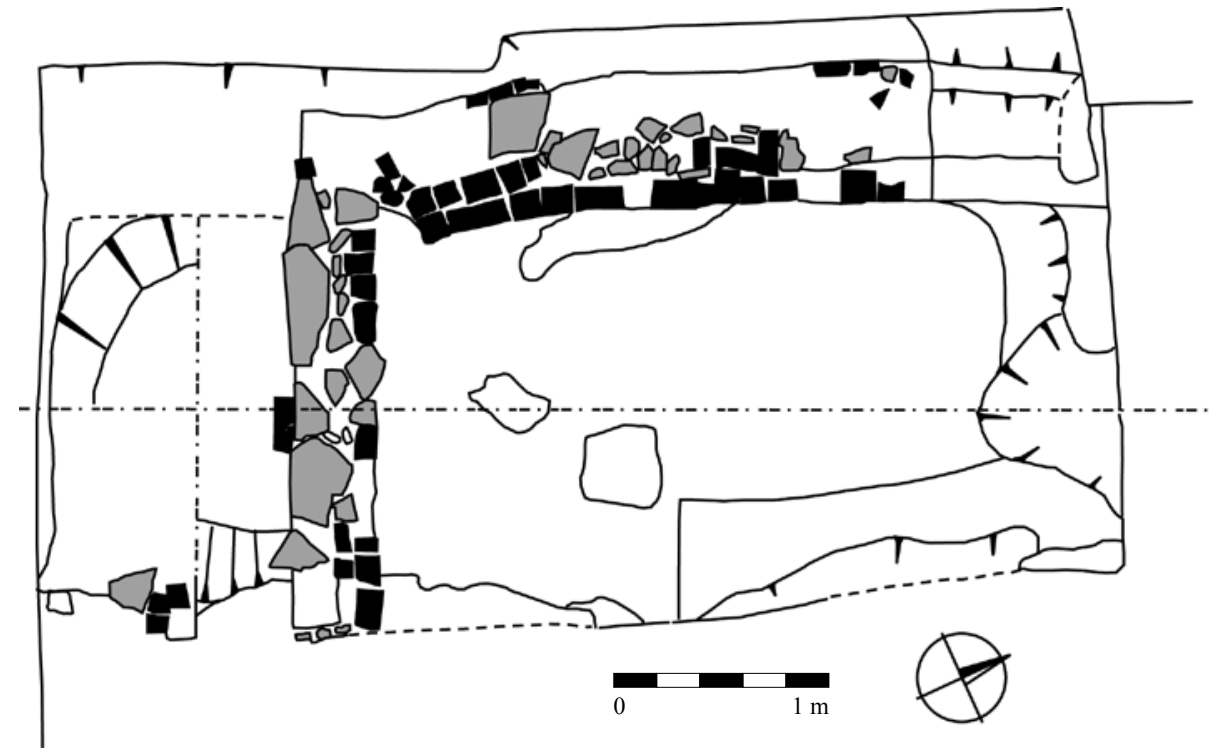

Obr. 23. Hrnčířská pec z Chomutova - Farského ulice. Podle Derner-Volf 2008, obr. 4, upravil L. Čapek. Abb. 23. Töpferofen aus Chomutov - Farského-Str. Nach Derner-Volf 2008, Abb. 4, bearbeitet von L. Čapek.

pece z Bakova nad Jizerou si nelze nepovšimnout drobných konstrukčních prvků uvnitř pece. U topeniště se nacházely dva hliněné vypálené kvádry, které byly L. Hrdličkou interpretovány jako pozůstatek ostění topného otvoru. Hliněné kvádry jsou patrné zejména na archivních fotografiích z výzkumu (obr. 21). Nabízí se však i jiná interpretace jejich funkce. Hliněné kvádry, které jsou umístěny za ústím topného otvoru, mohly vytvářet jakousi protipožární přepážku chránící vsádku 
před př́mým kontaktem s plamenem $\mathrm{z}$ topeniště. Zároveň mohly v peci sloužit k rozvodu plamene do více tahů. Podobné př́íklady hliněných sloupků za ústím vypalovacího otvoru známe z nálezů pecí v západní i východní Evropě, kde fungovaly na principu protipožárního roštu. V německé literatuře se označují jako Tonsäule (Heege 2007, 4, 7; Vágner 2002, 328-329; Kock 2004, 6-8). Zajímavý příklad konstrukčního řešení nabízí zrekonstruovaná hrnčířská pec v Brühlu (Severní Porýní-Vestfálsko), která pochází z druhé poloviny 13. století. U ní byly nalezeny dva hliněné sloupky při ústí vypalovacího otvoru (obr. 24), jejichž funkce spočívala v rozvodu plamene do tří směrů, který prostupoval pecí po celé délce šikmo vzhůru a byl odveden kouřovým otvorem v kupoli pece na straně protilehlé k vypalovacímu otvoru (Ocklenburg 1997, Abb. 118).

Podobně jako hliněné kvádry mohly fungovat v keramické peci i cihly. Zajímavé doklady užití cihel před ústím vypalovacího otvoru, jejichž funkce spočívala v rozvádění plamene do více tahů, byly pozorovány etnograficky u pecí z konce 19. století. Např́íklad ve Stoobu v Burgenlandu v Dolním Rakousku jsou u pecí s keramickými klenbami doloženy tzv. Graady, středové sokly z cihel, jež sloužily jako topné kanály, tzv. Graadloch (Bünker 1903).

Další konstrukční detaily souvisejí s konstrukcí kleneb z keramických nádob. U pecí s keramickou klenbou se ukazuje, že ne všechny nádoby mohly být zapojeny do konstrukce klenby. Nabízí se i jiný způsob jejich užití při řešení vnitřního vypalovacího prostoru, kde nádoby omazané hlínou mohly posloužit k vytvoření tzv. protipožární přepážky, vertikální formy roštu, nebo rozváděly plamen do více tahů. Jediný př́íklad, kde je doloženo, že keramické nádoby a kachle byly opakovaně používány pro konstrukci kanálů (tahů), představuje pec č. VII z výzkumu na náměstí Republiky v Praze - Novém Městě (Kašpar-Žegklitz 2009, 80-81; Volf 2014, 27). Jistou indicii pak nabízí nález pece z Plzně - Lochotínské ulice, kde bylo zjištěno, že ne všechny nádoby byly použity do konstrukce klenby. Prokazatelně se také nejednalo o pozůstatek jedné vsádky. Tamní nálezová situace však byla silně destruovaná. Zlomky pohárovitých kachlů byly nalezeny v severozápadní části sondy pod destrukcí stěn z kamenů a cihel, kterou byl po rozpadu

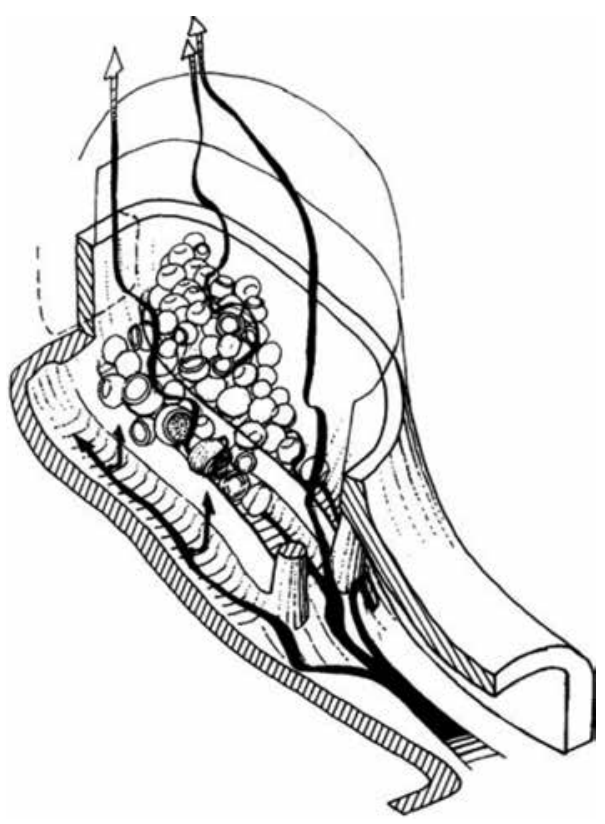

Obr. 24. Rekonstrukce keramické pece z Brühlu (Severní Porýní-Vestfálsko) s hliněnými sloupky při ústí topeniště. Podle Ocklenburg 1997, Abb. 118.

Abb. 24. Rekonstruktion des Keramikofens aus Brühl (Nordrhein-Westfalen) mit Lehmsäulen an der Mündung der Feuerung. Nach Ocklenburg 1997, Abb. 118. klenby pece pravděpodobně vyplněn přístup $\mathrm{k}$ topeništi. Zhroucení vnějších stěn vytvořilo rozsáhlý sut'ový kužel, který vyplnil prostor mezi topeništěm a vypalovacím prostorem, kde nebylo možné rozlišit, zda kachle tvořily i vnitřní členění vypalovacího prostoru (Doubová-Nechvátal 1996, 65). U pece z Plzně by bylo žádoucí podrobnější studium nálezové situace, bohužel stav dokumentace (pouze jediný publikovaný půdorys pece a několik fotografií z výzkumu) neumožňuje provést detailní analýzu.

Pokud pohlédneme do zahraničí, obdobná řešení týkající se zapojení keramických nádob do vnitřních konstrukcí nalezneme u řady pecí v západní i střední Evropě. Spojené keramické nádoby omazané hlínou mohly vytvářet středový sokl - jazyk a rozdělovat vnitřní prostor do více tahů. Doloženy jsou v jižním Bavorsku (Gammelsdorf) a zejména pak v Rakousku (Amstetten, Hainburg, St. Pölten, Mautern, Tulln), kde je středový sokl pecí sestaven z keramických nádob postavených dnem vzhůru a omazaný hlínou. Toto konstrukční řešení je doloženo od poloviny 14. století (Scharrer 1994; 2000, 70; 2001, 40-45; Heege 2007, 8, 10). Podobné 


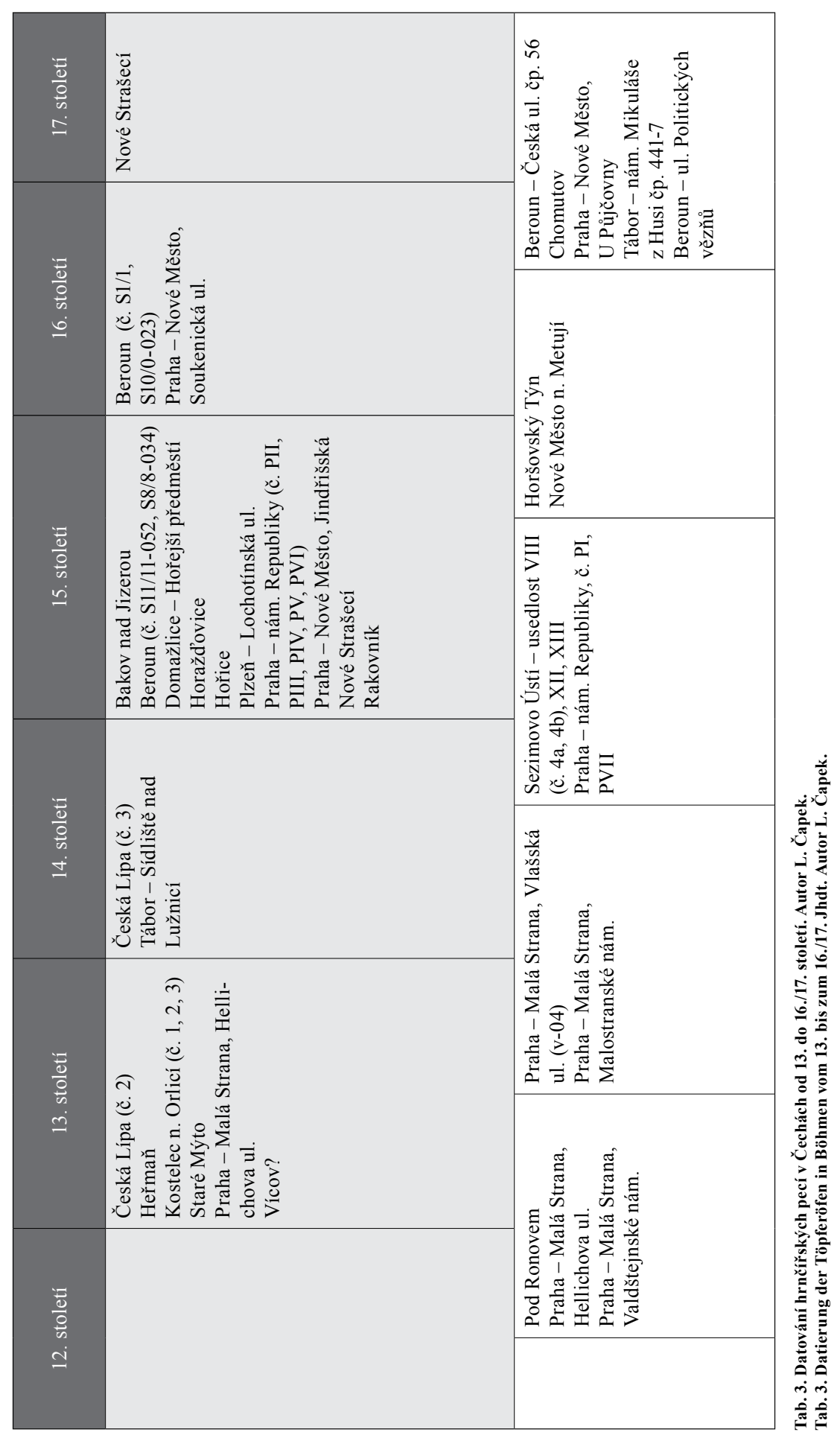


konstrukční řešení pece bylo doloženo i v belgickém Oudenaarde, kde byly hrncovité nádoby využity ke konstrukci středového sloupu (obr. 25; De Groote 1993, Abb. 21). S nálezy pecí se středovým jazykem se setkáváme v našem geografickém prostoru také na Moravě. Patří sem pece z Brna - Kapucínského náměstí, Jihlavy - Kř́ižové ulice, Kroměříže - Milíčova náměstí, Mstěnic a Starého Města - Na Kostelíku (Procházka 2015, Abb. 2-4, 6-7).

Nádoby obrácené dnem vzhůru mohly být využity jako podstavec pro mobilní rošt (Heege 2007, 69). Podobný způsob užití keramických nádob předpokládá i R. Procházka v souvislosti s nálezem pece z přelomu 13. a 14. století ze Starého Města u Uherského Hradiště (Procházka 2015, 218). U této pece pozorujeme spodní vrstvu nádob obrácených dnem vzhůru, které zřejmě tvořily základ, resp. podstavec pro novou vsádku. Navyšovaly stř̌ední sokl na podlaze a zároveň rozváděly tah plamene ve vypalovacím prostoru (Procházka 2015, 220). Původně byly interpretovány jako pozůstatek nevyzvednuté vsádky (Galuška 2003, 591-609). To může být také prrípad pece ze Starého Mýta, kde došlo ve vypalovací komoře k nálezu keramických nádob dvou různých skupin ve dvou řadách nad sebou. Starší skupina nádob hradištní tradice mohla tvořit spodní základový podstavec pro mladší skupinu vypalované keramiky, nebot', jak je uvedeno ve studii, ,soustřed'ovaly se nádoby původni vsádky více uprostřed pece a ostatni v různých polohách vyplňovaly vypalovaci prostor, včetně partii při stěnách" (Richter 1994, 146, 150).

Tento způsob užití kazových či starých nádob, které sloužily jako podklad na rovnání vsádky, je znám z etnografických výzkumů lidové (zakuřované) keramiky na Slovácku. Tyto nádoby, nazývané „kabáty“, tvořily podklad pro rovnání vsádky. Stavěly se na „dlážku“ dnem vzhůru zhruba $1 \mathrm{~cm}$ od sebe. Po dokončení výpalu zůstávaly v pecích a měnily se, když se měnila svým obsahem i vsádka (Snášil 1970, 332).

Tento způsob užití keramických nádob byl v posledních letech objeven při výzkumu pece v ulici Politických vězňů p. č. 296 v Berouně. Zde byla odhalena cihlová pec s vnějším kamenným pláštěm, kde na severní straně podél stěny byly nalezeny vyskládané hrnce do sebe složené dnem vzhůru spolu s kachli, které tvořily zřejmě podložky při výpalu. Nádoby byly značně deformované a př̀pálené (Benková 2014, 940).

Jiný způsob užití keramických nádob uvnitř pecí ukazují německé příklady ležatých pecí, kde se setkáváme s tzv. Topfsäule - sloupy tvořenými do sebe zasazenými hrnci a omazanými hlínou, které se nacházely za ústím topného otvoru a které vytvářely charakteristickou přepážku bránící prrímému kontaktu vsádky s ohněm (Heege 2007, 11-12, 19-20). Tento typ konstrukce je doložen např́íklad u archeologicky zkoumaných ležatých pecí v Dolním Sasku - Einbeck, pec

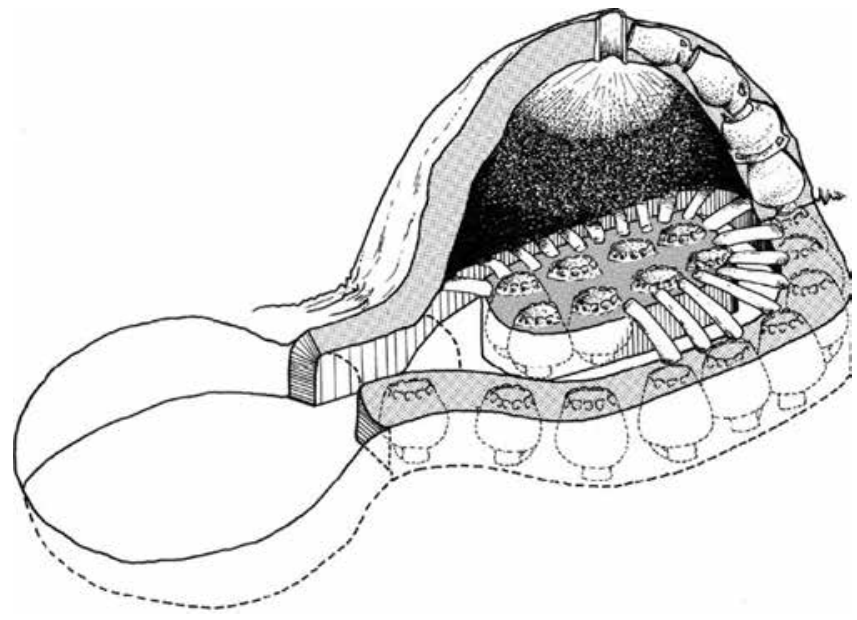

Obr. 25. Rekonstrukce vertikální pece z Oudenaarde (Belgie) se středovým sloupem tvořeným keramickými nádobami a paprsčitým hliněným roštem, něm. Schlitztenne. Podle De Groote 1993, Abb. 21.

Abb. 25. Rekonstruktion des vertikalen Ofens aus Oudenaarde (Belgien) mit aus Keramikgefäßen gebildeter Mittelsäule und Schlitztenne. Nach De Groote 1993, Abb. 21. 


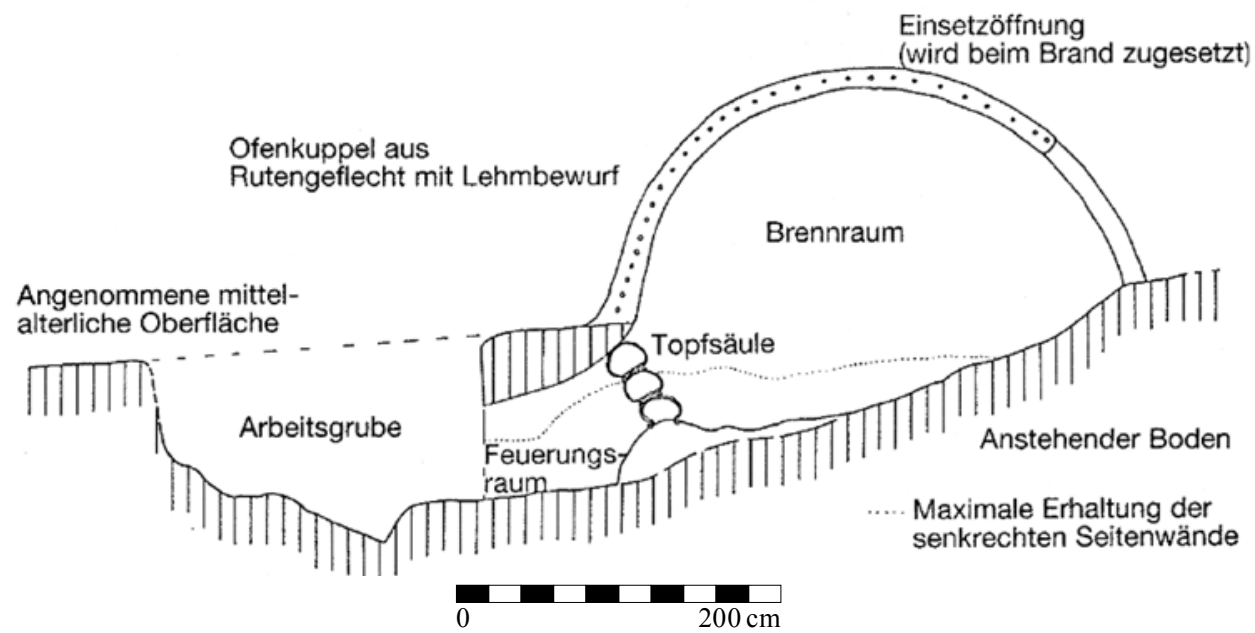

Obr. 26. Rekonstrukce pece z Einbecku (Dolní Sasko) kolem roku 1200, doloženy sloupky z keramických nádob, tzv. Topfsäule. Podle Heege 1997, 100-101, Fig. 4.

Abb. 26. Rekonstruktion eines Ofens aus Einbeck (Niedersachsen) um 1200, Topfsäule belegt. Nach Heege 1997, 100-101, Abb. 4.

č. 2 (obr. 26; Heege 1997, 100-101, Fig. 4), Coppengrave (Stephan 1981), Meklenbursku-Pomořansku - Granzin, Dümmer (obr. 27; Drews 1978-1979, 46-47; Engel 1952, 78-87, Abb. 1-2). Na obdobném principu zřejmě fungovaly i středové sloupy z keramických nádob u pece z města Winterthur (Švýcarsko), které navíc podpíraly oblouk horní konstrukce keramické klenby pece (Lehman 1992, 47; Heege 2007, 19, Abb. 41).

\section{Problematika datování hrnčířských pecí}

Problematice datování keramických pecí se u nás také nevěnovala dostatečná pozornost. Řada pecí je řazena do širokého intervalu datování, které se opírá především o keramický materiál nalezený v kontextu pecí. Přesnější datování by vyžadovalo podrobný vzájemný rozbor keramiky a stratigrafických vztahů, které jsou $\mathrm{v}$ př́ípadě řady pecí řešeny nedostatečně nebo vůbec. $Z$ různých důvodů nejsou v řadě př́ípadů stratigrafické vztahy $\mathrm{k}$ dispozici. $Z$ hlediska datování pecí je důležité zaznamenat zejména zvrstvení, do kterého je pec zahloubena (podrobně hodnoceno např. u pece v Bakově nad Jizerou - Hrdlička 1967, 521-522, nebo u pece v Táboře - Sídliště nad Lužnicí - Krajíc 1982, 269-271). Vrstvy s keramikou, do níž je pec zahloubena, poskytují datování terminus post quem a počátek hrnčiřské výroby. Dosud nebyly využity možnosti radiokarbonového datování pomocí uhlíku ${ }^{14} \mathrm{C}$, alespoň u novějších z objevených pecí (např. Kock 2004).

Keramika z kontextu pecí pochází přímo z vypalovacího prostoru na dně pece, nebo z výplně předpecní jámy, př́ipadně $\mathrm{z}$ destrukce klenby, kde je promíšena společně s mazanicí. Datování keramických pecí znesnadňují i nálezy intruzí, a to bud' v podobě reziduální nebo infiltrované keramiky, nejčastěji v nekrytých částech pecí, zejména předpecních jámách. Tam se po zániku pecí dostal keramický materiál, který pocházel ze širšího okolí (Richter 1994, 154).

Ve vzácných případech máme doloženy nálezy pecí se zcela nebo zčásti zachovanou vsádkou. Nálezy vsádek jsou doloženy v Čáslavi (Čermák 1905), Domažlicích - pec č. 21 (Procházka 1983, 7), Starém Mýtě (Richter 1994), Plzni - Lochotínské ulici (Doubová-Nechvátal 1996), Horaždovicích (Tetour 2002), Rakovníku (Blažková-Lomecká 2006), Žatci (Káčerik 2010) a Berouně - Hořejším předměstí, č. s. j. S8/8-034 a S11/11-052 (Vyšohlíd 2015; 2015a). 

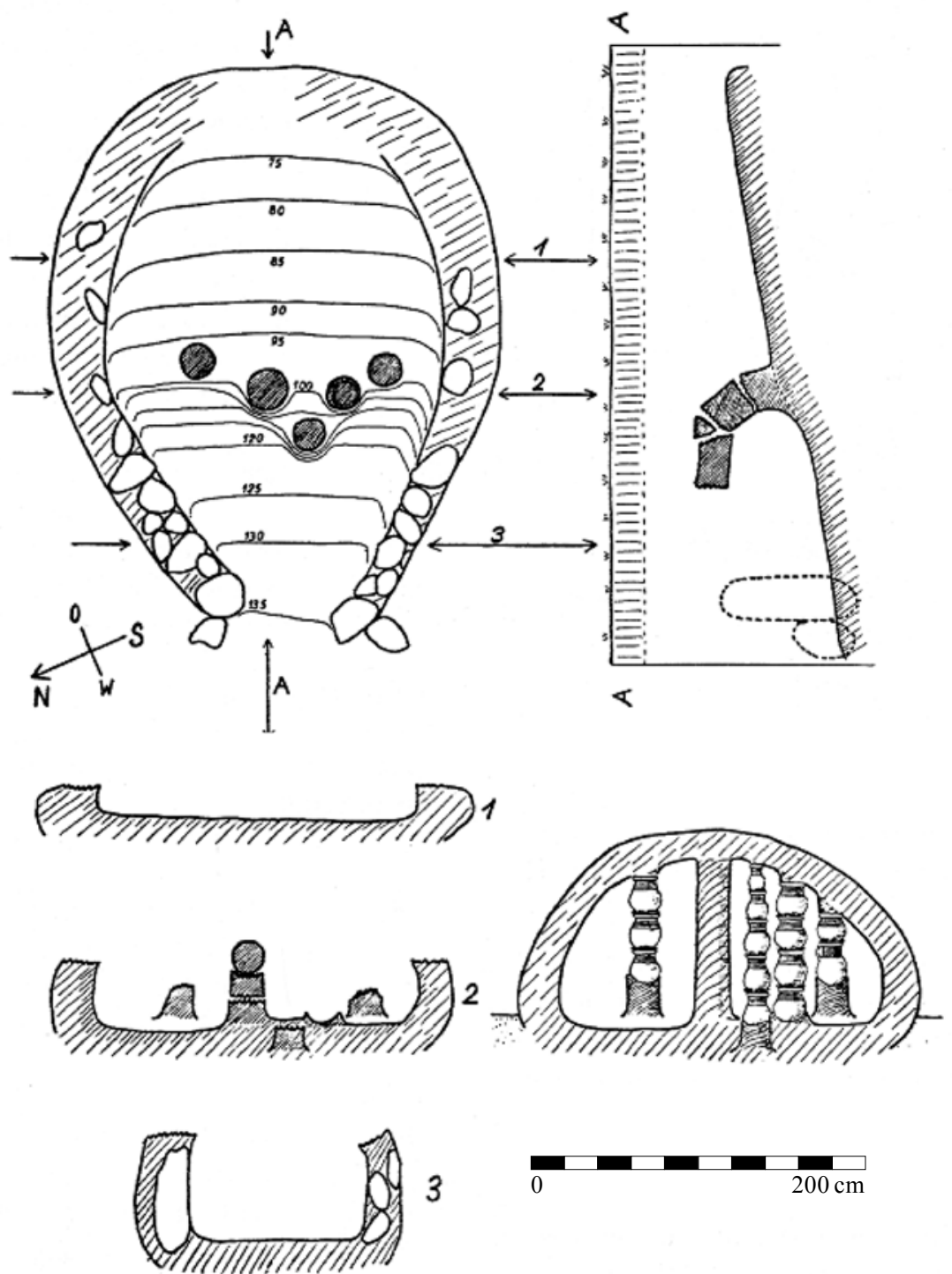

Obr. 27. Pec se středovými sloupky z hlíny a hrncovitých nádob oddělující topeniště od vypalovacího prostoru v Dümmer (Meklenbursko-Pomoří) z první poloviny 14. století. Podle Engel 1952, 78-87, Abb. 1-2.

Abb. 27. Ofen mit Topfsäule aus Lehm, durch welche die Feuerung vom Brennraum abgetrennt wird in Dümmer (Mecklenburg-Vorpommern) aus der ersten Hälfte des 14. Jhdts.. Nach Engel 1952, 78-87, Abb. 1-2.

Keramické vsádky uvnitř pecí představují z archeologického hlediska nálezové celky, které prošly krátkou post-depoziční historií. Nálezy vsádek jsou „uzkým časovým snímkem o tvorbě jedné nebo několika skupin keramického inventáře, poznamenané navíc individualitou výrobcư“ (Richter 1994, 145). Nevyzvednutá vsádka datuje dobu posledního výpalu pece po jejím uzavření. Jedná se o datování terminus ante quem, pec mohla fungovat již o několik desítek let dřive a mohla sloužit $\mathrm{k}$ několikanásobným a opakovaným výpalům již delší dobu. Není jasné, proč některé archeologicky doložené keramické vsádky zůstaly nevyzvednuty. Mohlo dojít k selhání výpalu a k následnému poboření stěn a kupole pece. V př́ípadě Starého Mýta se můžeme 
domnívat, že hrnčířské pracoviště bylo opuštěno v souvislosti se zánikem a přesunem městské lokace do nově založeného Vysokého Mýta (Richter 1994).

Bohužel ani keramickým vsádkám nebyla věnována dostatečná pozornost, vyjma př́ikladu ze Starého Mýta a Plzně - Lochotínské ulice, kde je ovšem vsádka promíšena společně s keramikou, jež tvořila konstrukci klenby (Doubová-Nechvátal 1996, 46-49). Vypalovací prostor keramické pece byl zpravidla maximálně využit k nakládání co největšího počtu nádob obrácených dnem vzhůru v několika řadách nad sebou, aby byla plocha pece co nejefektivněji zaplněna (Zatloukal 2000, 60). V řadě př́ípadů se setkáváme se vsádkami, které představují jen malý zbytek původního naložení pece, a zpravidla se jedná o nedokonale vypálené nebo poškozené nádoby. Poškozených keramických zlomků v peci bylo také využito k vyplňování nejrůznějších dutin v okolí pece (srov. Procházka 2015, 220). U těchto sekundárně přemístěných zlomků nelze spolehlivě určit, k jaké hrnčiřrské peci skutečně náležely. Defektní zlomky keramiky mohly být recyklovány a použity jako vyrovnávací vrstvy (Zatloukal 2000, 63).

Pakliže je publikována keramika k nálezům pecí, jde především o hotové vypálené celé či zrekonstruované keramické nádoby. Žárem či jinak mechanicky poškozené nádoby a zlomky keramiky nejsou zpravidla blíže uváděny. Světlou výjimku v tomto směru představuje zhodnocení zlomkové keramiky pocházející ze střepišt' z výzkumu hrnčířských pecí na náměstí Republiky v Praze - Novém Městě (Volf 2014).

Nepř́iliš v literatuře diskutovaným tématem je otázka životnosti hrnčířských pecí. Některé experimentální studie z Velké Británie zmiňují, že životnost pece mohla být zhruba pět let. Díky užití trvanlivých materiálů v konstrukcích v pozdním středověku se životnost pecí mohla prodloužit na deset i více let (Musty 1974, 53). Archeologické výzkumy dokládají časté opravy konstrukcí hrnčířských pecí, zejména opravy hliněných kupolí (srov. Krajíc 1982, 272).

\section{Př́ŕodovědné fyzikálně-chemické analýzy}

Je překvapivé, že dosud nebyly analyzovány vzorky keramiky z nálezů hrnčířských pecí pomocí přírodovědných fyzikálně-chemických (petrografických) metod. Důležité je to zvláště v prŕípadech, kdy byla vedle keramiky v pecích, či pocházející ze střepišt' v okolí hrnčířského pracoviště, nalezena také hrnčířská surovina. Deponie hrnčířské suroviny - keramických jílů byly nalezeny ve Starém Městě, v Sezimově Ústí, Berouně, Hořovicích, Rakovníku, Kutné Hoře, České Lípě, Domažlicích a v Praze na Malé Straně.

V př́ípadě analýz keramiky postrádáme mikropetrografické analýzy výbrusů pomocí polarizačního mikroskopu, rentgenové fluorescenční a rentgenové difrakční analýzy pro určení chemicko-mineralogického složení ostřiva a pojiva v keramické hmotě, které by mohly přispět k určení provenience surovin a technologie výroby (např. Gregerová a kol. 2010). K provenienční srovnávací analýze se nabízí například studium červeně malované keramiky mezi hrnčířskými pracovišti v severních Čechách - Česká Lípa, Levín a center výroby na Malé Straně v Praze (Gabriel-Smetana 1983, 129-133; Havrda-Matějková 2014).

Dosud nebyly provedeny ani potřebné termické analýzy - jako diferenční termická analýza (DTA) nebo termogravimetrie (TGA), které sledují změny teploty a endotermní a exotermní reakce, které probíhají během výpalu. Tyto metody by rovněž mohly přispět k otázce principu a fungování výpalu v pecích a ke studiu změn atmosféry výpalu (oxidační/redukční), která byla kontrolována prostřednictvím otevírání a uzavírání otvorů pro odvod kouře. Způsob fungování výpalu ve stř̌edověkých pecích je tak výhradně založen na experimentálních pokusech (Bočková a kol. 2014, 132-135; Doležalová a kol. 2016, 19-20; v zahraničí např. Kock 2004), bez patřičného exaktního studia samotného keramického materiálu.

\section{Organizace hrnčířské výroby}

O organizaci hrnčířské výroby ve vrcholném a pozdním středověku máme velmi málo písemných pramenů. Profese jednotlivých hrnčířů se v nich objevují sporadicky. Ve starších 
obdobích od poloviny 11. až do konce 12. století vystupují jako hrnčíři na klášterních panstvích, od 13. století se s hrnčíři setkáváme ve městech, kde jsou od 14. a 15. století uváděni i se jmény, zaznamenanými v městských knihách. Známe je pod latinskými názvy jako figuli, lutifiguli, ollatores, figellatores, později německy jako Töpfer, Hafner. Teprve až v pozdním středověku se hrnčíři začali sdružovat do cechů, které lze považovat za organizační struktury, které měly mimo jiné dohlížet na určitou formu standardizace výroby hrnčiřů (srov. Nekuda-Reichertová 1968, 23; Winter 1906). Nejlépe je zaznamenán vývoj hrnčířského cechu na př́ikladu České Lípy - hrnčířské čtvrti pro období mladšího středověku a novověku (Gabriel-Panáček 2000, $16-23)$.

Hrnčířská pracoviště se ve vrcholném a pozdním středověku nacházela ve městech i na vesnicích. Datování hrnčířských pecí ukazuje na trend, kdy se venkovská a ještě značně podomácká výroba keramiky ve 13. století (srov. Varadzin 2010, 39-40) postupně v průběhu 13. a 14. století přesunula do měst. Svou roli zde hrála blízkost městského trhu a větší možnost odbytu keramických výrobků. Otázkou dalšího výzkumu zůstává, jaký vliv měl na domácí hrnčíře transfer technologií a inovace v keramické výrobě způsobené přítomností cizích komunit (kolonistů) při zakládání měst. V keramice můžeme vysledovat jisté technologické a morfologické vazby na oblasti, odkud osídlenci do měst přišli, například vazby jihomoravské keramiky na rakouské Podunají (Procházka-Peška 2007, 173), nebo podobnost světlé oxidační keramiky v severozápadních Čechách s keramikou v oblastech jihozápadního Německa (Klápště 1998, 146-146).

Ve městech se hrnčířské řemeslo koncentrovalo na okrajích zástavby poblíž hradeb nebo přímo $\mathrm{v}$ areálech předměstí, kam bylo vytěsňováno $\mathrm{v}$ souvislosti s protipožárními opatřeními a zároveň se mu zde nabízela lepší dostupnost hrnčířských surovin, jako např́íklad v Praze na Malé Straně (Havrda-Matějková 2014, 44-46). Zejména z městských a trhových knih známe dokonce i jména konkrétních hrnčířu obývajících jednotlivé městské čtvrti a areály předměstí, odtud jsou často odvozovány názvy jako Hrnčířské předměstí, Hrnčířská ulice apod. (NekudaReichtertová 1968, 22).

Z hlediska zastoupení a koncentrace hrnčířských pecí na venkovských a městských lokalitách a způsobu organizace hrnčířské výroby můžeme uvažovat podle D. Peacocka $(1982,8-9)$ o rozdělení hrnčirrských pracovišt' na několik skupin: 1) individualizované dilny jednotlivého výrobce-hrnčíře a jeho rodiny; 2) sdružené dílny, sdružující výrobu několika hrnčírư v rámci jednoho výrobního okrsku a 3) produkčni centra, koncentrované hrnčířské výroby vázané navíc na dostupnost vhodných surovin, hrnčířských jílů.

V řadě př́ípadů se setkáváme s jednotlivými nálezy pecí, které charakterizují individuální výrobu jedné domácnosti, odlišující se úzkou lokální škálou svých výrobků. Jednu pec mohlo ale používat i více hrnčírưo jak dokládá zmiňovaný příklad ze Starého Mýta, kde byly v jedné peci nalezeny rozdílné skupiny keramiky, dokládající výrobu dvou nebo několika hrnčírư působících $\mathrm{v}$ jedné či více dílnách, kteří své výrobky vypalovali společně. Díky nálezům domácí keramiky, vycházející ještě z hradištních tradic a vyspělé světlé oxidační keramiky, nelze vyloučit, že v jedné dílně mohli působit hrnčíři náležící ke skupině tzv. kolonistů. Taktéž zde mohli pracovat domácí hrnčíríi, kteří byli obeznámeni s technologií a tvarovým repertoárem nastupující kolonizační keramiky (Richter 1994, 150; srov. Varadzin 2010, 69).

Za sdružené dílny lze považovat pracoviště hrnčírů působících v Kostelci nad Orlicí a České Lípě, kde byla od druhé poloviny 13. století soustředěna produkce červeně malované keramiky. Na její výrobě se mohlo podílet několik hrnčířu s odlišnými tradicemi výpalu ve dvou různých typech hrnčířských pecí (Gabriel 1979; Gabriel-Panáček 2000). Charakteristickým příkladem sdružené dílny je Sezimovo Ústí, kde tamní hrnčířské pracoviště vytvářelo samostatný okrsek v rámci pravidelné zástavby předměstí a hrnčíři se zde specializovali na výrobu jednoho typu zboží. Šlo o redukční keramiku příznačnou pro 14. a počátek 15. století, do doby zániku předměstí v roce 1420 (Richter-Krajíc 2001).

Ke koncentraci hrnčířské výroby dochází zejména během 15. století. Svou významnou roli zde sehrál trh a rostoucí poptávka po větším objemu hrnčířských výrobků. To mohlo vést k rychlejšímu prosazení dokonalejšího konstrukčního řešení jednoprostorových horizontálních pecí 
s kontrolovaným vedením plamene a zvětšení vypalovacího prostoru a kapacity pecí. Rozššření horizontálních pecí je obecně spojeno se sériovou výrobou keramiky, která se vyznačovala vysokou standardizovanou kvalitou nejen keramické suroviny, ale i výpalu. V Německu k této změně došlo v souvislosti s výrobou kamenin (podobně Vágner 2002, 335; Heege 2007), u nás v souvislosti s technologicky vyspělejšími hrnčinami - světlou červeně malovanou a redukční (zakuřovanou) keramikou (k tomu např. Vařeka 1998) a na Moravě s loštickou keramikou (Goš 1983).

Mezi velká centra koncentrované hrnčiřské výroby lze zařadit, byt's určitými výhradami, hrnčířská pracoviště fungující v Praze, na Malé Straně. Zde jsou nálezy hrnčířských pecí více atomizované, ale soustř̌eděné $\mathrm{v}$ rámci jednoho městského areálu, kde hrnčířská výroba má dlouholetou tradici, snad již z konce 12. století. Hrnčíři zde vyráběli více druhů zboží a také červeně malovanou keramiku (Havrda-Matějková 2014; srov. Žegklitz 1990, 221-222). Dalším podobným centrem v Praze bylo Nové Město, kde byla výroba soustředěna ve 14 . a 15. století kolem dnešního náměstí Republiky a Truhlářské ulice - dříve Hrnčířské (Žegklitz 1990, 221; Kašpar-Žegklitz 2009; Volf 2016). Hrnčíři zde produkovali jak oxidační, tak i redukční keramiku. Běžné bylo glazování vnitřních povrchů nádob (Volf 2016, 42-46). Další produkční centra se nacházela v areálech předměstí, například v Berouně, kde se hrnčíři v 15. století specializovali na výrobu pozdně stř̌edověkého redukčního zboží a později inklinovali od poloviny 16. století k produkci raně novověkého oxidačního, tzv. berounského zboží (Vyšohlíd 2015; Vařeka 2004). Další archeologicky doložené produkční centrum fungovalo v Domažlicích na Hořejším předměstí. Ve více pecích byla doložena výroba jak redukční keramiky (ca 20\%), tak i světlého oxidačního zboží ( $80 \%$ ) s červeným malováním. Jde o výrobní areál datovaný do 15 . až první poloviny 17. století (Procházka 1983, 4-7).

O umístění koncentrované hrnčířské výroby svědčí také prostorová vazba na vhodné zdroje potenciálních surovin v zázemí, které jsou archeologicky doložené v podobě deponií hrnčířských hlín - jílů, nebo objektů ke skladování jílů v blízkosti pecí (Praha - Malá Strana, Beroun, Domažlice, Česká Lípa). U těchto center se ukazuje úzká vazba hrnčířské výroby na lokální, ale i regionální trh. Např́íklad berounští hrnčíři našli odbyt svých výrobků jak na místním, tak regionálním trhu. Otázkou zůstává, zda koncentrovanou hrnčířskou výrobu projevující se vyšším počtem nálezů pecí lze přímo označit za produkční centra (podobného typu, jaké fungovaly např́iklad v Porýní, např. Weiser 2003; Heege 2007), když neznáme okruh distribuce zboží pocházejícího z těchto dílen, vyjma zmiňovaného Berouna, odkud se výrobky známé jako berounské zboží1 ${ }^{10}$ dostávaly až na městský trh v Praze (Blažková-Žegklitz 2016, 149).

\section{Zhodnocení nálezů středověkých a raně novověkých hrnčířských pecí}

V případě nálezů keramických pecí z Čech se ukazuje vývoj, který postupně směřuje od jednoprostorových vertikálních $\mathrm{k}$ jednoprostorovým horizontálním pecím a k pecím s diagonálním tahem plamene.

Jednoprostorové vertikální pece patří mezi nejstarší archeologicky doložené typy hrnčířských pecí v Čechách. Nejstarší pochází z počátku 13. století, pomineme-li dosud nenalezené doklady pro jámový výpal či tzv. milířovité pece (srov. Varadzin 2010, 23; Snášil 1970). Jednoprostorové vertikální pece byly rozšířené jak v Čechách, tak na Moravě v průběhu 13. a 14. století a objevovaly se i v 15. století, případně ještě v mladším raně novověkém období (např. Procházka 2015, 219; v Čechách doložena na př́íkladech pecí z Tábora, Berouna). Naopak v západní Evropě byly tyto pece v provozu jen do 14. století (Heege 2007, 5). U pozdně středověkých pecí došlo k proměně konstrukce, kdy hliněné pece nahradily konstrukce $\mathrm{z}$ trvanlivějších materiálů (kámen a cihly). V mladším horizontu 16. až 17. století měly pece již základovou konstrukci, podlahu a stěny tvořené $\mathrm{z}$ cihel.

10 Současné názory na otázku keramiku tzv. berounského zboží vedou k závěrům, že center výroby malované keramiky na bílé nástřepí překrývající cihlově pálený střep bylo více (Žegklitz 2015, 122, obr. 23; Preusz 2017, 160-162). 


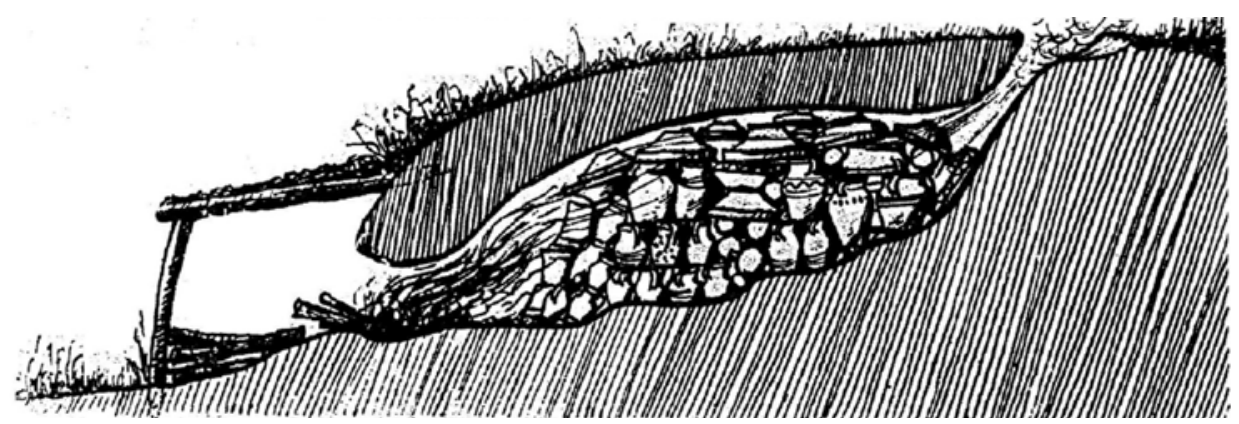

Obr. 28. Rekonstrukce horizontální jednoprostorové pece z 19. století z Pozdišovic. Podle Plicková $1959,39$. Abb. 28. Rekonstruktion eines horizonbtalen Einkammerofens aus dem 19. Jhdt. aus Pozdišovice. Nach Plicková $1959,39$.

S jednoprostorovými horizontálními pecemi se na našem území setkáváme sporadicky již od konce 13. a počátku 14. století, k jejich hlavnímu rozšíření dochází až v 15. století. Během té doby dochází k pozvolnému zvětšení jejich velikosti z potřeby dosáhnout větší kapacity a většího objemu keramické produkce (Procházka 2015, 219). Otázkou dalšího výzkumu zůstává, nakolik se na jejich rozšíření podílely kulturní kontakty či transfer technologií a zavádění inovací ve výrobě. Zejména jde o vlivy ze západní Evropy, z oblasti Porýní, kde se př́klady nejstarších horizontálních pecí (liegende Öfen) objevují již v merovejském a karolinském období a ve 12. a 13. století byly dále rozšiřovány do oblastí střední a východní Evropy na někdejší slovanská území (Janssen 1987, 107-119; Gaimster 1997, 41-44; Vágner 2002, 317-318; Weiser 2003, 19-21; Heege 2007, 7; Biermann-Pust 2011, 135, 159-160). Nejstarší př́íklady u nás, vyjma atypické pece č. 3 z Kostelce nad Orlicí, jsou spojené s výrobou červeně malované keramiky př́ikladem je Česká Lípa (Gabriel 1979).

$\mathrm{S}$ jednoprostorovými horizontálními pecemi, případně s pecemi s diagonálním vedením plamene se setkáváme až do 19. století. Etnograficky jsou doloženy např́íklad na východním Slovensku (obr. 28; Plicková 1959, 39).

\section{Závěr a diskuse}

Tradiční typologie pecí vytvářela klasifikaci pecí podle toho, zda bylo odděleno topeniště od vypalovacího prostoru, a nezohledňovala termodynamické vlastnosti, mezi něž patř́ způsob vedení plamene $\mathrm{v}$ peci ve vertikálním, horizontálním nebo diagonálním směru. Teprve až v posledních letech na základě publikací pecí a vytváření jejich podrobné typologie, především v západoevropském prostředí (Weiser 2003, Heege 2007; Vágner 2002), došlo k novému přehodnocení některých nálezů hrnčířských pecí na Moravě (Procházka 2015). V Čechách se pecím dosud nedostalo náležité pozornosti vyjma studie L. Varadzina (Varadzin 2010).

Oproti nálezům hrnčířských pecí na Moravě, ale i jinde v západní a východní části Evropy, se v Čechách setkáváme $\mathrm{s}$ jednoduššími konstrukčními variantami jednoprostorových vertikálních a horizontálních pecí. Prokazatelně chybí doklady pro pece dvouprostorové, pro něž je charakteristické oddělení pomocí vertikálního či horizontálního roštu (srov. Varadzin 2010; Procházka 2015; Vágner 2002; Heege 2007). Výjimku snad představuje pec se středovým jazykem z Vícova u Přsštic, která podle tvaru půdorysu má analogicky blízko k podobným typům pecí z Moravy nebo z Rakouska. Více se v Čechách, na rozdíl od Moravy, objevují pece s keramickou klenbou. Otázkou zůstává, zda hrnce spojované s jejich užitím v konstrukci kleneb pecí nemohly fungovat i jinak v rámci vypalovací komory na způsob tzv. kabátů, jak je známe z etnografie, či zda nemohly tvořit středový sloup/jazyk a základ pro nějakou formu mobilního roštu. Pouze $\mathrm{v}$ ojedinělých případech máme $\mathrm{u}$ jednoprostorových horizontálních pecí či pecí s diagonálním vedením plamene doklady pro rozdělení vnitřního prostoru pomocí středových 
sloupků z hliněných kvádrů či cihel (tzv. štendrů), jejichž funkce spočívala v rozvedení plamene do dvou i více tahů.

V Čechách dosud nedošlo k objevu nejmladší skupiny pecí, kam v západoevropské terminologii patří typ kasselské pece nebo typ Piccolpasso. Tyto pece ovšem souvisí s výrobou kamenin a fajánsí, které se na území Čech s největší pravděpodobností nevyráběly a byly do Čech importovány jako hotové výrobky z produkčních center výroby kamenin, zejména v Sasku a Lužici, a výroby fajánsí na jižní Moravě. Dosud nevytěženým pramenem, který by mohl přispět ke konstrukční podobě nejmladší skupiny novověkých pecí, jsou stavební plány z přestaveb hrnčířských dílen zejména z 19. století. Nelze vyloučit, že se v nich mohou nalézat i další konstrukční podoby pecí, které obohatí naše poznání raně novověkých výrobních zařízení.

Studie je výstupem projektu NAKI II - Vrcholně středověká keramika jako součást movitého kulturního dědictví, č. projektu DG18P02OVV020.

\section{Prameny}

PICCOLPASSO, C. D., 1548: I tre libri dell'arte del vasajo (De Minicis, R.-Delsette, G., edd.). Roma 1857. Dostupné z: https://archive.org/details/itrelibridellar00lazzgoog/page/n7, cit. 3. 12. 2018.

\section{Literatura}

BENKOVÁ, I., 2014: Beroun, okr. Beroun, Ul. Politických vězňů, st. p. č. 296, ASČ 18, 937-941.

BIERMANN, F., 1998: Der mittelalterliche Töpferofen von Göttin, Stadt Brandenburg an der Havel. Ein Beitrag zu Keramik- und Siedlungsforschung der Zauche, Veröffentlichungen des Brandenburgischen Landesmuseums für Ur- und Frühgeschichte 32, 189-236.

BIERMANN, F.-PUST, A., 2011: Keramikbrand und Töpferöfen im nordwestslawischen Raum, Offa - Berichte und Mitteilungen zur Urgeschichte, Frühgeschichte und Mittelalterarchäologie 65/66 2008/2009, $135-164$.

BLAŽKOVÁ, K.-LOMECKÁ, J., 2006: Záchranné archeologické výzkumy pozdně středověké hrnčířské pece a studny v Rakovníku, ASČ 10, 913-926.

BLAŽKOVÁ, G.-ŽEGKLITZ, J., 2016: Současný stav poznání raně novověké keramiky v Praze. In: Praha archeologická. Archaeologia Pragensia - Supplementum 3 (Boháčová, I.-Šmolíková, M., edd.), 147178. Praha.

BOČKOVÁ, Z. a kol., 2014: Bočková, Z.-Doležalová, K.-Kochan, Š.-Mazáčková, J.-Slavíček, K.-Těsnohlídek, J., Experimentální výroba keramiky v Panské Lhotě - Experimentelle Herstellung von Keramik in Panská Lhota, AH 39, 119-137.

BÖTTCHER, G.-BÖTTCHER, G., 1997: Mögliche Brennverfahren und der Magerungsgehalt im Masseversatz bei der Herstellung slawischer Irdenware. In: Experimentelle Archäologie in Deutschland: Bilanz 1996, Archäologische Mitteilungen aus Nordwestdeutschland, Beiheft 18 (Fansa, M., ed.), 87-93. Oldenburg.

BÜNKER, J. R., 1903: Die Hafneröfen in Stoob, Mittheilungen der Anthropologischen Gesellschaft in Wien 33, 329-335.

ČERMÁK, K., 1905: Hrnčířské dílny v Čáslavi v době renaissanční, Památky archeologické a místopisné 21 , č. $1,567-572$.

ČIHÁKOVÁ, J.-ZAVŘEL, J., 1993: Malostranské náměstí. In: Dragoun, Z. a kol., Archeologický výzkum v Praze v letech 1990-199. Pražský sborník historický 26, 198-200. Praha.

DE GROOTE, K., 1993: De middeleeuwse ambachtelijke wijk van Pamele (stad Oudenaarde, Oost-Vlaanderen). Het onderzoek in het Huis de Lalaing, 1. De pottenbakkersovens, Archeologie in Vlaanderen 3, 359-399.

DERNER, K.-VOLF, M., 2009: Objev torza renesanční hrnčiřské pece a střepiště v Chomutově. In: Archeologické výzkumy v severozápadních Čechách za rok 2008 (Kuljaceva Hlavová, J.-Sýkora, M., edd.), 171-181. Most.

DOLEŽALOVÁ, K.-SLAVÍČEK, K.-MAZÁČKOVÁ, J., 2016: Čtyři sezóny výzkumu a experimentální výroby vrcholně a pozdně středověké keramiky na vědecko-výzkumné stanici v Panské Lhotě. Dissertationes archaeologicae Brunenses/Pragensesque - Supplementum 3, 18-24. Brno. 
DOUBOVÁ, M.-NECHVÁTAL, B., 1996: Středověká hrnčířská pec v Plzni-Lochotínské ulici - Mittelalterlicher Töpferofen in Pilsen-Lochotínská Strasse. In: Sborník Západočeského muzea v Plzni - Historie 13, 41-74. Plzeň.

DREWS, G., 1978-1979: Entwicklung der Keramik-Brennöfen, Acta Praehistorica et Archeologica 9-10, $33-48$.

ENGEL, F., 1952: Die mittelalterlichen Topferöfen von Dümmer und Granzin, Hammarburg 3, $78-87$.

FRÝDA, F., 1992: Středověká hrnčířská pec z Horšovského Týna - Ein mittelalterlicher Topferofen aus Bischofteintz (Horšovský Týn). In: Sborník Západočeského muzea v Plzni - Historie 8, 187-193. Plzeň.

GABRIEL, F., 1979: Počátky hrnčířství v České Lípě - Die Anfänge der Töpferei in Česká Lípa, AH 4, 257-265.

- 1981: Pottery workshops at the town of Česká-Lípa, Bohemia. In: Xe congres international des sciences préhistoriques et protohistoriques. Mexico, 195-197. Prague - Brno.

GABRIEL, F.-SMETANA, J., 1980: Sídelně historické aspekty vzniku České Lípy - Siedlungshistorische Aspekte der Entstehung der Stadt Česká Lípa, AH 5, 131-142.

- 1982: K problému existence řemesel na vesnici ve 13. století - Zur Frage der Existenz des dörflichen Handwerks im 13. Jahrhundert, AH 7, 509-516.

- 1983: K vývoji výrobních okruhů červeně malované keramiky v severních Čechách - Zur Entwicklung der Produktionbereiche rot gemalter Keramik in Nordböhmen, AH 8, 119-138.

GABRIEL, F.-PANÁČEK, J., 2000: Dějiny hrnčířství v České Lípě, Bezděz - Vlastivědný sborník Českolipska 9, 5-141.

GAIMSTER, P., 1997: German Stoneware, 1200-1900: Archaeology and Cultural History. London.

GAJEWSKI, L., 1959: Materiały do średniowiecznego garncarstwa wiejskiego w Małopolsce, Materiały archeologiczne I/3, 343-351.

GALUŠKA, L., 2003: Zaniklá hrnčířská pec středověkého Veligradu - Starého Města - důsledek vpádu Matouše Čáka Trenčanského na Moravu roku 1315? - Eingegangener Töpferofen im mittelalterlichen Veligrad-Staré Město (Altstadt) - infolge des Einfalls Matouš Č́k von Trenčín nach Mähren im Jahr 1315?, AH 28, 591-609.

GOŠ, V., 1983: Středověké hrnčířství v Lošticích. Pět let archeologických výzkumů města - Mittelalterliche Töpferei in Loštice. Fünf Jahre archäologischer Untersuchungen, AH 8, 197-209.

GREGEROVÁ, M. a kol., 2010: Petroarcheologie keramiky v historické minulosti Moravy a Slezka. 1. vyd. Brno.

GUADAGNIN, R., 2000: Fosses - Vallée de l'Ysieux, Mille ans de production céramique en Île-de-France. Volume 1: Les données archéologiques et historiques. Caen: Publications du CRAM.

HAVRDA, J.-MATĚJKOVÁ, K., 2014: Hrnčíři ve středověké Praze. Výsledky výzkumu výrobních zařízení z Malé Strany v kontextu dosavadních poznatků - Töpfer im mittelalterlichen Prag. Ergebnisse einer Untersuchung von Produktionsanlagen von der Prager Kleinseite im Kontext der bisherigen Erkenntnisse, AH 39, 23-51.

HAVRDA, J.-MATĚJKOVÁ, K.-TRYML, M., 2012: Středověké pece z Hellichovy ulice na Malé Straně. Revize výsledků výzkumu z roku 1969, Staletá Praha XXVIII, č. 2, 165-174.

HEEGE, A., 1997: A Local Potter's Workshop at Einbeck, Lower Saxony, Germany, Producing from 1140/1145-1230 AD - Kilns, Ceramic Products and Production Technology, Environment and Subsistence: an Interdisciplinary Approach. In: Material Culture in Medieval Europe-Papers of the 'Medieval Europe Brugge 1997' Conference - Volume 7 (De Boe, G.-Verhaeghe, F., edd.), 95-106. Zellik.

- 2007: Einführung in das Thema. In: Töpferofen - Pottery kilns - Fours de potiers. Die Erforschung frühmittelalterlicher bis neuzeitlicher Töpferöfen (6.-20. Jh.) in Belgien, den Niederlanden, Deutschland, Österreich und der Schweiz. Basler H. Arch. 4 (Heege, A., ed.), 11-203. Basel.

- 2009: Töpferöfen im 15./16. Jahrhundert. Innovation oder Stagnation? In: Zwischen Tradition und Wandel. Archäologie des 15. und 16. Jahrhunderts. Tübinger Forschungen zur historischen Archäologie 3 (Scholkmann, B.-Frommer, S.-Vossler, Ch., edd.), 181-190. Büchenbach.

- 2013: Craftsmen's Pottery Kilns in Belgium, The Netherlands, Germany, Austria, and Switzerland. In: Historical Archaeology in Central Europe (Mehler, N., ed.), 279-293. Rockville.

HRDLIČKA, L., 1967: Středověká hrnčířská pec s keramickou klenbou v Bakově nad Jizerou, AR XIX, 511-524.

JANSSEN, W., 1987: Der technische Wandel der Töpferofen von der Karolingerzeit zum Hochmittelalter, dargestellt anhand rheinischer Beispiele. In: La céramique (Ve - XIXe s.) Fabrication - Commercialisation - Utilisation. Ier Congrès International d'Archéologie Médievale, Paris 1985. Actes publiés par la Société d'Archéologie Médiévale avec le concours du Ministère de la Culture et de la Communication, 107-119. Caen.

KALESNÝ, F., 1993: Über die Töpferöfen, ihre Typen und Formen in der Slowakai, Nearchos 1, 165-177 
KALTENBERGER, A., 2009: Keramik des Mittelalters und der Neuzeit in Oberösterreich. Band 1: Grundlagen. Linz.

KÁČERIK, A., 2010: Vrcholně středověká hrnčířská pec s keramickou klenbou v Žatci a její analogie v ČR a zahraničí. In: Zaměřeno na středověk. Zdeňkovi Měřínskému k 60. narozeninám (Ungermann, Š.-Přichystalová, R., edd.), 455-464. Praha.

KAŠPAR, V.-ŽEGKLITZ, J., 2009: Hrnčiřri z Truhlářské ulice. In: Juřina, P. a kol., Náměstí Republiky. Výzkum století, 79-83. Praha.

KLÁPŠTĚ, J., 1998: Die Anfänge der jüngeren mittelalterlichen Keramik in Böhmen als kulturhistorisches Problem - Počátky mladší středověké keramiky v Čechách jako kulturně historický problém, AR L, $138-158$.

KOCK, J., 2004: Medieval pottery kilns in Denmark: Excavation and Reconstruction, Medieval Ceramics $28,3-16$.

KRAJÍC, R., 1982: Výzkum středověké keramické pece v Táboře - Excavation of a medieval pottery kiln at the town of Tábor, AR XXXIV, 269-277.

- 2007: Archeologie postmedieválního období. Současný stav a perspektivy výzkumů v jižních Čechách. In: Archeologie na pomezí. Archeologické výzkumy v jižních Čechách - Supplementum 4, 137-174. České Budějovice.

KWAPIENIOWA, M.-WAŁOWY, A., 1969: Piece garncarskie w świetle badań archeologicznych, Materiały Archeologiczne, tom X, spis treści, 205-228.

LANDSFELD, H., 1950: Lidové hrnčířství a džbánkařství. Praha.

LEHMANN, P., 1992: Zwei Töpferöfen in der Winterthuer Altstadt. In: Berichter der Zürcher Denkmalpflege Archäologische Monographien 12. Zürich.

LÖW-KARPF, L., 1993: Funde aus einem Töpferofen um 1500 im Bamberg, Nearchos 1, 143-154.

MERINGER, R., 1912: Beitrag zur Geschichte der Öfen, Wörter und Sachen - Kulturhistorische Zeitschrift für Sprach- und Sachforschung 3/2, 137-186.

MĚCHUROVÁ, Z.-ZALABÁK, P.-ČEJKA, J., 1992: Př́íspěvek k problematice tzv. loštické keramiky v souvislosti s rentgenovou fázovou analýzou vzorků z Konůvek, ČMZM - Vědy společenské 77, 201-215.

MĚŘÍNSKÝ, Z., 1983: K problematice archeologického výzkumu řemeslné výroby 10. až první poloviny 16. století na Moravě a ve Slezsku - Zur Problematik archäologischer Untersuchungen der handwerklichen Produktion vom 10. bis in die erste Hälfte Jahrhunderts in Mähren und Schlesien, AH 8, 41-71.

MICHNA, P., 1970: Vzájemný vztah pecí chlebových a pecí vyhřívacích na staroslovanských a raně středověkých sídlištích. In: Referáty z I. pracovní porady mladých archeologů. Př́iloha Vlastivědného věstníku moravského č. 3, 68-81. Brno.

MOORHOUSE, a.s., 1981: The medieval pottery industry and its markets. In: Medieval Industry (Crossley, W. D., ed.), 96-125. London.

- 1987: The composition and development of medieval potting tenements in the British Isles. In: La ceramique (Ve-XIXe s.) Fabrication - Commercialisation - Utilisation. Ier Congrès International d'Archéologie Médievale, Paris 1985. Actes publiés par la Société d'Archéologie Médiévale avec le concours du Ministère de la Culture et de la Communication, 179-194. Caen.

MUSTY, J., 1974: Medieval pottery kilns. In: Medieval pottery from excavations. Studies presented to Gerald Clough Dunning (Evison Vera, I.-Hodges, H.-Hurst, J. G., edd.), 41-65. London.

NEKUDA, V., 1963: Nálezy středověkých hrnčířských pecí na Moravě, ČMZM - Vědy společenské XLVIII, 57-84.

- 1978-1979: Mittelalterliche Töpferöfen und Ausbrenntechnik in Mähren, Acta Praehistorica et Archeologica 9-10, 131-133.

NEKUDA, V.-REICHERTOVÁ, K., 1968: Středověká keramika v Čechách a na Moravě. Brno.

OCKLENBURG, U., 1997: Ein spätmittelalterlicher Töpferofen aus Brühl. In: Archäologie im Rheinland, 136-138. Köln - Bonn.

PAJER, J., 1983: Počátky novověké keramiky ve Strážnici. Strážnice.

- 1998: Novokřrtěnci v Ostrožské Nové Vsi, Slovácko 40, 161-182.

- 2001: Novokřtěnské fajánse ze Strachotína. Mikulov.

- 2006: Studie o novokřtěncích. Strážnice.

- 2007: Archaeological excavations of Anabaptist ceramics in Moravia. In: Studies in Post-Medieval Archaeology 2, 227-250. Prague.

PEACOCK, D. M. S., 1982: Pottery in the Roman World. London. 
PÍCKA, J.-TETOUR, M., 2005: Vícov u Přeštic (okr. Plzeň-jih), středověké osídlení při kostele sv. Ambrože - Vícov bei Přeštice (Kr. Pilsen-Süd). Die mittelalterliche Besiedlung bei der St. Ambrosius-Kirche, AVJČ 18, 179-210.

PLICKOVÁ, E., 1959. Pozdišovské hrnčiarstvo. Bratislava.

PREUSZ, M., 2017: Keramika 16. a 1. poloviny 17. století v jižních a západních Čechách. Inovace a kontinuita hrnčířské produkce. Plzeň. Nepubl. dizertační práce, ulož. na KAR FF ZČU v Plzni.

PROCHÁZKA, R., 2015: Mittelalterliche Töpferöfen in Mähren. In: Den Töpfern auf der Spur. Orte der Keramikherstellung im Licht der neuesten Forschung 46. Internationales Symposium Keramikforschung des Arbeitskreises für Keramikforschung und des Römisch-Germanischen Zentralmuseums Mainz vom 16. bis zum 20. September 2013 in Mayen (Grunwald, L., ed.), 215-224. Mainz.

PROCHÁZKA, Z., 1983: Domažličtí hrnčíři na Hořejším předměstí ve 14. a 15. století. Záchranná akce dobrovolného aktivu Muzea Chodska v Domažlicích. Domažlice.

REINFUSS, P., 1960: Piece do wypału naczyń w polskim garncarstwie ludowym, Etnografia Polska 3, 329-349.

RICHTER, M., 1967: Hrnčířské pece v Kostelci nad Orlicí, AR XIX, 500-510.

- 1994: Hrnčířská pec ze Starého Mýta (k otázce počátků vrcholně středověké keramiky). In: Mediaevalia archeologia Bohemica 1993, PA - Supplementum 2, 145-157. Praha.

RICHTER, M.-KRAJÍC, R., 2001: Sezimovo Ústí. Archeologie středověkého poddanského města 2. Levobřežní předměstí - archeologický výzkum 1962-1988. Praha.

SCHARRER, G., 1994: Ein Töpferofen aus Amstetten, NÖ, Beiträge zur Mittelalterarchäologie in Österreich $10,131-150$.

- 2000: Mittelalterliche Töpferöfen im Österreichischen Donauraum und der Strukturwandel in der Keramikherstellung. In: Der keramische Brand. Beiträge zum 32. Internationalen Hafnereisymposion in Bremen vom 27. September bis zum 3. Oktober 1999 (Mämpel, U.-Endres, W., edd.), 69-78. Höhr-Grenzhausen.

- 2001: Mittelalterliche Töpferöfen im österreichischen Donauraum und der Strukturwandel in der Keramikherstellung. In: Beiträge des 4. Treffens des Archäologischen Arbeitskreises zur Erforschung des Mittelalterlichen Handwerks. Medium Aevum Quotidianum 43, 33-97. Krems.

SCHARRER, G.-SCHARRER, P., 2010: Hafner, Händler, Franziskaner. Archäologische Untersuchungen zum Mittelalter in St. Pölten, Niederösterreich. Wien.

SCHEUFLER, V., 1972: Lidové hrnčířství v českých zemích. Praha.

SCHEUFLER, V.-PLICKOVÁ, E., 1966: Lidová hrnčina v Československu. Uherské Hradiště.

SNÁŠIL, R., 1970: Př́íspěvek k technologii černé hrnčiny na Slovácku, ČL 57, 327-335.

STEPHAN, H.-G., 1981: Coppengrave. Studien zur Töpferei des 13. bis 19. Jahrhunderts in Nordwestdeutschland. Materialhefte zur Ur- und Fruhgeschichte Niedersachsens 17. Hildesheim.

STOLL, H. J., 1961: Die mittelalterlichen Töpfereifunde von Sonderhausen/Stockhausen und Weimar, Wagnergasse, Alt-Thüringen 5, 280-377.

TETOUR, M., 2002: Doklady hrnčířské výroby v Horažd’ovicích, okr. Klatovy - Belege der Töpferproduktion in Horažd'ovice, Kr. Klatovy, AVJČ 15, 163-175.

THÉR, R., 2004: Experimental pottery firing in closed firing devices from the Neolithic - Hallstatt Period in Central Europe, EuroREA 1, 35-82.

VARADZIN, L., 2010: Hrnčířská výroba ve východní části střední Evropy 6.-13. století v archeologických pramenech - Pottery production in the eastern part of Central Europe in the 6th to 13th century in archaeological sources, AR LXII, 17-71.

VÁGNER, Z., 2002: Medieval Pottery Kilns in the Carpathian Basin, European Journal of Archaeology 5, 309-342. https://doi.org/10.1179/eja.2002.5.3.309

VAŘEKA, P., 2004: Výrobní (hrnčířský?) areál z časného novověku v Berouně - České ulici čp. 56, AT 15, 78-85.

VOLF, M., 2006: Archeologické doklady vrcholně a pozdně středověké hrnčířské výroby v Čechách. Nepubl. bakalářská práce, ulož. v Ústavu pro pravěk a ranou dobu dějinnou FF UK.

- 2014: Archeologické doklady středověké hrnčířské výroby z Truhlářské ulice v Praze (ze záchranného archeologického výzkumu v areálu bývalých kasáren Jiř́ího z Poděbrad). Nepubl. diplomová práce, ulož. v Ústavu pro pravěk a ranou dobu dějinnou FF UK.

VOLFOVÁ, E.-VOLF, P., 1999: Zpráva o nálezu zbytku hrnčířské pece, PSČ 1, 53-55.

VOTOČEK, O., 1955: Keramické klenby levínských hrnčířů, ZPP 15, 213-214.

VYŠOHLÍD, M., 2015: Hrnčířské předměstí v Berouně: první etapa archeologického výzkumu na parcele ppč. 296 - The Potters' suburb of Beroun: The first stage of the archaeological excavation in land parcel No. 296, ASČ 19, 411-430. 
- 2015a: Hrnčířská pec z 15. století z Hrnčířské ulice v Berouně, Acta FF ZČU 7, č. 2, 155-172.

WEISER, B., 2003: Töpferöfen von 500 bis 1500 n. Chr. im deutschsprachigen Raum und in angrenzenden Gebieten. Bonn.

WINTER, Z., 1906: Dějiny řemesel a obchodu v Čechách v XIV. a v XV. století. V Praze: Nákladem České akademie císaře Františka Josefa pro vědy, slovesnost a umění.

ZATLOUKAL, R., 2000: Archeologické doklady hrnčírsství ve 13. až první polovině 16. stol. na Moravě a ve Slezsku, AT 11, 60-74.

ŽEGKLITZ, J., 1990: Topografie pražských hrnčířských dílen a jejich podoba v 16. - poč. 17. století - The topography and outlook of pottery workshops of Prague in the 16th and incipient 17th Century. In: Studies in Post-Mediaeval Archaeology 1, 215-230. Praha.

- 2015: K počátkům tzv. malhornware v Čechách. In: V za(u)jetí malostranských stratigrafií. Sborník k životnímu jubileu Jarmily Čihákové (Podliska, J., ed.), 110-123. Praha.

\section{Zusammenfassung}

\section{Mittelalterliche und neuzeitliche Töpferöfen in Böhmen - eine kritische Auswertung der Aussagemöglichkeiten von Studien}

Töpferöfen zählen zu den archäologischen Funden, welche eine direkte Keramikproduktion belegen. In Böhmen wurde im Unterschied zu Mähren und den Nachbarländern den Funden von Töpferöfen keine ausreichende Aufmerksamkeit gewidmet. Der vorliegende Beitrag ist ein Versuch, die in den Zeitraum des 13.-16./17. Jahrhunderts datierten in Böhmen gemachten Funde mittelalterlicher und neuzeitlicher Öfen auszuwerten. Beurteilt wird die gesamte Form des Aufbaus der Öfen und ihre typologische und funktionelle Klassifikation. Die traditionelle Typologie schuf eine Klassifikation der Öfen nach dem Kriterium, ob die Feuerung vom Brennraum getrennt war, wobei die thermodynamischen Eigenschaften unberücksichtigt blieben, zu denen die Art der Flammenführung in vertikaler, horizontaler oder diagonaler Richtung im Ofen gehört. Erst auf Grundlage von ausländischen Arbeiten aus vor allem der deutschsprachigen Umgebung kam es durch Verdienst von R. Procházka zu einer Neubewertung und Neuinterpretation einiger Funde von mährischen Öfen. In Böhmen versuchen wir, eine ähnliche Typologie zu schaffen. Als Grundlage wurde die Schaffung eines detaillierten deskriptiven Systems und einer Datenbank mit Keramikbrennöfen herangezogen. Ausgangsbasis ist dabei der Stand der Geländedokumentation und Beschreibung der Fundsituationen, die bei einigen Ofenbeispielen unzureichend ist. Eine Reihe von Funden wurde bislang nicht detailliert veröffentlicht, und bei einer Reihe von Beispielen vermissen wir eine Schnittdarstellung, d.h. das Profil der Öfen in ihrer ganzen Länge, die wir im Hinblick auf eine richtige typologische Einordnung als grundlegend ansehen. Die meisten Ofenfunde wurden bei archäologischen Rettungsgrabungen zufällig gemacht oder waren beträchtlich gestört, und bis auf Ausnahmen (Česká Lípa, Sezimovo Ústí, Prag - Neustadt, Platz der Republik, Beroun) vermissen wir systematische Freilegungen ganzer Töpferarbeitsstätten, an denen neben den Töpferöfen Funde von Scherben, Töpferohstoffdeponien und Lagerplätze fertiger Erzeugnisse eine Keramikproduktion belegen. Gegenüber den Töpferofenfunden in Mähren, aber auch woanders in Westeuropa, begegnen wir in Böhmen Öfen mit einfacheren Konstruktionsvarianten. Im Falle der Keramikbrennöfen aus Böhmen hat sich eine Entwicklung gezeigt, die nach und nach von vertikalen Einkammeröfen in Richtung horizontaler Einkammeröfen und zu Öfen mit diagonalem Flammenzug geht.

Vertikale Einkammeröfen zählen zu den ältesten archäologisch belegten Töpferofentypen in Böhmen. Der älteste stammt vom Beginn des 13. Jahrhunderts, wenn man bisher nicht entdeckte Belege für Grubenbrand oder sog. Meileröfen mal außer Acht lässt. Vertikale Einkammeröfen waren in Böhmen während des ganzen 13. und 15. Jahrhunderts verbreitet und tauchten auch noch an der Wende des 16. und 17. Jahrhunderts auf. Bei spätmittelalterlichen Öfen kam es zu einer Änderung der Bauweise, als Lehmöfen durch Konstruktionen aus beständigeren Materialien (Steine und Ziegelsteine) ersetzt wurden. Im jüngeren Horizont des 16. bis 17. Jahrhundert hatten die Öfen bereits eine Fundamentkonstruktion, einen Boden und Wände aus Ziegelsteinen (die jüngsten 
Beispiele für vertikale Einkammeröfen sind die Öfen aus Beroun und Tábor). Horizontalen Einkammeröfen begegnet man in Böhmen bereits ab Ende 13. und Anfang 14. Jahrhundert, und erst im 15. Jahrhundert kommt es zu ihrer hauptsächlichen Verbreitung. Während dieser Zeit kommt es zu einer langsamen Zunahme ihrer Größe, offenbar aus dem Bedürfnis, eine größere Kapazität und eine umfangreichere Keramikproduktion zu erzielen. Bei einer weiteren Untersuchung bleibt die Frage, inwieweit kulturelle Kontakte bzw. ein Technologietransfer und die Einführung von Innovationen in der Produktion an ihrer Verbreitung beteiligt waren. Die ältesten Beispiele für Böhmen sind, mit Ausnahme des atypischen Ofens Nr. 3 aus Kostelec nad Orlicí, mit der Produktion von rotbemalter Keramik verbunden (Česká Lípa, Prag - Kleinseite). Horizontale Einkammeröfen können wir in zwei Grundtypen unterteilen, und zwar in Öfen mit nicht gegliedertem Boden und in Öfen, bei denen die Feuerung deutlicher eingetieft ist als der Brennraum und von der Ofenkammer durch einen Sockel abgetrennt wird. Diese Öfen, die darüberhinaus noch in einem Hang eingetieft waren, ermöglichten eine diagonale Flammenführung. Zu ihrer Verbreitung kam es erst im 15. Jahrhundert.

In Böhmen fehlen nachweislich Belege für Zweikammeröfen, für die eine Abtrennung mittels eines vertikalen oder horizontalen Rostes charakteristisch ist. Eine Ausnahme stellt vielleicht der Ofen mit Mittelzunge aus Vícov u Přeštic dar, der seiner Grundrissform nach ähnlichen Ofentypen aus Mähren oder Österreich vergleichbar nahe steht. Ein seltenes Beispiel ist der horizontale Einkammerofen aus Kostelec nad Orlicí (Ofen Nr. 3), bei dem der Feuerungsraum und der Brennraum durch eine Trennwand aus Lehm, die vergleichbare Analogien in Deutschland hat, getrennt sind. In Böhmen tauchen im Unterschied zu Mähren mehr Öfen mit einer Keramikkuppel auf, und zwar nur bei horizontalen Einkammeröfen. Eine bisher ungeklärte Frage bleibt, ob die mit ihrer Nutzung verbundenen Töpfe in der Kuppelkonstruktion der Öfen nicht auch anders im Rahmen der Brennkammer funktionieren konnten, etwa nach Art sog. Mäntel, wie wir es von der Ethnographie her kennen, oder ob sie nicht eine Mittelsäule (Zunge) als Fundament für irgendeine Form eines mobilen Rostes haben bilden können. Nur in Einzelfällen (Prag - Neustadt, Platz der Republik, wohl auch Bakov nad Jizerou) verfügen wir bei horizontalen Einkammeröfen oder Öfen mit diagonaler Flammenführung über Belege für die Unterteilung des Innenraums durch Mittelsäule aus Lehmquadern oder Ziegelsteinen (sog. Ständer), deren Funktion auf einer Flammenführung von bis zu zwei und mehr Zügen basiert.

Einkammeröfen mit diagonaler Flammenführung, wenn die Feuerung gegenüber der Ofenkammer deutlich eingetieft ist und durch einen Sockel getrennt wird, können wir als Entwicklungsvorstufe zu den neuzeitlichen Öfen vom Kasseler Typ verstehen. In Böhmen kam es bislang noch zu keiner Entdeckung der jüngsten Ofengruppe, zu welcher in der westeuropäischen Terminologie neben Öfen vom Kasseler Typ auch der Typ Piccolpasso zählt. Diese Öfen hängen allerdings mit der Herstellung von Steingut und Fayancen zusammen, die in Böhmen höchstwahrscheinlich nicht hergestellt wurden und als Fertigprodukte aus den Produktionszentren für Steingut dorthin importiert wurden, vor allem aus Sachsen und der Lausitz, bzw. was Fayancen betrifft aus Südmähren.

Die vorliegende Studie ist ein Ergebnis des Förderprojektes NAKI II - Hochmittelalterliche Keramik als Bestandteil des mobilen kulturellen Erbes, Projektnr. DG18P02OVV020.

Mgr. Ladislav Čapek, Ph.D., Katedra archeologie Filozofické fakulty Západočeské univerzity v Plzni, Sedláčkova 15, 30614 Plzeň, Česká republika, capekla@kar.zcu.cz

Mgr. et Mgr. Michal Preusz, Ph.D., Katedra archeologie Filozofické fakulty Západočeské univerzity v Plzni, Sedláčkova 15, 30614 Plzeň, Česká republika,preusz@kar.zcu.cz 
